\title{
WestVirginiaUniversity
}

THE RESEARCH REPOSITORY @ WVU

Graduate Theses, Dissertations, and Problem Reports

2005

\section{Water quality disturbances in an aquaculture that utilizes treated mine water}

Mark Wayne Smith

West Virginia University

Follow this and additional works at: https://researchrepository.wvu.edu/etd

\section{Recommended Citation}

Smith, Mark Wayne, "Water quality disturbances in an aquaculture that utilizes treated mine water" (2005). Graduate Theses, Dissertations, and Problem Reports. 1648.

https://researchrepository.wvu.edu/etd/1648

This Thesis is protected by copyright and/or related rights. It has been brought to you by the The Research Repository @ WVU with permission from the rights-holder(s). You are free to use this Thesis in any way that is permitted by the copyright and related rights legislation that applies to your use. For other uses you must obtain permission from the rights-holder(s) directly, unless additional rights are indicated by a Creative Commons license in the record and/ or on the work itself. This Thesis has been accepted for inclusion in WVU Graduate Theses, Dissertations, and Problem Reports collection by an authorized administrator of The Research Repository @ WVU. For more information, please contact researchrepository@mail.wvu.edu. 
Water Quality Disturbances in an Aquaculture That Utilizes Treated Mine Water

Mark Wayne Smith

Thesis submitted to the

College of Engineering and Mineral Resources

at West Virginia University

in partial fulfillment of the requirements

for the degree of

Master of Science in Engineering

Area of Emphasis:

Civil and Environmental Engineering

Roger C. Viadero, Jr., Ph.D., Chair

Kenneth Semmens, Ph.D.

John Zondlo, Ph.D.

Department of Civil and Environmental Engineering

Morgantown, West Virginia

2005

Keywords: Aquaculture, Treated Mine Water, Feed Conversion Ratio,

Water Quality Disturbance, Aeromonas, HAZOP Analysis

Copyright 2005 Mark W. Smith 


\begin{abstract}
Water Quality Disturbances in an Aquaculture That Utilizes Treated Mine Water Mark W. Smith
\end{abstract}

The objectives of this study were to compare the performance of two feed treatments on a population of rainbow trout, Oncorhynchus mykiss, reared in a linear raceway system, which utilized mine water from a mine water treatment facility (MWTF); to measure and compare waste outputs; to monitor the water quality of the system; and to identify the impacts, if any, of the water quality on the fish population. Toward the end of the study, a spike in the turbidity of the water source led to additional objectives. First, the water quality was characterized during the events to determine the extent of the disturbance. Second, the impact of the events on the health and growth of the fish was evaluated. Next, the vulnerability of aquaculture systems that utilize mine waters to such events was addressed. Finally, additional water quality treatment options were identified and preliminary designs were completed.

Weekly field monitoring of the water quality included measuring temperature, $\mathrm{pH}$, salinity, specific conductance, dissolved oxygen, turbidity, and flow rate. Monthly water quality testing consisted of analysis of grab samples for acid mine metals, nutrients, sulfates, suspended solids, acidity, and alkalinity. Monthly fish sampling consisted of measuring the length and weight of a randomly collected sample of at least fifty fish from each raceway section.

The two feed treatments in this study were Ziegler Gold and Freedom Feed VegiProß, which has an all vegetable based protein source. The population fed the Ziegler Gold diet had a better feed conversion ratio than the population fed the VegiPro ${ }^{\circledR}$. However, the fish fed the Ziegler diet also produced a greater amount of waste. Finally, there was no significant difference in the cost of feeds based on the amount of mass gained by each system. 
The water quality disturbances resulted in an outbreak of an aeromonas infection, which caused a significant number of mortalities. The disturbance was attributed to upstream modifications in the MWTF. The analysis of the vulnerability of the system to such water quality upsets resulted in the design of a suspended solids filtration system, an ionic exchange system for metals removal, and a diffused air supplied aerator. The ionic exchange system was proved to be impractical and too costly for the current operation. Implementation of the filtration unit and aeration system is recommended. 


\section{DEDICATION}

First, this thesis is dedicated to my Lord and Savior, Jesus Christ; second, to my lovely wife, Kristin, and my new, baby boy, Aidan. You are my “reason.” I love you.

I also owe much to my family - Mom, Dad, and my brother, Tim - for all of their support throughout my life, and their encouragement throughout my academic career. 


\section{ACKNOWLEDGEMENTS}

First, I would like to thank Dr. Roger C. Viadero, Jr., for his guidance, support, and infinite patience throughout the completion of my research. Having him as my research advisor and thesis committee chair has been a most valuable experience and a tremendous opportunity for me to develop as a researcher, a professional, and as a person. I would also like to thank the other members of my thesis committee: Dr. Kenneth Semmens, for his aquaculture expertise and valuable insight into the bigger picture of my research project; Dr. John Zondlo, first, for his guidance in my undergraduate degree in Chemical Engineering, and now for his input and support in my thesis. Additionally, a special thanks to Ms. Aislinn Tierney for all her help and instruction, especially for getting the aqua-sludge grab samples.

I would like to acknowledge West Virginia University: the College of Engineering and Mineral Resources, the Davis College of Agriculture, Forestry, and Consumer Sciences, the Chemical Engineering Department, the Civil and Environmental Engineering Department, and the Department of Agriculture and Natural Resources. I would also like to acknowledge the United States Department of Agriculture.

Finally, a special thanks to my family at Chestnut Ridge Church for their prayers, support, and spiritual guidance. 


\section{TABLE OF CONTENTS}

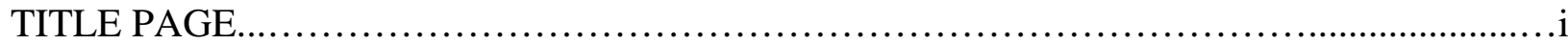

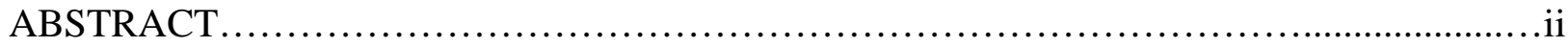

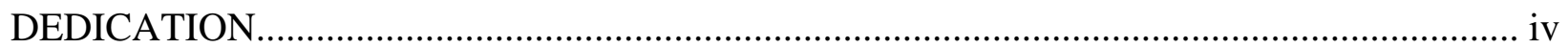

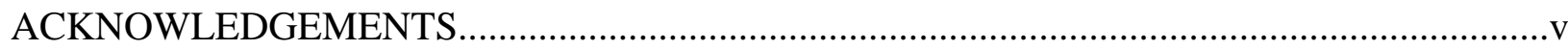

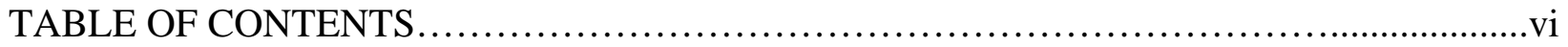

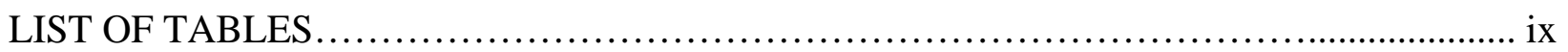

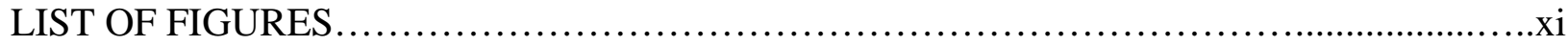

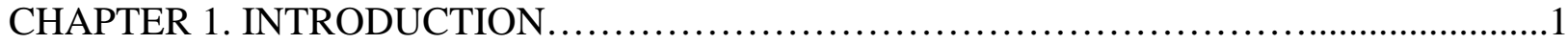

1.1 Problem Statement .......................................................... 1

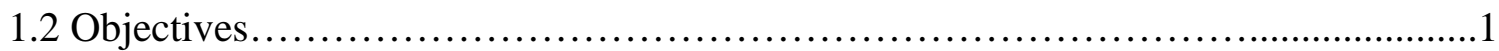

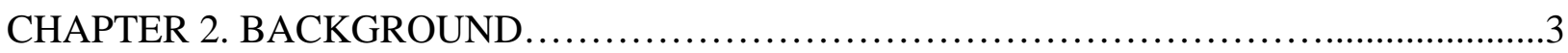

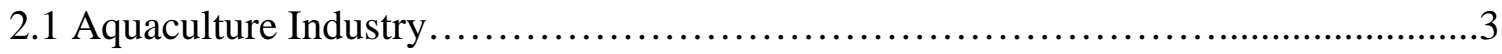

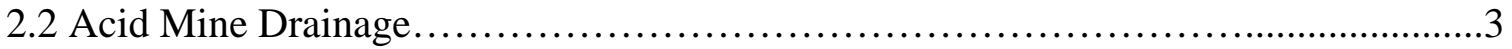

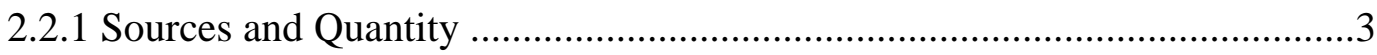

2.2.2 Treatment Process ..............................................................................

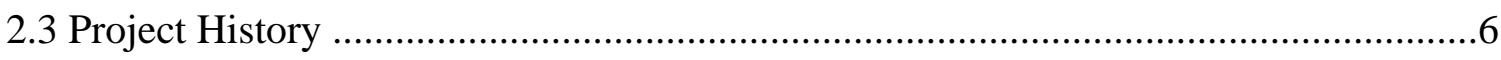

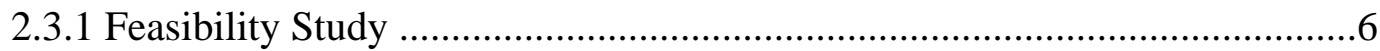

2.3.2 Year 1 - Production Scale Process .........................................................

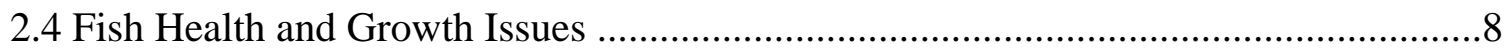

2.4.1 Factors Affecting Fish Health ................................................................8

2.4.2 Indicators of Health Issues ..............................................................13

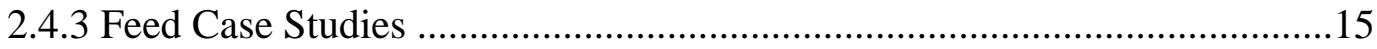


CHAPTER 3. INVESTIGATIVE APPROACH

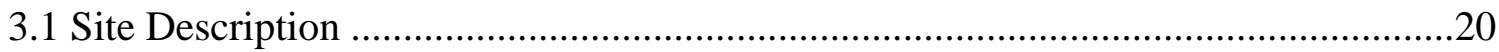

3.2 Raceway Stocking ................................................................................................23

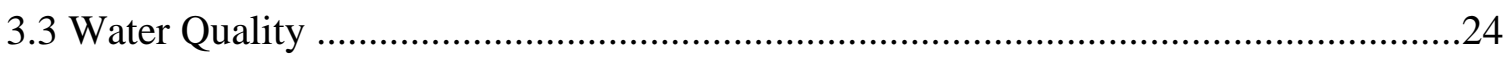

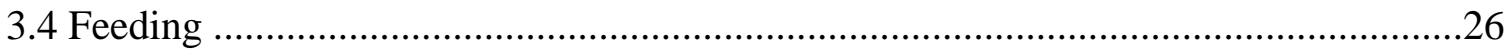

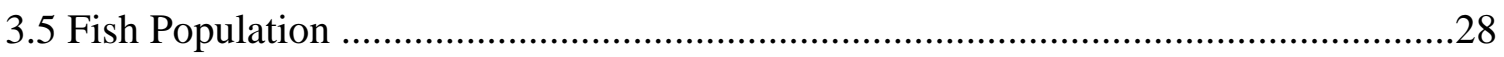

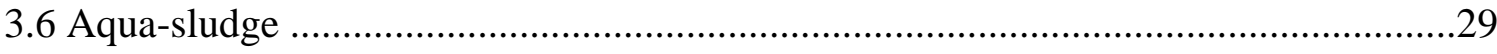

3.7 Quality Assurance and Quality Control ....................................................................29

3.8 Statistical Analysis ..............................................................................................31

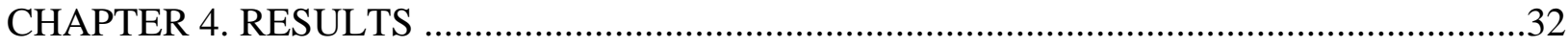

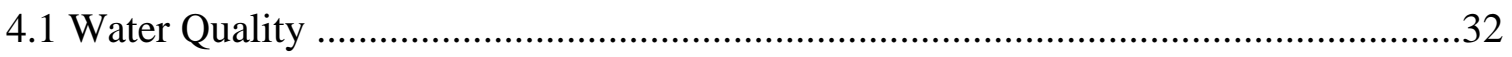

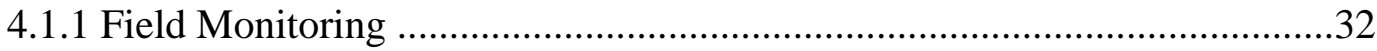

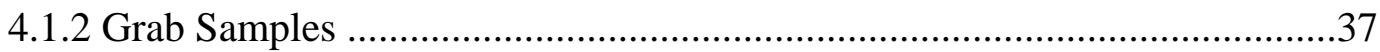

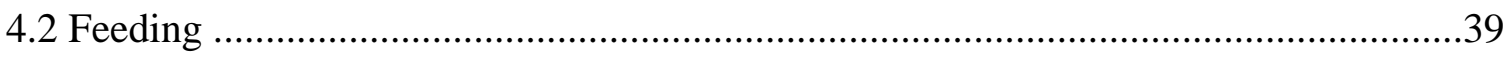

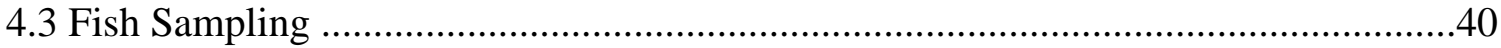

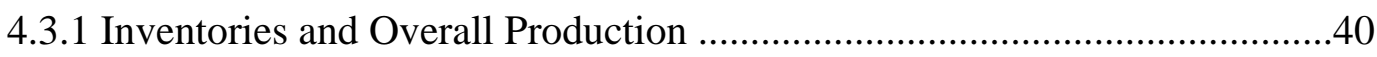

4.3.2 Length ......................................................................................................

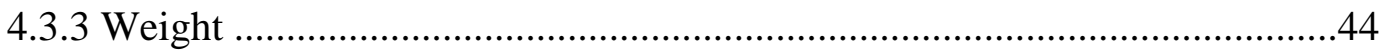

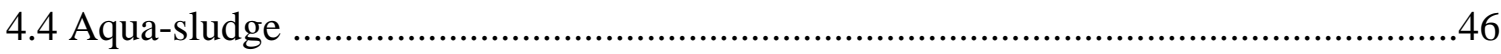

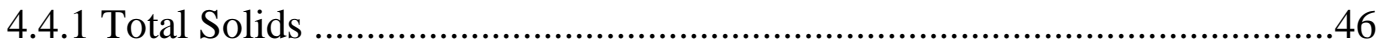

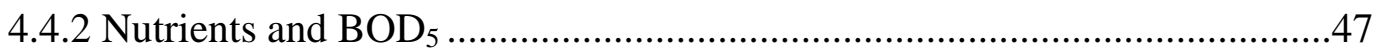

4.5 Water Quality Disturbance Events ............................................................................48 


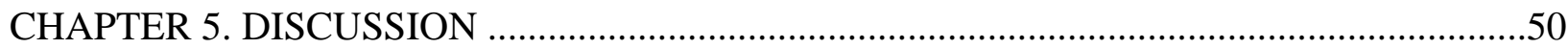

5.1 Feed Comparison - Before Disturbance Events ……………………….......................50

5.1.1 Water Quality ............................................................................................50

5.1.2 Feed Conversion .............................................................................................50

5.1.3 Waste Production ......................................................................................51

5.2 Impact of Disturbance Event ...................................................................................53

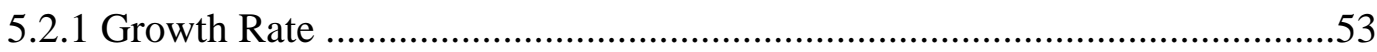

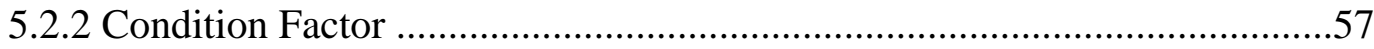

5.2.3 Disease and Mortalities ..........................................................................58

5.3 System Risk Assessment ...................................................................................62

5.4 Back-up Treatment Process Design .............................................................................66

5.4.1 Solids Filtration Unit ..................................................................................66

5.4.3 Ionic Exchange Unit ...........................................................................68

5.4.4 Aeration System ......................................................................................69

CHAPTER 6. CONCLUSIONS AND RECOMMENDATIONS ................................................71

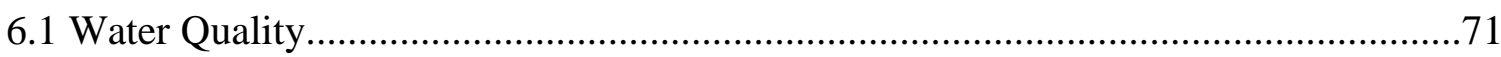

6.2 Feed Conversion................................................................................................

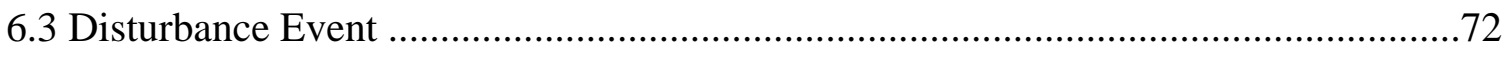

6.4 Back-up Treatment Units ......................................................................................72

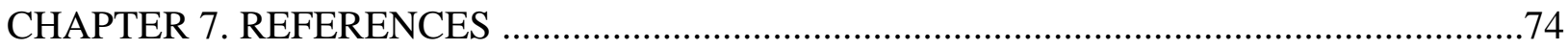

APPENDIX A - Works Consulted ……………………...........................................................

APPENDIX B - Data Tables ................................................................................................. 78

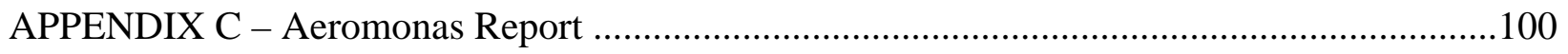




\section{LIST OF TABLES}

TABLE

PAGE

Table 2.1 Water Temperature Ranges. $\quad 9$

$\begin{array}{lll}\text { Table } 2.2 \text { Water Quality Requirements. } & 10\end{array}$

$\begin{array}{lll}\text { Table } 2.3 & \text { Dietary Content of Two Feed Sources. } & 16\end{array}$

Table 2.4 Experimental Conditions for Feed Case Study. 16

Table 2.5 Comparison of Experimental Parameters for Feed Case Study. $\quad 17$

Table 2.6 Final Results of Study Comparing Three Diets. 18

$\begin{array}{lll}\text { Table } 2.7 & \text { Results of Feed Analyses on Three Separate Diets. } & 18\end{array}$

Table 3.1 Summary of Field Monitoring and Grab Sampling Schedule. 25

Table 3.2 Summary of Instrumentation Used for Field Monitoring and 25

Grab Sample Analysis.

Table 3.3 Summary of Laboratory Methods Used for Grab Sample Analysis. $\quad 26$

Table 4.1 Field Monitoring Data Summary of Insignificantly Varying 32

Parameters.

Table 4.2 Grab Sample Data Summary. $\quad 37$

Table 4.3 Grab Sample Nutrient Data Summary. 38

Table 4.4 Grab Sample Metals Data Summary. 39

Table 4.5 Summary of Total Feed Supplied to Each Raceway. $\quad 40$

Table 4.6 Summary of Inventory Results from Stocking to Harvesting 41

- Total Mass.

Table 4.7 Summary of Inventory Results from Stocking to Harvesting - Population.

Table 4.8 Overall Summary of System Performance and Production. 
Table 4.9 Summary of Nutrient Content and $\mathrm{BOD}_{5}$ of Aqua-sludge Samples. $\quad 47$

Table 4.10 Summary of Water Quality Disturbance Values. $\quad 48$

Table 4.11 Summary of Water Quality Disturbance Total Metal Concentrations. $\quad 49$

Table 5.1 Summary of Mass Balance Calculations. 53

Table 5.2 HAZOP Risk Analysis on MWTF Aquaculture System 65

Table 5.3 Microscreen Filtration System Design and Cost Summary. $\quad 67$

Table 5.4 Summary of Water Conditions for Treatment in Ionic Exchange $\quad 68$ Column.

Table 5.5 Summary of Ionic Exchange Treatment System and Cost $\quad 69$ Estimates

$\begin{array}{lll}\text { Table } 5.6 & \text { Summary of Aerator Design } & 70\end{array}$

$\begin{array}{lll}\text { Table } 5.7 & \text { Summary of Aerator Cost } & 70\end{array}$ 


\section{LIST OF FIGURES}

FIGURE

PAGE

Figure 2.1 Flow Diagram of Mine Water Treatment Process. $\quad 4$

Figure 2.2 Photograph of Acid Mine Water Aerator. 4

Figure 2.3 Photograph of Hydrated Lime Storage Vessels. 5

Figure 2.4 Photograph of Solids Settling Pond. 5

Figure 2.5 Diagram of Disease Outbreak Conditions 9

Figure 3.1 Profile View of Single Raceway Unit Design. 20

Figure 3.2 Single Raceway Unit Dimensions and Connection of Quiescent Zone. 21

Figure 3.3 Plan View of One Stage of Raceway Units. 22

Figure 3.4 Plan View of All Four Stages of Raceway System. 22

Figure 3.5 Photograph of the First Raceway Section at the Research Site. 23

Figure 3.6 Water Sampling Sites for All Raceway Units. $\quad 24$

Figure 3.7 Diagram of Demand Figure Installed in Each Raceway. $\quad 27$

Figure 3.8 Photograph of Demand Feeders Installed on Each Raceway. 28

Figure 4.1 Field Monitoring Temperature Measurements. 33

Figure 4.2 Field Monitoring Dissolved Oxygen Measurements. 34

Figure 4.3 Effects of Temperature and Fish Growth on Dissolved Oxygen. 35

Figure 4.4 Field Monitoring Turbidity Measurements. 36

Figure 4.5 Sondes Meter Turbidity Measurements 37

Figure 4.6 Comparison of Sampled Fish Length Between Two Feed Sources. 43

Figure 4.7 Comparison of Length Increase Between Two Feed Sources. 44

Figure 4.8 Comparison of Sampled Fish Weight Between Two Feed Sources. 45 
Figure 4.9 Comparison of Fish Growth Rate Between Two Feed Sources. 46

Figure 4.10 Comparison of Solids Produced for Two Feed Sources $\quad$. 47

Figure 5.1 Growth Rate (Mass) Comparison for Two Feeds with Changing 54 Temperature.

Figure 5.2 Growth Rate (Length) Comparison for Two Feeds with Changing 55 Temperature.

Figure 5.3 Growth Rate (Length) Comparison for Temperature Unit Model 56 Prediction.

Figure 5.4 Growth Rate (Mass) Comparison for Temperature Unit Model 57 Prediction Using K.

Figure 5.5 Comparison of Condition Factor Between Two Feed Sources. 58

Figure 5.6 Photograph of Fish Infected by Aeromonas Bacteria. 59

Figure 5.7 Plot of Cumulative Mortalities after Disturbance Events. 60

Figure 5.8 Plot of Increasing Rate of Mortalities per Day. 61

Figure 5.9 Diagram of Rotating Drum Microscreen Filtration System Design. $\quad 67$ 


\section{CHAPTER 1. INTRODUCTION}

\subsection{Problem Statement}

With current growth trends in the aquaculture industry worldwide and with increasing market interest in Appalachian regions of the United States, greater utilization of water resources and optimized operation of fish rearing facilities is critical. Requirements include sufficient water quantity and quality, improved waste management, proper fish health maintenance, and growth rate enhancement through appropriate selection of dietary sources. Due to its abundant source of treated mine waters capable of sustaining healthy aquaculture operations, as well as its advantageous topography, West Virginia has emerged in recent years as a viable location for significant development of fish rearing facilities.

\subsection{Objectives}

The initial objectives of this research were to (1) monitor the water quality and waste generation of a production-scale rainbow trout, Oncorhynchus mykiss (Kamloops strain), rearing facility operated with treated mine water; (2) identify the impact, if any, of water quality on the system performance; (3) compare growth rate, feed conversion, and waste production of two systems with different feed treatments; (4) evaluate the potential for cost savings and waste reduction through alternative dietary options. To accomplish these objectives, a literature survey of aquaculture operation guidelines and case studies was conducted; regular water quality assessment through field monitoring and grab sample analysis was performed; waste generation was measured through aquasludge sampling; growth and survival rates were determined from monthly fish sampling; and feeding rates and methods were tracked.

As a result of two unforeseen system disturbances late in the season, several additional objectives were later incorporated, and consequently became the central focus of this report. 
These new objectives were to (5) identify the impact of the disturbances on the fish health and growth rates; (6) discuss the possibility that although rainbow trout have been successfully reared in treated mine waters in previous studies and other facilities, their health condition could be more fragile than fish raised in natural streams causing them to be more susceptible to infectious diseases; (7) assess the factors leading to the increased vulnerability of aquaculture systems that utilize treated mine water resources to such disturbances; and (8) propose methods to minimize the impact on and the risk of harm to fish in such operations. To accomplish this set of objectives, additional literature was reviewed, an investigation into the cause of the disturbances was conducted, and design calculations for back-up treatment systems were performed. 


\section{CHAPTER 2. BACKGROUND}

\subsection{Aquaculture Industry}

Aquaculture is a growing industry worldwide yielding \$800 million to \$1 billion annually in the United States alone. Several states that are pursuing a significant increase in this industry include Alabama, Arkansas, Delaware, Hawaii, Louisiana, Mississippi, and West Virginia. West Virginia has great potential for development of this industry because of its abundance of reusable water sources and its topography. A major water resource for potential utilization in the aquaculture industry in West Virginia is treated acid mine waters.

\subsection{Acid Mine Drainage}

\subsubsection{Source and Quantity}

Every year, billions of gallons of mine water are pumped, treated, and discharged into local streams by coal mine companies in West Virginia under the National Pollutant Discharge Elimination System (NPDES). As both active and abandoned mines are pumped, they are constantly recharged by precipitation and groundwater requiring continuous treatment operations. Recent research has determined that the quality of treated mine water (TMW) is sufficient to sustain aquaculture systems used to rear rainbow trout, Oncorhynchus mykiss (Viadero and Tierney, 2003).

A study conducted by the Conservation Fund's Freshwater Institute determined that there are 125 mines in the state of West Virginia that treat and discharge enough water to sustain an economically profitable aquaculture facility (Heinen). These treated waters are perhaps the largest and most underutilized water resources in the state. 


\subsubsection{Treatment Process}

The treatment process first requires pumping mine water up to the ground surface. The water is then aerated and hydrated lime is added to raise the $\mathrm{pH}$. The result of this step is the precipitation of metals present in the water. The slurry of precipitated metals, mainly iron oxide, $\mathrm{Fe}_{2} \mathrm{O}_{3}$, and water then flows to a settling basin, or pond, where the metal oxides settle to the bottom of the reservoir before reaching the outlet. The water at the outlet is then discharged to a local stream under the NPDES. Prior to discharge, it is possible to utilize the treated water to create an aquaculture. Figure 2.1 is a flow diagram of the treatment process.

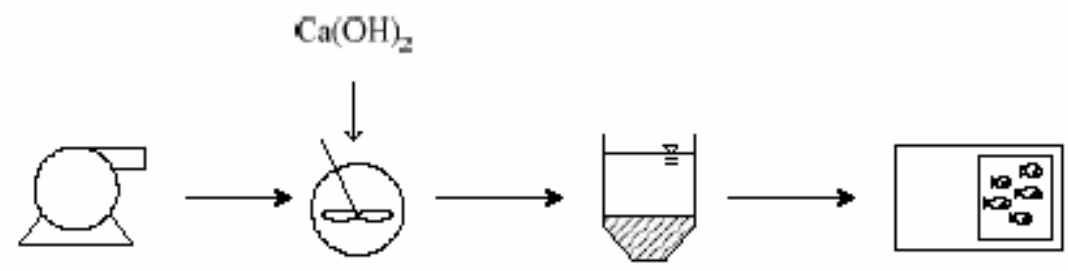

Figure 2. 1 Flow Diagram of Mine Water Treatment Process.

Figure 2.2 is a photograph of the aerator used to increase the oxygen content of the water during treatment.

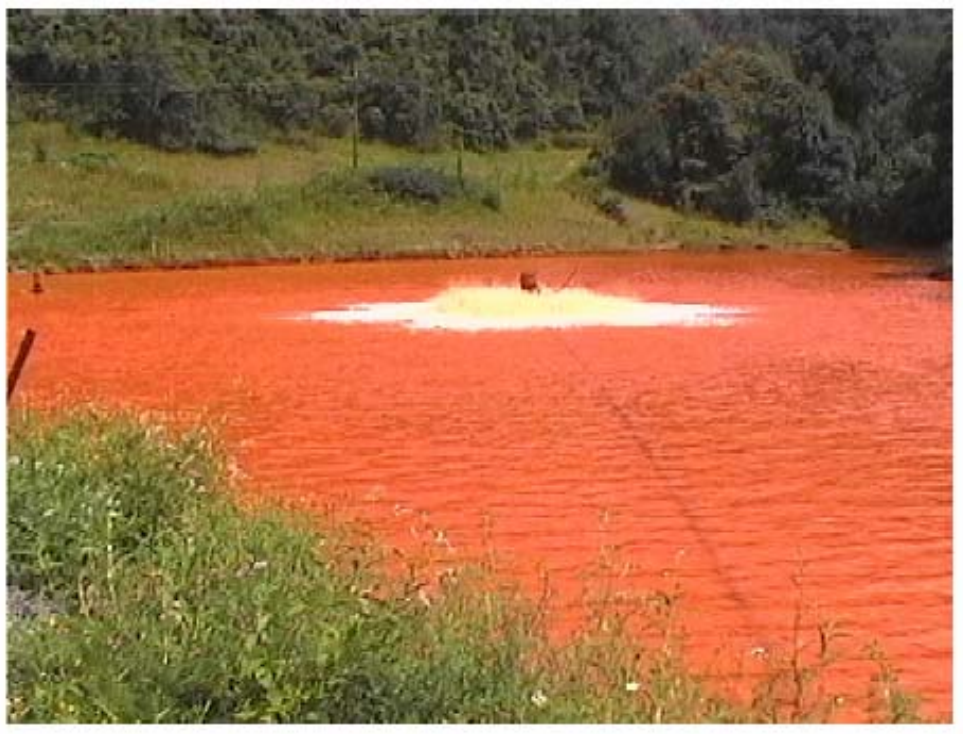

Figure 2.2 Photograph of Acid Mine Water Aerator. 
Figure 2.3 is a picture of the vessels containing the hydrated lime that is added to the water to neutralize the acid.

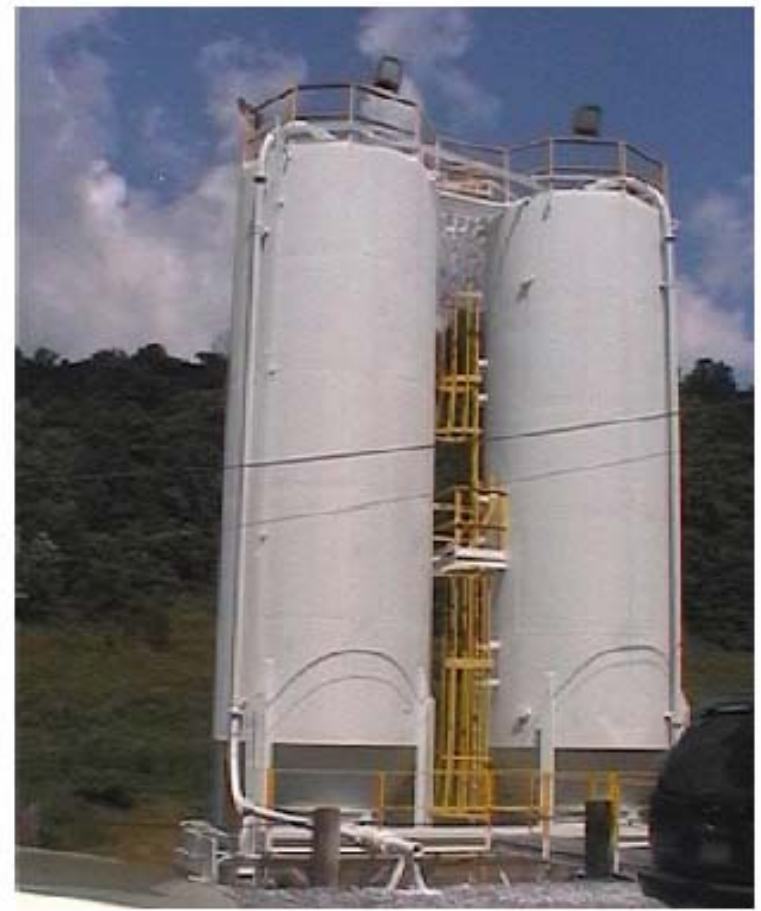

Figure 2.3 Photograph of Hydrated Lime Storage Vessels.

Figure 2.4 is a photograph of the settling pond where the precipitated metal oxides settle out by gravity before the water is sent to the aquaculture system or to a local stream.

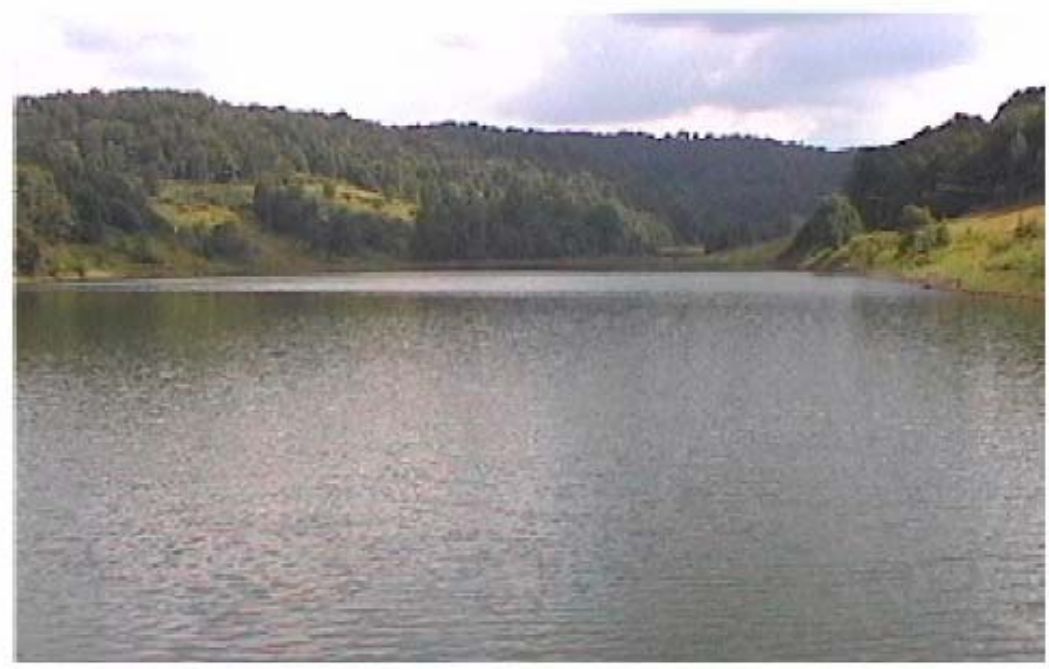

Figure 2.4 Photograph of Solids Settling Pond. 


\subsection{Project History}

\subsubsection{Feasibility Study}

\subsubsection{Problem Statement}

In the first year of research, a preliminary study was conducted to determine the technical feasibility of utilizing treated mine water to support an aquaculture facility to raise rainbow trout, Oncorhynchus mykiss. The site selected was Dogwood Lake and is located in Monongalia County, West Virginia. Although it was known that other facilities in the region were operating successfully with similar water sources, no peer reviewed data had been reported. Therefore, the objectives established were to gather a body of water quality data for an entire rearing season at the proposed site; characterize the water chemistry of treated acid mine drainage (AMD); place a test population of 50 rainbow trout in the water; monitor the fish health and growth; perform a metal body burden analysis to determine if the fatty tissue of the test population absorbed any of the metal in the water to an unsafe level.

\subsubsection{Results and Conclusions}

The study yielded positive results and it was concluded that the treated mine water was indeed a viable water source for raising trout and other salmonids in an aquaculture system. The anticipated, negative impacts of the water quality on the test population were not observed. This finding was attributed largely to the high ionic strength of the water system. Additional data is reported by Tierney (2002). Along with the data, a review of literature on the abundance of such water resources in the state of West Virginia, and an analysis of the potential economic benefits of increasing the aquaculture industry gave strong support for continuing the study effort. A linear raceway system was designed and installed at the water source for a production scale research effort the following season. 


\subsubsection{Year 1 - Production Scale Process}

\subsubsection{Problem Statement}

The second year of this project was Year 1 of the scaled up system. To further the study of using treated mine water to rear trout, the research was expanded to develop an intensive production scale process containing 8000 rainbow trout in a linear flow-through raceway system. This 9 month study included continued water quality data collection as well as monthly sampling of the fish to monitor health and growth rates. Detailed experimental design information is contained in literature by Viadero et al. (2004).

\subsubsection{Results and Conclusions}

Similar to the preliminary investigation, the fish in this study grew well in the treated mine water raceway system. The overall feed conversion ratio was calculated to be 1.4 and a condition factor of $5.1 \times 10^{-4}$ was measured. The total net production was $3275 \mathrm{~kg}$ (7220 lb) and a survival rate of $98.6 \%$ was observed. The growth rate of the system was $1.52 \mathrm{~g} /$ day. More detailed data, including water quality, are presented in the previously cited publication.

Along with these results, several items were identified for continuation of the research effort. Elevated ammonia levels resulting from the upstream treatment process were identified as a future area of concern and a potentially limiting factor. Also, the sulfate concentration was 4 times the recommended level. Presently, the effects of these issues have been reduced by the $\mathrm{pH}$ and the high ionic strength of the water. Additionally, metal ion concentrations, without the benefit of the ionic strength, remain above recommended limits. Further discussion of the metal speciation is also provided.

No statistically significant difference in growth rate was observed between the two feeds used in the study. This was expected, however, since the fat and protein contents of both were 
similar. Overall the growth rates observed were promising. When compared to a predictive growth model, Forecast (Thompson, 2003), all sections remained between the default and maximum expected growth, with the exception of the mixed gender population, which demonstrated the lowest growth rate. This could be explained by a non-aggressive feeding schedule and quantity; for the mixed gender section, the low growth rate was attributed to energy spent on reproductive processes.

Overall, the effort was determined to be a success based on production results. Further studies for the utilization of treated mine water for intensive production of rainbow trout in flowthrough systems was recommended as an opportunity to develop a value-added use of this water source.

\subsection{Fish Health and Growth}

\subsubsection{Factors Affecting Fish Health}

Wedemeyer (2001) identifies four major environmental factors related to maintaining fish health and preventing disease in intensive aquaculture systems: water quality, handling and transporting, nutrition, and sanitation. Significant deficiencies or variations in these parameters raise the already elevated stress level of these crowded and immobile fish populations causing their defense and immune systems to be compromised and more susceptible to reduced health and growth.

Figure 2.5 is a diagram of the conditions that are necessary for an outbreak of a disease to occur. All three elements must be present at the same time as shown by the shaded overlapping section. The host is the fish population, the pathogen is any virus, fungus, or bacteria that can cause an infection, and the environment is any unfavorable external condition mentioned in the previous paragraph. 


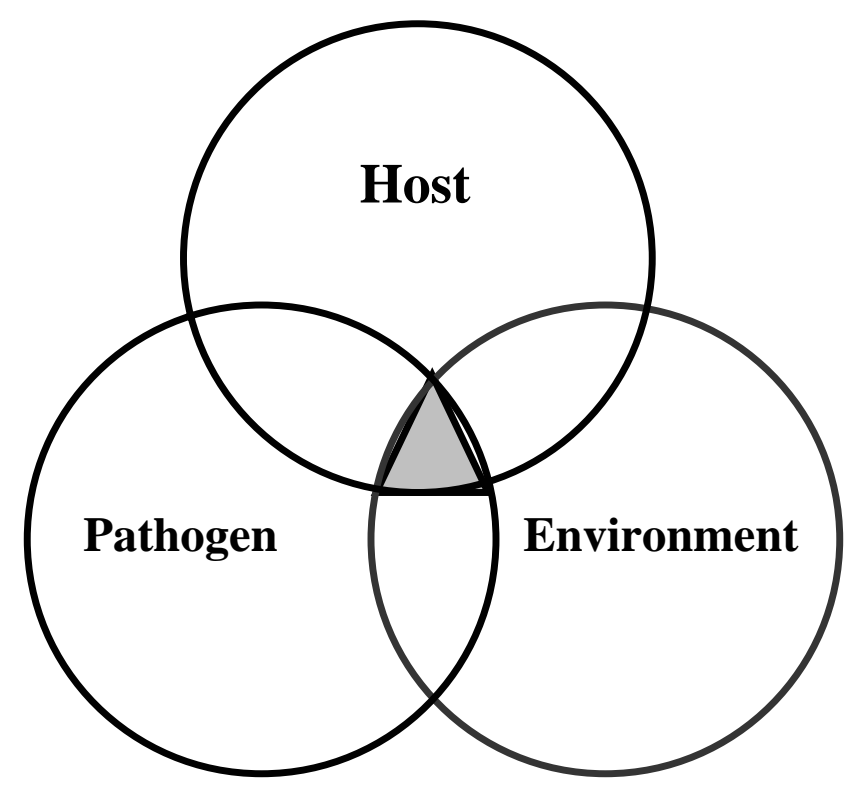

Figure 2.5 Diagram of Disease Outbreak Conditions

\subsubsection{Water Quality}

Water quality is arguably the most important issue related to successful aquaculture management. Management strategies that ensure the highest possible level of water quality include the following: do not exceed carrying capacity, frequent monitoring of levels of most limiting parameters, adjust these parameters if necessary and practical, proper aeration, proper sanitation (i.e. regular removal of debris, solid waste, mortalities, isolation of infected populations).

The water quality parameter that has the greatest impact on fish health and growth rate is water temperature. In Table 2.1 the water temperature ranges for survival and optimal growth of rainbow trout are given.

Table 2.1 Water Temperature Ranges.

\begin{tabular}{lccc}
\hline & Survival $^{*}$ & Optimum Range** & Optimum Growth* \\
\hline Temperature, ${ }^{\circ} \mathrm{C}$ & $0.6-25.6$ & $13-21$ & $10-15.6$ \\
Temperature, ${ }^{\circ} \mathrm{F}$ & $33-78$ & $55-70$ & $50-60$ \\
\hline \multicolumn{4}{c}{ * Piper et al..1982, ** Meade 1989 }
\end{tabular}


Several other parameters have been identified as important water quality factors for raising rainbow trout in aquaculture systems. These items and recommended levels from three literature sources are listed in Table 2.2.

Table 2.2 Water Quality Requirements.

\begin{tabular}{cccc}
\hline Parameter & Meade, 1989 & Standard* & Buttner et al.., 1993 \\
\hline Dissolved Oxygen & $5 \mathrm{mg} / \mathrm{L}$-saturation & & \\
$\mathrm{pH}$ & $6.5-8.0$ & $6.5-8.5 \mathrm{if} \mathrm{no} \mathrm{Al}$ & $6-9$ \\
Alkalinity (as $\left.\mathrm{CaCO}_{3}\right)$ & $10-400 \mathrm{mg} / \mathrm{L}$ & & $20-300 \mathrm{mg} / \mathrm{L}$ \\
Total Hardness $(\mathrm{ss}$ & $10-400 \mathrm{mg} / \mathrm{L}$ & $>50 \mathrm{mg} / \mathrm{L}$ \\
CaCO $_{3}$ ) & $<50 \mathrm{mg} / \mathrm{L}$ & $<850 \mathrm{mg} / \mathrm{L}$ & \\
Sulfate & $0.1 \mathrm{mg} / \mathrm{L}$ & \\
Total Iron & $<0.01 \mathrm{mg} / \mathrm{L}$ & $<0.087 \mathrm{mg} / \mathrm{L}$ & \\
Aluminum & $<0.01 \mathrm{mg} / \mathrm{L}$ & $<1.0 \mathrm{mg} / \mathrm{L}$ & \\
Manganese & $4-160 \mathrm{mg} / \mathrm{L}$ & & \\
Calcium & $<15 \mathrm{mg} / \mathrm{L}$ & $<28 \mathrm{mg} / \mathrm{L}$ & \\
Magnesium & &
\end{tabular}

* Standards that differ from Meade or which were more applicable to mine water were compiled by Heinen from various regulatory and literature standards.

As mentioned Section 2.3, treated mine waters often exceed the recommended levels of several of these parameters, yet trout have successfully been raised in them due to complexation and effects of high ionic strength. The ammonia levels can be adjusted to the determine unionized form, which is toxic to trout, using expressions given by Soderberg (1995). The unionized fraction, $\mathrm{f}$, is calculated by Equation 2.1.

$$
f=\frac{1}{10^{p K a-p H}+1}
$$

The unionized fraction is calculated by Equation 2.2.

$$
\text { Unionized Ammonia }=T A N \times f
$$

Equation 2.2 
The value, $\mathrm{pKa}$, is a function of temperature and is calculated by Equation 2.3, with $\mathrm{T}$ in ${ }^{\circ} \mathrm{C}$.

$$
p K_{a}=0.09018+\frac{2729.92}{T+273.15}
$$

$\mathrm{K}_{\mathrm{a}}$ is the equilibrium constant for ammonia and ammonium in solution.

After calculating the value of unionized ammonia, this concentration can be further corrected using the ionic strength, I. I is calculated by Equation 2.4.

$$
I=\Sigma \frac{\left(M_{i}\right)\left(z_{j}\right)^{2}}{2}
$$

$\mathrm{M}_{\mathrm{i}}$ is the molar concentration of the ion in solution and $\mathrm{z}_{\mathrm{j}}$ is the charge. This value is used in Equation 2.5 to calculate the salinity correction term, s.

$$
s=-\frac{A^{\prime} \sqrt{I}}{1+\sqrt{I}}
$$

Equation2.5

$A^{\prime}$ is a coefficient that is a function of temperature, and is presented in tabular form by Soderberg and Meade, 1991.

Now, the concentration of unionized ammonia can be calculated by putting the salinity correction term in Equation 5.1.1a to get Equation 2.6.

$$
f=\frac{1}{10^{p K a-p H-s}+1}
$$

Equation 2.6

The ionic strength was also used to calculate the activity coefficient, a, to correct the measured metal concentrations by Equation 2.7 (Snoeyink and Jenkins, 1980).

$$
\{i\}=a[i]
$$

Equation 2.7

where $\{\mathrm{i}\}$ is the active concentration of species $\mathrm{i}$ and [i] is the molar concentration of species $\mathrm{i}$. The activity coefficient, a, is calculated by Equation 2.8 .

$$
-\log a=\frac{|z| \sqrt{I}}{1+\sqrt{I}}
$$


Ionic strength can also be calculated using the field measured value of specific conductance using Equation 2.9.

$$
I=1.6 \times 10^{-5} \times \text { specific conducance }(\mu \mathrm{ohm} / \mathrm{cm})
$$

\section{Equation 2.9}

\subsubsection{Feeding}

Proper nutrition is a second line of defense against fish disease and can provide desired growth rates and feed conversions. These values are critical to the economic success of any operation. High quality feed should always be used. Appropriate feeding rates and frequency, as well as proper storage are crucial to optimize the value of the feed selected. Incomplete diets, over- or under-feeding can all increase the risk of health problems. Feed content, methods and quantities can also impact the amount of solid waste generated in the system.

\subsubsection{Stress Events}

Aside from extreme system upsets, there are a number of sources of stress to fish associated with typical aquaculture operations. These include transportation, fluctuating water temperature or quality, increased stocking density from growth, competition for food, system cleaning (i.e. solids removal), crowding and handling for inventory or growth monitoring. Minimizing the amount of stress to the fish in an aquaculture unit is crucial to reducing the health impacts of these events.

Susceptibility to disease has been linked to stress in fish reared in commercial aquaculture systems since the fish are unable to relocate when the source of stress is present. Stressors can be physical or chemical in nature. Physiological stress or injury can make fish in confined units weak and more likely to be affected by disease-causing pathogens present in most water sources. As a result, the spread of diseases are rapid in densely stocked units, and may result in high mortalities. 
Even though stress to fish in aquaculture units cannot be completely eliminated, there are a number of management strategies and methods that can reduce the frequency and severity of stress. Regular monitoring of water quality is one of the best, first steps to identifying and reducing sources of health-threatening stress conditions. In some cases, it may be possible to improve the overall quality of water, or at least predict the need for preventative treatments. Proper system cleaning and sanitation will provide the most likely opportunity for water quality improvement and disease prevention. Sufficient water supply is also often a controllable parameter to maintain good water quality.

As mentioned in the previous section, proper nutrition is also important for fish health. Underfed fish will not recover from stress events as well as properly fed fish will. Other stress related to feeding includes struggle during competition if insufficient quantities of food are provided, and increased oxygen demand on a concentrated system after feeding from the metabolic process.

Perhaps the largest and most reducible source of stress on fish is the transportation and handling during inventory sampling. Careless, extended, or too frequent handling of fish increases stress and possibility of injury. Anesthetization during handling can also reduce the level of stress experienced by the fish. Proper transportation and sampling methods will be discussed in the next chapter.

\subsubsection{Indicators of Health Issues}

The increased susceptibility of fish in commercial aquaculture systems, the diagnoses and treatment of diseases have been extensively documented in literature (Plumb, 1994; Durborow, 1996; Hinshaw, 2002). A number of physical signs of stress and compromised immune systems can be detected with regular and proper observation of fish physiology and behavior. Scaled 
fish, like rainbow trout, often provide visible physical indicators of a disease outbreak. Early detection and treatment are critical for prevention of large numbers of mortalities. A change in the natural defense systems in a large number of fish in a population are the first signs of increased stress and reduced health. Rainbow trout possess a mucus, or slime layer, as their first line of defense against infections. This layer acts as a physical barrier against disease causing organisms and minor environmental changes. Damage to this layer can be caused by injury during handling or aggressive behavior of other fish and can expose the fish to infection or chemical damage. Scales and skin also provide a physical protection barrier. Handling and overcrowding can damage these layers as well. Inflammation and ulceration are indicators of disease infestation. These external indicators are a natural response of the immune system to fight off foreign proteins and other substances.

Noticing changes in behavior is also necessary for identifying problems requiring immediate action. It is important to be familiar with "normal" behavior patterns of the type of fish one is working with. Deviations in swimming patterns, feeding, and response to various stimuli must be recognized to detect problems while they are still developing. Many diseases cause the fish to stop feeding all together. If a disease is not identified before this stage occurs, treatments like feed containing antibiotics will be ineffective.

Trout raised on farms are susceptible to two categories of disease, non-infectious and infectious. Non-infectious diseases are typically caused by environment factors while infectious diseases are a result of microbial pathogens like viruses, bacteria, fungi, protazoa or metazoa. Infectious diseases usually occur due to a decrease in resistance to these microbes caused by a non-infectious disease condition that the fish were unable to cope with. 
Non-infectious diseases include physiological diseases, psychological diseases, physical and chemical diseases. Some common examples are stress, environmental gill disease (EGD), fin-nipping, traumatic diseases, and metal toxicities. Infectious diseases include viral, bacterial, fungal, protozoan, and metazoan diseases.

Ultimately poor fish health will result in significant economic loss for the aquaculture operator. These losses will be realized in the most important indicators of production success: mortalities, feed conversion, and growth rate. Preventative management strategies and proper response to health issues are vital to the economic output of an aquaculture system.

\subsubsection{Feed Case Studies}

\subsubsection{High Appalachian, LLC.}

A feed trial was conducted by High Appalachian, LLC. from October 2, 2003 through December 22, 2003 comparing fish production in two rearing units supplied with different feeds. Tank 1 was fed the Zeigler Gold diet and Tank 2 was fed Freedom Feed VegiPRO®. The Zeigler Finfish floating and slow-sinking diets are manufactured by Zeigler Bros., Inc. They are used for trout, flounder, striped bass, haddock, arctic char, sea bass, and sea bream. Zeigler feed is marketed to have improved feed conversions, average fat content in flesh, low nitrogen effluent, and lower phosphorus effluent ( $<1.3 \%)$. The feed is purchased at $\$ 20.26$ per unit. Each unit is 44 lbs. yielding a cost of $\$ 0.447 / \mathrm{lb}$ of feed. The VegiPRO ${ }^{\circledR}$ diet by Freedom Feed is made of all vegetable protein sources and is slightly more expensive, $\$ 0.459 / \mathrm{lb}$. The content of both feeds provided by the manufacturers is presented in Table 2.3. 
Table 2.3 Dietary Content of Two Feed Sources.

\begin{tabular}{cccc}
\multicolumn{4}{c}{ Guaranteed Analysis } \\
\hline Component & Zeigler & VegiPRO & Level \\
\hline Protein, \% & 42 & 42 & Minimum \\
Fat, \% & 16 & 12 & Minimum \\
Fiber, \% & 4 & 4 & Maximum \\
Moisture, \% & 12 & -- & Maximum \\
Ash,\% & 8 & 6 & Maximum \\
Phosporus, \% & -- & 0.6 & Minimum \\
\hline
\end{tabular}

The experimental details and results are provided in the following tables, Table 2.4 and Table 2.5. Additional comments provided with this study included that Tank 2 adjusted to the new feed slowly and were only on it for two days before data collecting for the trial began. Further, recommendations for further study over a longer time period and for fish at 250 grams to harvest weight of 454 grams were given.

Table 2.4 Experimental Conditions for Feed Case Study.

\begin{tabular}{cc}
\hline Parameter & Both Tanks \\
\hline Feed Size & $3 / 16 "$ \\
Content & fat \\
Tank Size & Diameter $=23 \mathrm{ft}$ \\
& Depth $=5 \mathrm{ft}$ \\
Flow & $100 \mathrm{gpm}$ \\
Oxygen Added & $6 \mathrm{LPM}$ \\
No. Fish & 4200 \\
Initial Fish Size & $106 \mathrm{~g}$ \\
Initial Bio mass & $979 \mathrm{lb}$ \\
Qty. of Feed & $2 \%$ body weight \\
\hline
\end{tabular}


Table 2.5 Comparison of Experimental Parameters for Feed Case Study.

\begin{tabular}{ccc}
\hline Parameter & Tank 1 & Tank 2 \\
\hline Diet & Zeigler gold & Vegipro ${ }^{\circledR}$ \\
Mortalities & 23 & 30 \\
Total Feed & $1952 \mathrm{lb}$ & $1742 \mathrm{lb}$ \\
Final Fish Size & $276 \mathrm{~g}$ & $224 \mathrm{~g}$ \\
Final Bio mass & $2554 \mathrm{lb}$ & $2054 \mathrm{lb}$ \\
Weight Gain & $1575 \mathrm{lb}$ & $1075 \mathrm{lb}$ \\
Feed Conversion & 1.23 & 1.59 \\
\hline
\end{tabular}

These findings suggest that the vegetable based diet provided worse feed conversions, defined as weight gained per unit of feed. Even though the overall size of fish, total biomass, and weight gain in Tank 2 was less than Tank 1, this could possibly be attributed to the time period at the beginning of the study when the fish in Tank 2 were adjusting to the new diet. The data used in this investigation have not previously been published.

\subsubsection{Pennsylvania Fish and Boat Commission}

A rainbow trout diet study was conducted at the Benner Spring Fish Research Station in Center County, PA. The purpose was to compare the feed they had been using for many years to newer feeds that contained higher levels of protein and fat than their 38-11 feed. The feed conversions and growth rates reported on the new feeds were better, and the waste produced was lower; however, these feeds were also more expensive. Therefore the comparison was used to determine if the added cost of feed was justified by the improved results.

Three feeds were compared in the study. The original feed used at the site with a $38 \%$ protein and $11 \%$ fat content, and two high protein, high fat diets, one sinking and one floating. The parameters measured for comparison were feed conversion, solid waste produced, growth, survival, and cost. The details of the experimental design can be found in Bender et al. (1999). 
The mean values from proximate analyses of the three diets throughout the study are provided in Table 2.6 below.

Table 2.6 Results of Feed Analyses on Three Separate Diets.

\begin{tabular}{cccc}
\hline & $\begin{array}{c}\mathbf{3 8 - 1 1} \\
\mathbf{( \% )}\end{array}$ & $\begin{array}{c}\mathbf{4 2 - 1 8} \\
\text { Sinking } \\
\mathbf{( \% )}\end{array}$ & $\begin{array}{c}\mathbf{4 2 - 1 6} \\
\text { Floating } \\
\mathbf{( \% )}\end{array}$ \\
\hline Crude Protein & 37.3 & 43.3 & 41.0 \\
Fat & 11.4 & 19.1 & 15.9 \\
Moisture & 10.0 & 9.6 & 7.6 \\
Ash & 5.6 & 6.2 & 7.4 \\
Fiber & 3.8 & 1.2 & 1.3 \\
$\begin{array}{c}\text { Digestibility of } \\
\text { Protein }\end{array}$ & 91.0 & 93.6 & 90.6 \\
\hline
\end{tabular}

The overall results of the study are summarized in Table 2.7.

Table 2.7 Final Results of Study Comparing Three Diets.

\begin{tabular}{|c|c|c|c|}
\hline & $38-11(\%)$ & 42-18 Sinking (\%) & 42-16 Floating (\%) \\
\hline Total pounds fed & 15255 & 15269 & 13908 \\
\hline Total pounds weight gain & 9493 & 12961 & 11799 \\
\hline Feed conversion & 1.61 & 1.18 & 1.18 \\
\hline Cost (\$)/ pound feed & 0.18 & 0.37 & 0.32 \\
\hline $\begin{array}{c}\text { Cost }(\$) / \text { pound weight } \\
\text { gain }\end{array}$ & 0.29 & 0.44 & 0.38 \\
\hline $\begin{array}{c}\text { Total feed cost }(\$) \text { for } \\
\text { pounds fish weight } \\
\text { produced }\end{array}$ & 2745.90 & 5649.53 & 4450.56 \\
\hline $\begin{array}{l}\text { Total depth (ins.) of solids } \\
\text { produced }\end{array}$ & 182.0 & 140.9 & 127.0 \\
\hline $\begin{array}{c}\text { Pounds feed to produce an } \\
\text { inch of solids }\end{array}$ & 85.2 & 108.4 & 109.5 \\
\hline $\begin{array}{l}\text { Final mean fish length } \\
\text { (ins.) }\end{array}$ & 10.4 & 10.7 & 10.6 \\
\hline $\begin{array}{c}\text { Final mean fish weight } \\
\text { (lbs.) }\end{array}$ & 0.50 & 0.58 & 0.56 \\
\hline
\end{tabular}


The overall conclusions of the study based on the data above were that even though the higher protein and fat content of the two new diets yielded better feed conversions and weight gain, as expected, it did not make up for the higher cost of the feeds. The cost per pound of fish weight gain was still lower for the 38-11 diet the facility was already using. Mortalities were not affected by diet selection. There was a significant reduction in waste produced, which alone could justify a change in feed if effluent water quality limitations require it. Finally, there was no significant difference in these parameters between the two higher protein and fat diets. 


\section{CHAPTER 3. INVESTIGATE APPROACH}

\subsection{Site Description}

The research site was selected prior to the feasibility study reported on by Viadero and Tierney (2003). The site is approximately 10 miles from the West Virginia University Evansdale campus. The project is an ongoing effort located at a coal mine site owned by a large, international coal and energy producer. The water used for the study comes from the discharge point downstream of mine water treatment facility settling basin. The operation is conducted under the National Pollutant Discharge Elimination System (NPDES).

The pilot-scale, linear raceway system was designed and installed prior to the first year of full operation and was reported by Viadero et al. (2004). Figures 3.1 and 3.2 are detailed design diagrams of an individual raceway segment. A total of eight units were installed as four paired stages in series. During this years study, the middle screen shown in this original design was removed. In these figures, the water flow is from left to right. At the end of each unit is the quiescent zone with a standpipe used for solid waste removal. There is an approximately three foot drop from one unit to the next in series.

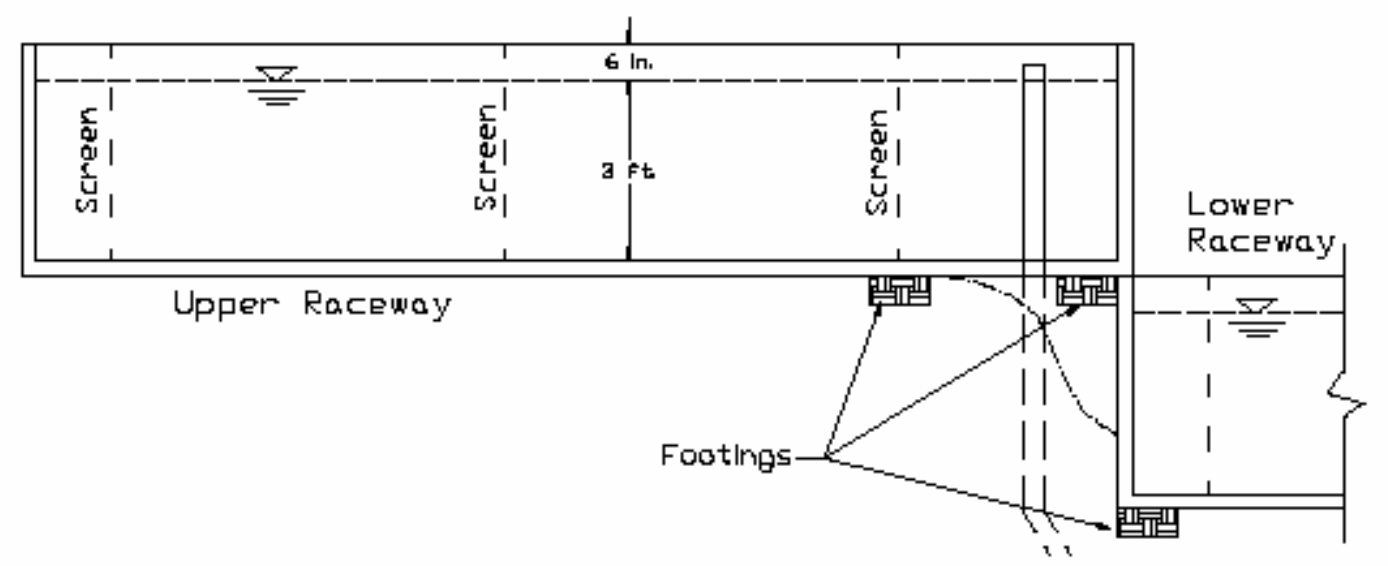

Figure 3.1 Profile View of Single Raceway Segment Design. 


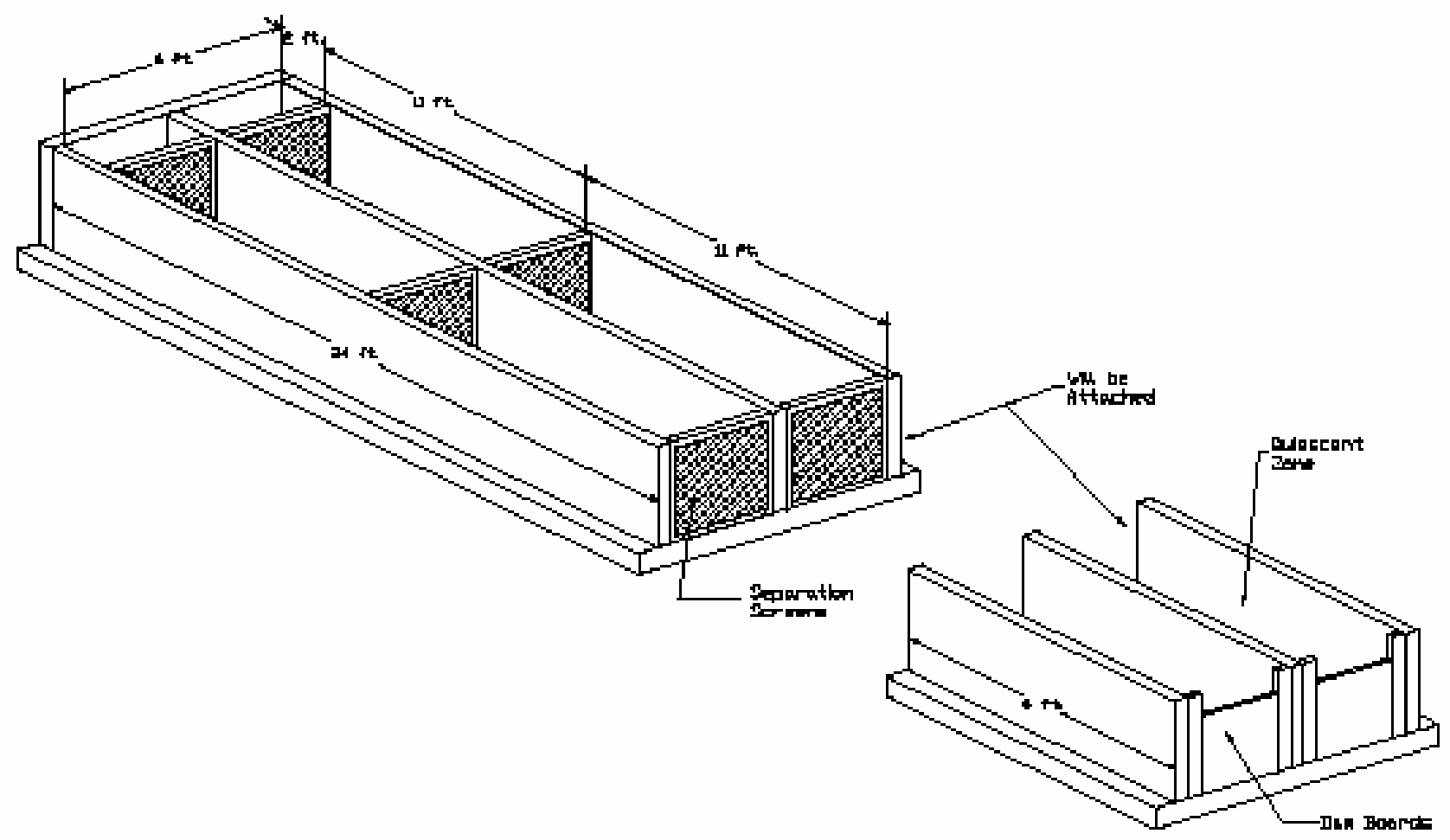

Figure 3.2 Single Raceway Segment Dimensions and Connection of Quiescent Zone.

Figure 3.3 is a plan view diagram of one stage of the raceway. Each stage contains a pair of units joined by a common wall operating in parallel. The water flow in each unit is equal. The dimensions are provided in this diagram as well. The two screens are used to keep the trout out of the water plunge zone and quiescent zone, respectively. Dam boards are placed at the end of each quiescent zone to control the water depth in each raceway segment. The top dam board is the outlet weir used to determine the flow rate of the system. The water flows over the outlet weirs to the next lower stage of units. Each unit is covered by a wire mesh screen. The screens were padlocked down to prevent debris from falling into the water, to keep wild animals from falling into the raceway, and as a security measure to prevent potential theft of the fish supply by local area inhabitants. 


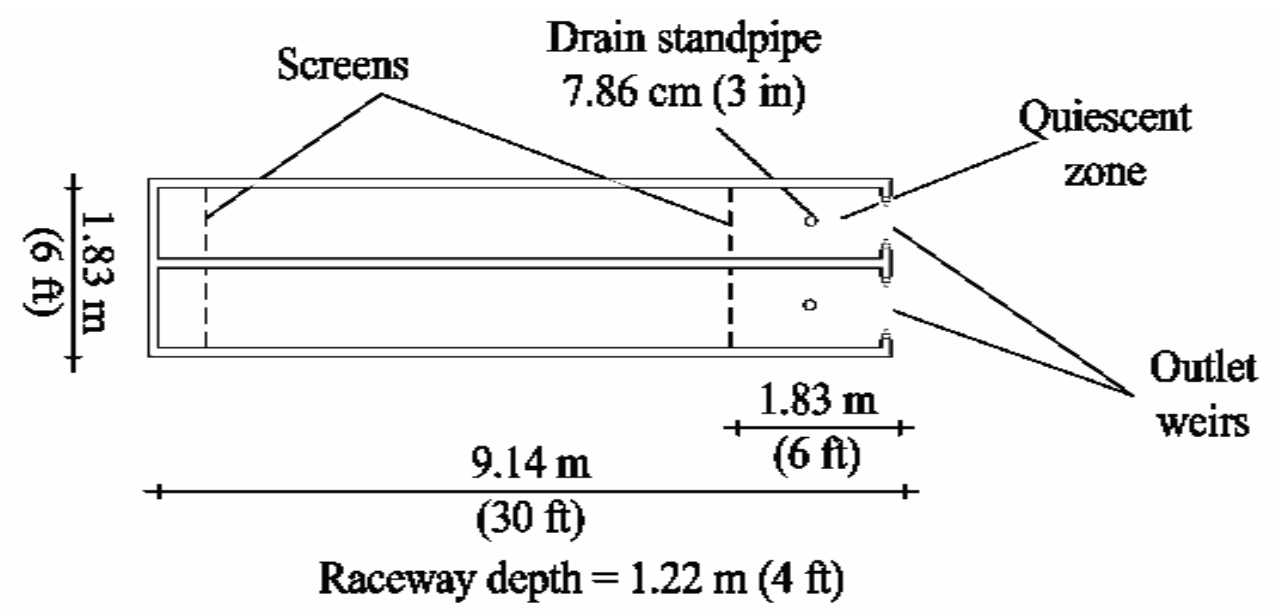

Figure 3.3 Plan View of One Stage of Raceway Segments.

Figure 3.4 below is a plan view of all four stages of the raceway system. The treated mine water enters the system from the left into the first section, the Head Box (HB), and is split into two equal streams flowing through Sides A and B in parallel. Side A is located on the left side when looking upstream of the water flow. As previously mentioned, there is a three foot drop from one stage to the next (i.e. from A1 to A2, or B1 to B2, etc.). The detention time for each stage is 15 minutes.

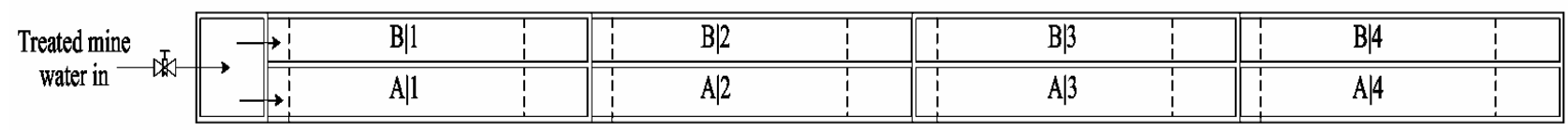

Figure 3.4 Plan View of All Four Stages of Raceway System.

The raceway unit is constructed of a novel honeycomb fiber reinforced polymer product. This material was selected in the original design because of the versatility of the system. The benefits include modular installation and the system would not be permanent since it could be more easily removed than a concrete system. A photograph of the site and a portion of the raceway is presented in Figure 3.5. 


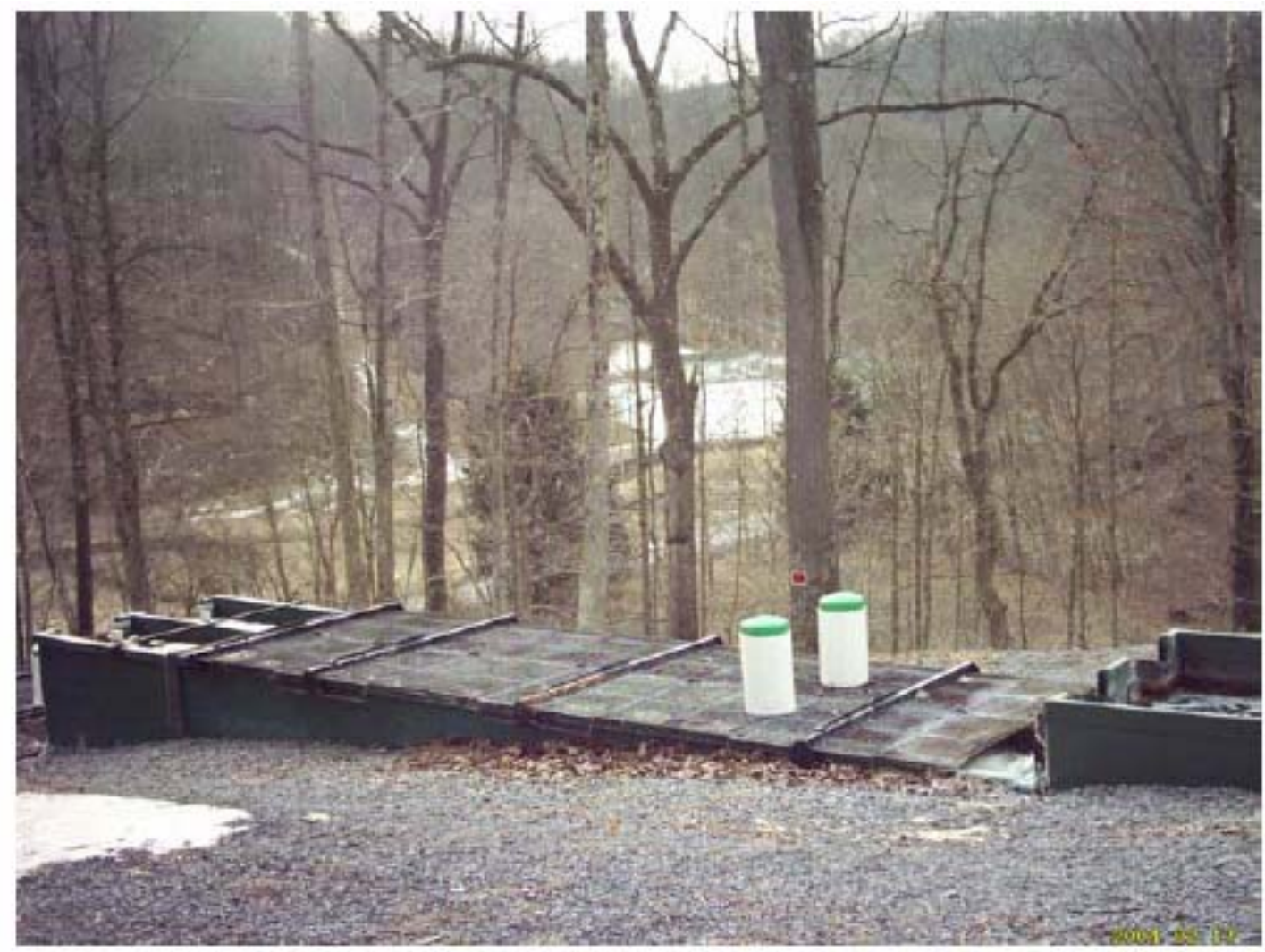

Figure 3.5 Photograph of the First Raceway Stage at the Research Site.

\subsection{Stocking of Fish Culture Units}

The focus of this study was on the first three stages of the raceway system described above. In these stages, approximately 1000 fish at an approximate weight of 90 grams each were stocked in each unit for a total of 6000 fish. The fish were transported in a temperature controlled, aerated tank truck to the site by High Appalachian, LLC on October 14, 2003. A sample of at least fifty fish from each tank was collected in a tub filled with water. A scale was tared with the tub of water; the sample was weighed and counted to determine the average weight of each fish. The remainder of the fish stocked were transferred from the tanks with a net and were only weighed. The average weight per fish calculated from the samples was used to determine the total number of fish in each unit. 


\subsection{Water Quality}

Water quality sampling was conducted every week. The two types of sampling were field monitoring and grab sampling. The locations of sampling for both of these were the same for both methods and can be seen in Figure 3.6. The locations are labeled as HB for the Head Box, and QZA\# and QZB\# the quiescent zone of each unit and stage \#.

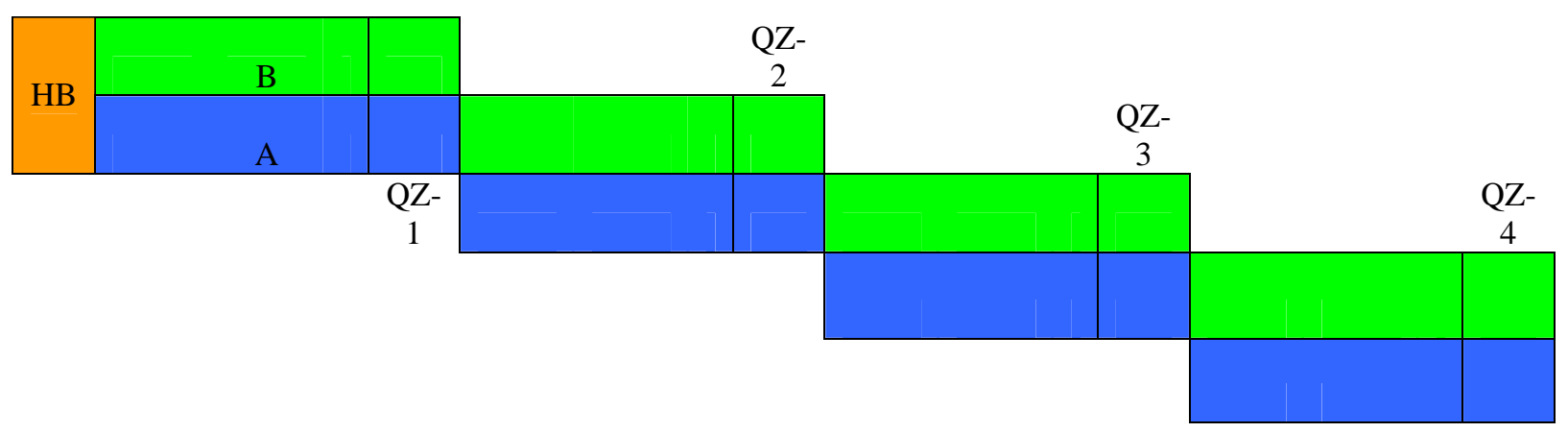

Figure 3.6 Water Sampling Sites for All Raceway Segments.

The water quality parameters measured through field monitoring were $\mathrm{pH}$, temperature, specific conductance, salinity, dissolved oxygen, turbidity and flow rate. All of these values were measured weekly. Grab samples were take for the determination of nutrients levels, metals, alkalinity, acidity, sulfates, $\mathrm{BOD}_{5}$ and total suspended solids (TSS). Only ammonia was analyzed weekly, all other analyses were conducted on monthly grab samples. The sampling regime described above is summarized in Table 3.1. 
Table 3.1 Summary of Field Monitoring and Grab Sampling Schedule.

\begin{tabular}{ccc}
\hline Parameter & Location & Frequency \\
\hline pH, temp, sp.cond., salinity & HB and all QZs & Weekly \\
DO (mg/L and \% sat) & HB and all QZs & Weekly \\
Turbidity & HB and all QZs & Weekly \\
$\mathrm{NH}_{3}$ & HB and all QZs & Weekly \\
Nutrients $\left(\mathrm{NO}_{3}, \mathrm{NO}_{2}, \mathrm{TP}\right)$ & HB and all QZs & Monthly \\
Metals (Fe, Al, Mn, Mg, Ca, Cu, Zn, & & \\
Ni) & HB, QZA4, QZB4 & Monthly \\
Alkalinity & HB, QZA4, QZB4 & Monthly \\
Acidity & HB, QZA4, QZB4 & Monthly \\
Sulfates & HB and all QZs & Monthly \\
BOD $_{5}$ & HB and all QZs & Monthly \\
TSS & HB and all QZs & Monthly \\
\hline
\end{tabular}

Grab samples were all collected in Nalgene bottles rinsed three times with the sample water, and with zero head space. Nutrient samples were preserved on site with concentrated nitric acid to a $\mathrm{pH}<2$. All samples were transported in a cooler to maintain a constant temperature until returning to the WVU-CEE laboratory, where the samples were stored at $4^{\circ} \mathrm{C}$. Metals and sulfate samples were filtered and preserved with acid immediately upon arrival at the laboratory. The instruments used for the field monitoring and the laboratory analysis of the grab samples are listed in Table 3.2.

Table 3.2 Summary of Instrumentation Used for Field Monitoring and Grab Sample Analysis.

\begin{tabular}{cccc}
\hline Parameter(s) Measured & Manufacturer & Model & Type of Instrument \\
\hline pH, Conductivity, Temperature & YSI & 63 & Field Meter \\
Dissolved Oxygen, \% Saturation, & YSI & 95 & Field Meter \\
Temp. & Hach & $2100 \mathrm{P}$ & Portable Turbidimeter \\
Turbidity & Marsh-McBirney & 2000 & Flow Meter \\
Volumetric Flow Rate & Onset Corp. & & Temperature Data Loggers \\
Water Temperature & Atomic Absorption \\
Dissolved/Total Metals & Perkin Elmer & 3100 & Spectrophotometer \\
Alkalinity, Acidity & Orion & $900 \mathrm{~A}$ & pH Meter \\
Sulfate Concentrations & Hach & DR/2010 & Spectrophotometer \\
\hline
\end{tabular}


Nurient concentrations in the grab samples were analyzed at the National Research Center for Coal and Energy (NRCCE), a West Virginia Department of Environmental Protection (WVDEP) certified laboratory using a Flow Injection Analyzer (FIA). Acidity, alkalinity, sulfate, TSS, and acid mine drainage metals were analyzed in house. Table 3.3 is a summary of the analytical methods used for these water quality measurements.

Table 3.3 Summary of Laboratory Methods Used for Grab Sample Analysis.

\begin{tabular}{cc}
\hline Assay & Method \\
\hline Alkalinity & Hach Method Number 8221 \\
Acidity & Hach Method Number 8219 \\
Sulfates & Hach Method Number 8051 with Accu Vac \\
Total Suspended Solids & EPA Method 160.2 \\
Iron & EPA Method 236.1 \\
Aluminum & EPA Method 202.1 \\
Manganese & EPA Method 243.1 \\
Calcium & EPA Method 215.1 \\
Magnesium & EPA Method 242.1
\end{tabular}

\subsection{Feeding}

Two diet treatments were selected for comparison in this study. The first diet was Ziegler Gold, Finfish floating and slow-sinking feed, manufactured by Zeigler Bros., Inc. The second feed was Freedom Feed VegiPRO ${ }^{\circledR}$, a feed with only vegetable based protein. Both feeds are high fat, high protein diets, 42-16 and 42-12, respectively. Raceway A was fed the Ziegler diet and Raceway B was fed VegiPRO®. During the cold months of the winter season, at the front end of the study, both sides of the raceway were fed every other day. They were fed by hand to satiation and 2-3 units of feed were placed in the demand feeders pictured in Figure 3.4.1. Feeding response and quantity were recorded, and the quantity of food placed in the feeders was adjusted accordingly. The fish were not fed aggressively during times when the water temperature was below the optimal range. 
The feeding strategy was more aggressive in the spring when water temperatures rose back into the optimum growth range. Feeding frequency increased to daily. The fish were still fed by hand to get started and as many as 10-12 units of feed were placed in each feeder, depending on the feeding response and quantity remaining from the previous feeding.

Samples of feed were collected periodically throughout the study to determine the weight of each unit. This value was used to calculate the total quantity of feed given to each raceway segment each day. The total feed put into the system was used to determine the feed conversion ratio. The demand feeder was selected as the most effective feeding method for the system. Its function can be seen in Figure 3.7. One demand feeder was installed in each raceway segment.

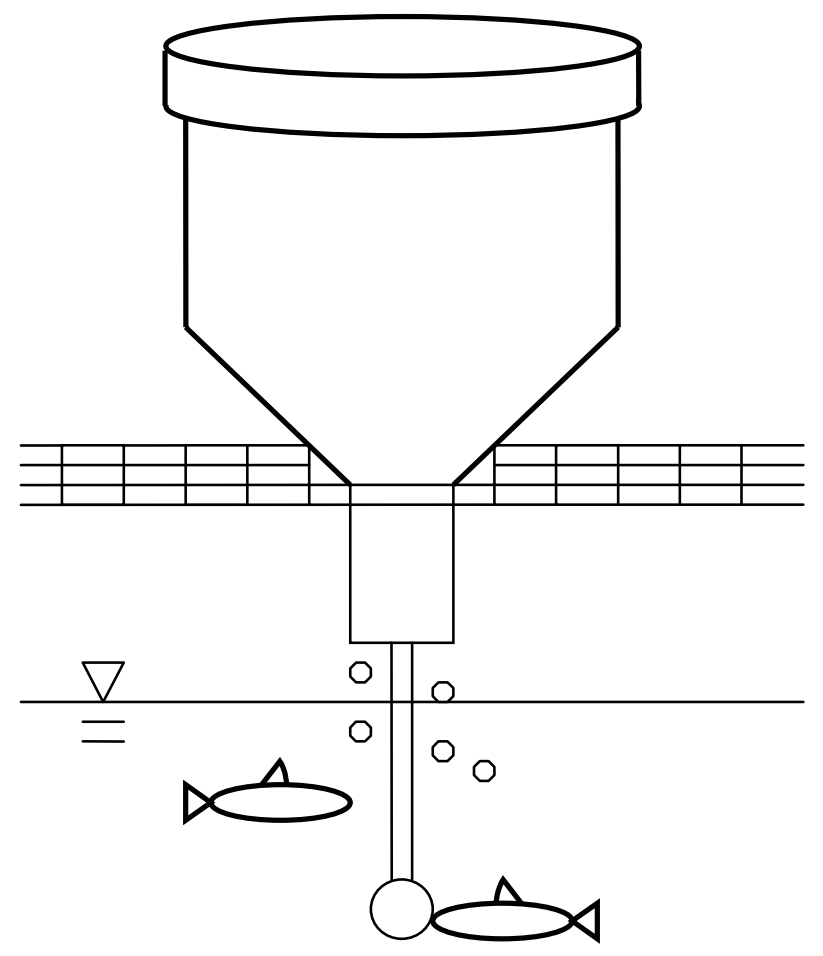

Figure 3.7 Diagram of Demand Feeder Installed in Each Raceway Segment. 
Presented in Figure 3.8 is a photograph of the demand feeders installed on each raceway segment at the site. The feeders are held in place by 12 inch white PVC pipe segments, which are anchored to the screen over the first section of each raceway segment containing the fish.

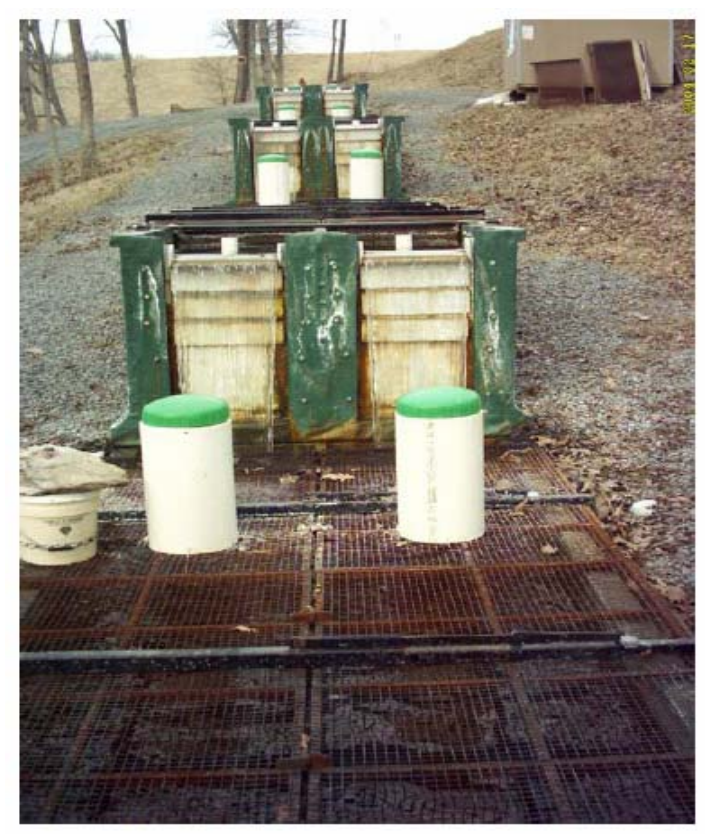

Figure 3.8 Photograph of Demand Feeders Installed on Each Raceway Segment.

\subsection{Fish Population}

The fish population was sampled once each month in all raceway segments for inventory purposes and to monitor growth in weight and length. A minimum of fifty fish were sampled from each segment. The sampling method used was a "grab" sample with crowding. All the fish in each segment were crowded with a metal screen from the beginning of the segment toward the quiescent zone. The fish were moved to approximately one third of the length of the segment so that random grab samples could be effectively obtained.

One half of each sample was managed at a time to minimize the stress imposed on the fish. Approximately 25 fish were collected with a net and placed in a tub of water of known weight. The total weight of the sample was recorded using a scale. An anesthetic, Tricaine- $\mathrm{S}^{\mathrm{TM}}$, was administered prior to handling for length measurement of each fish in the sample at a dose 
of $50 \mathrm{mg} / \mathrm{L}$. All fish sampled were counted, measured, and placed in the non-crowded section of the raceway segment to prevent the possibility of being sampled more than once in a period. The average weight per fish of the sample was used to determine growth rate and overall biomass of each unit. After sampling in each unit, the screen used for crowding was removed immediately to allow the population to spread back out.

\subsection{Aqua-sludge}

Aqua-sludge is defined as all the solid waste that collects in the quiescent zone and consists mostly of feces, uneaten feed, and shed skin. Regular removal of these wastes is important for maintaining a clean system and reducing the growth of bacteria and nutrient levels. These solids were sampled three times during the course of this project.

The sampling period was 24 hours after the previous cleaning to determine the quantity of solid waste generated in each unit per day. The solids were collected by siphoning through a hose attached to a wooden rod. All of the solids in the quiescent zone were collected in large tubs of known volume. The total volume was recorded. The sludge was stirred by hand constantly while samples were collected in Nalgene bottles with zero head space. The nutrient samples were preserved by acidification; all samples were transported to the laboratory in a cooler and stored at $4^{\circ} \mathrm{C}$ for analysis. The samples were analyzed for total suspended solids, total solids, nutrients, metals and $\mathrm{BOD}_{5}$. The methods and instrumentation provided in the water quality section of this chapter were also used for these analyses.

\subsection{Quality Assurance and Quality Control}

\subsubsection{Grab Sample Analysis}

During all water quality sample collection times, a triplicate sample was collected to be analyzed. These samples were all taken from the quiescent zone of raceway segment B4 at the 
same time as all other samples. These samples were tested separately for all water quality analysis conducted both in-house and at external laboratories. Other quality checks included lab replicates, spike samples, calibration blanks and calibration standards. Lab replicates were conducted on a single sample split into two sub-samples, tested separately, and the results were compared for accuracy. Spike samples were samples with an addition of known volume and concentration of indicator and the theoretical results were calculated and compared to the test results. Calibration blanks utilized a sample of de-ionized water measured for concentration before the grab samples. De-ionized water was also used to "zero" instruments. Finally, calibration standards were used to calibrate laboratory instruments used in analysis.

\subsubsection{Field Monitoring}

YSI field meters were calibrated at the beginning of each sampling trip. All probes were regularly cleaned and maintained according to the manufacturer's guidelines. The DO membrane was replaced as needed, and turbidity standards were used to calibrate the turbidimeter in the laboratory before going to the site. The ionic strength of the water was calculated using an average value measured with the field meter to ensure all significant ions were accounted for.

\subsubsection{Fish Sampling}

During fish population sampling, methods were used to ensure randomization of the collected samples. These included crowding the fish, netting the fish at half of the water depth, and sampling at least five per cent of the estimated population. Additionally, sampled fish were returned to the section of the raceway separated from the remaining crowded fish to prevent the same fish from being sampled more than once. 


\subsection{Statistical Analysis}

The paired $t$-test was used to evaluate field monitoring data, data from laboratory analysis of grab samples, and calculated growth rates and feed conversions for the two feed treatments. Values obtained from this test for these data sets were used to determine whether or not the differences between them were statistically significant. The purpose was to identify if the sampling event had a significant effect on the system and if differences in the data sets could be attributed to random variability. The value of the $t$-test statistic is calculated using Equation 3.1.

$$
t=\frac{\text { mean difference of the data sets }}{s \tan \text { dard error of the mean difference }}
$$

Equation 3.1

For absolute values of $t$ close to zero, one can assume no statistical significance between the data sets. A statistically significant difference was determined for absolute values of $t$ that were greater than two.

The paired $t$-test is a parametric statistical method used for normally distributed data sets that have equal variance. A 95\% level of confidence, a value of $\alpha=0.05$, and $P=0.05$ were used in the calculations. Confidence intervals were also calculated. If the confidence interval contained zero, there was no statistical significance (SPSS 1997). The confidence level is the level of certainty one has in assuming that the data were within the confidence interval. This means that one could be $95 \%$ confident that the difference of the population means fell within the confidence interval (Hogg and Ledolter 1992).

Alpha was the acceptable probability that a conclusion of statistical significance was incorrect. Therefore, a 5\% chance of error was acceptable. The $P$ value was the probability of wrongly concluding that a significant effect was observed. A value of $P<0.05$ indicated no statistical difference. 


\section{CHAPTER 4. RESULTS}

\subsection{Water Quality}

\subsubsection{Field Monitoring}

The results for field monitoring data collected for $\mathrm{pH}$, salinity, specific conductance, and dissolved oxygen are presented in Table 4.1. Both the average values and range are given to show the degree of variance in each variable. Only measurements from the head-box and the final quiescent zones of the two sides are provided. This is due to the fact that there was no significant difference in these variables from one stage to the next, with the exception of dissolved oxygen, which will be reported later this chapter. This is supported by trend analysis performed by Viadero et al., 2004. A complete table of the data collected for these values are presented in Tables B.1 - B.5.

Table 4.1 Field Monitoring Data Summary of Insignificantly Varying Parameters.

\begin{tabular}{cccccc}
\hline $\begin{array}{c}\text { Sample } \\
\text { Location }\end{array}$ & $\begin{array}{c}\mathbf{p H} \\
\text { average } \\
\text { [range] }\end{array}$ & $\begin{array}{c}\text { Salinity } \\
\text { (ppt) } \\
\text { average } \\
\text { [range] }\end{array}$ & $\begin{array}{c}\text { Sp.Cond (mS/cm) } \\
\text { average } \\
\text { [range] }\end{array}$ & $\begin{array}{c}\text { DO (mg/L) } \\
\text { average } \\
\text { [range] }\end{array}$ & $\begin{array}{c}\text { Flow (gpm) } \\
\text { average } \\
\text { [range] }\end{array}$ \\
\hline Head Box & 7.98 & 3.4 & 6.21 & 10.38 & -- \\
& {$[7.63-8.30]$} & {$[3.1-3.7]$} & {$[5.7-6.72]$} & {$[8.28-12.80]$} & -- \\
QZ-A4 & 7.91 & 3.4 & 6.23 & & \\
& {$[7.43-8.40]$} & {$[3.1-3.7]$} & {$[5.70-6.71]$} & {$[5.99-11.76]$} & {$[172.5-637.9]$} \\
QZ-B4 & 7.93 & 3.4 & 6.23 & & \\
& {$[7.51-8.40]$} & {$[3.1-3.7]$} & {$[5.70-6.71]$} & {$[5.91-11.61]$} & {$[201.4-637.9]$} \\
\hline
\end{tabular}


The temperature data collected in the Head Box for the entire season is plotted in Figure 4.1. The survival and optimum growth temperature lines are also included on the plot. At no time during the season was the water temperature out of the range of survival for rainbow trout. However, the fish were only in the optimum growth range for about a total of 12 weeks before December and after March. The temperature did not change significantly from one stage to the next. Complete temperature data are presented in Table B.6.

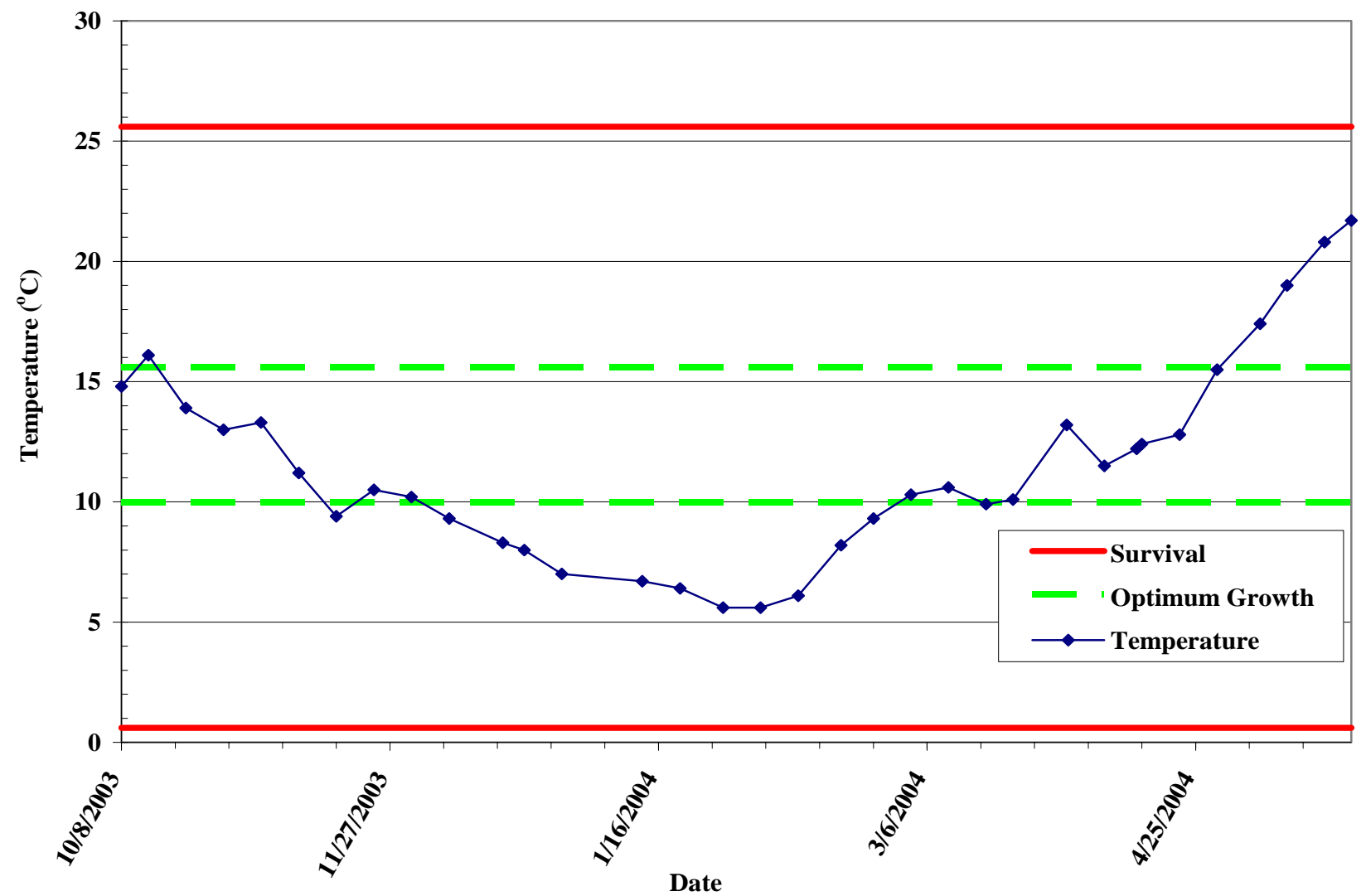

Figure 4.1 Field Monitoring Temperature Measurements.

The dissolved oxygen is one variable that did vary significantly from one segment of the raceway to the next, as previously mentioned. Presented in Figure 4.2 is a plot of data collected on October 27, 2003. Each maximum corresponds to the DO at the beginning of each stage; each minimum corresponds to the quiescent zone at the end of each stage. As the water passes 
through each stage of the system, the DO decreases due to fish respiration. With an approximate drop of $4 \mathrm{ft}$ from each stage to the next, sufficient re-aeration is accomplished from the flow over the weir into the turbulent plunge area below.

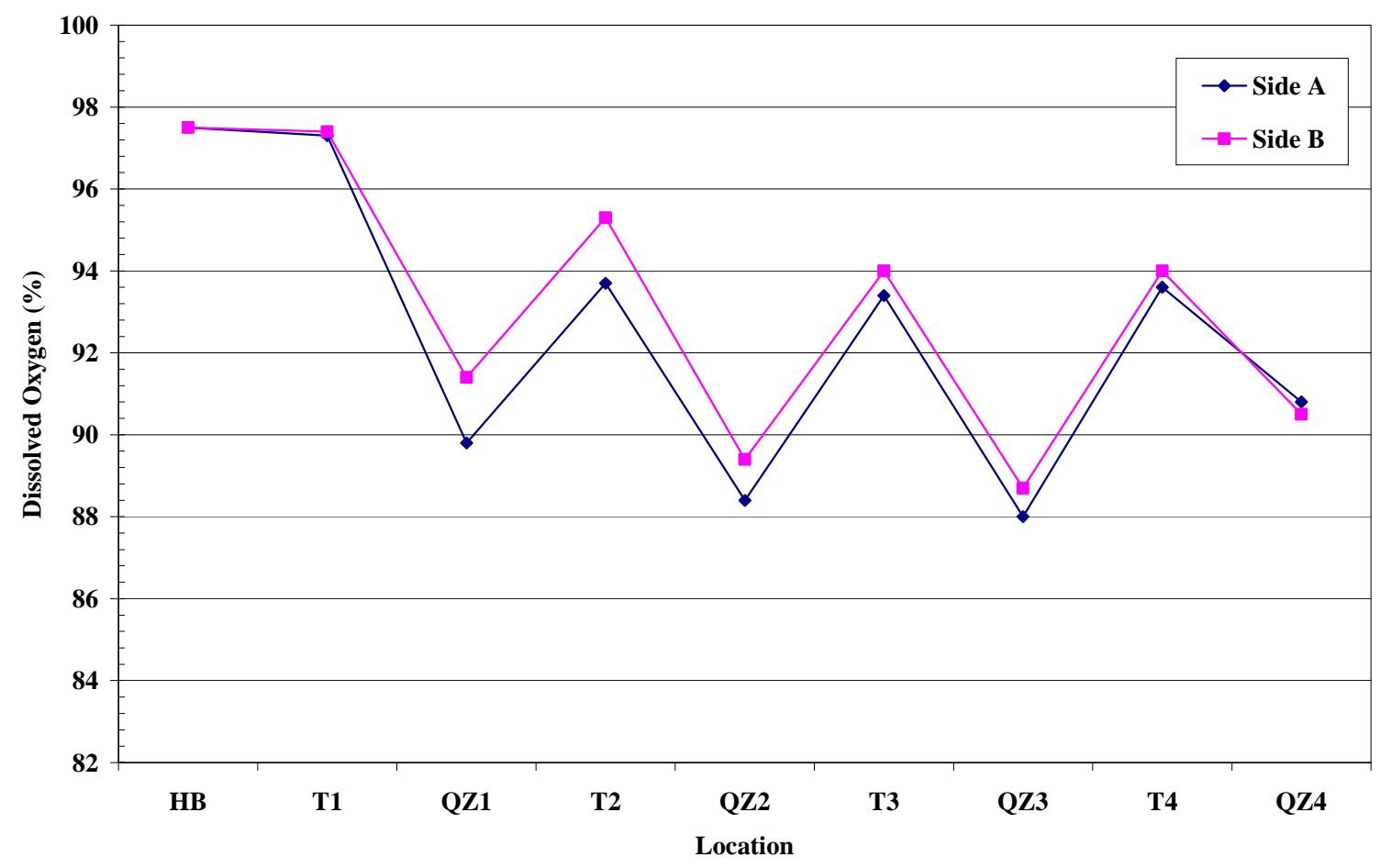

Figure 4.2 Field Monitoring Dissolved Oxygen Measurements.

The trend in the data presented in Figure 4.2 does not vary throughout the season, although there were differences in magnitude throughout the year. Dissolved oxygen is affected by temperature, fish size and density, and feed applied. These effects are demonstrated in Figure 4.3, which is a plot of the data gathered in the final quiescent zone A4 throughout the season. As the temperature and fish size increase toward the end of the season, the DO level decreases. These values are all well above the recommended level of $5 \mathrm{mg} / \mathrm{L}$. The variations seen in the figure can be explained by several additional factors that affect the DO during the course of a 
day. These include the fish metabolic process after feeding, wind, sunlight, consumption by algae and solids removal. Complete dissolved oxygen data are presented in Table B.4.

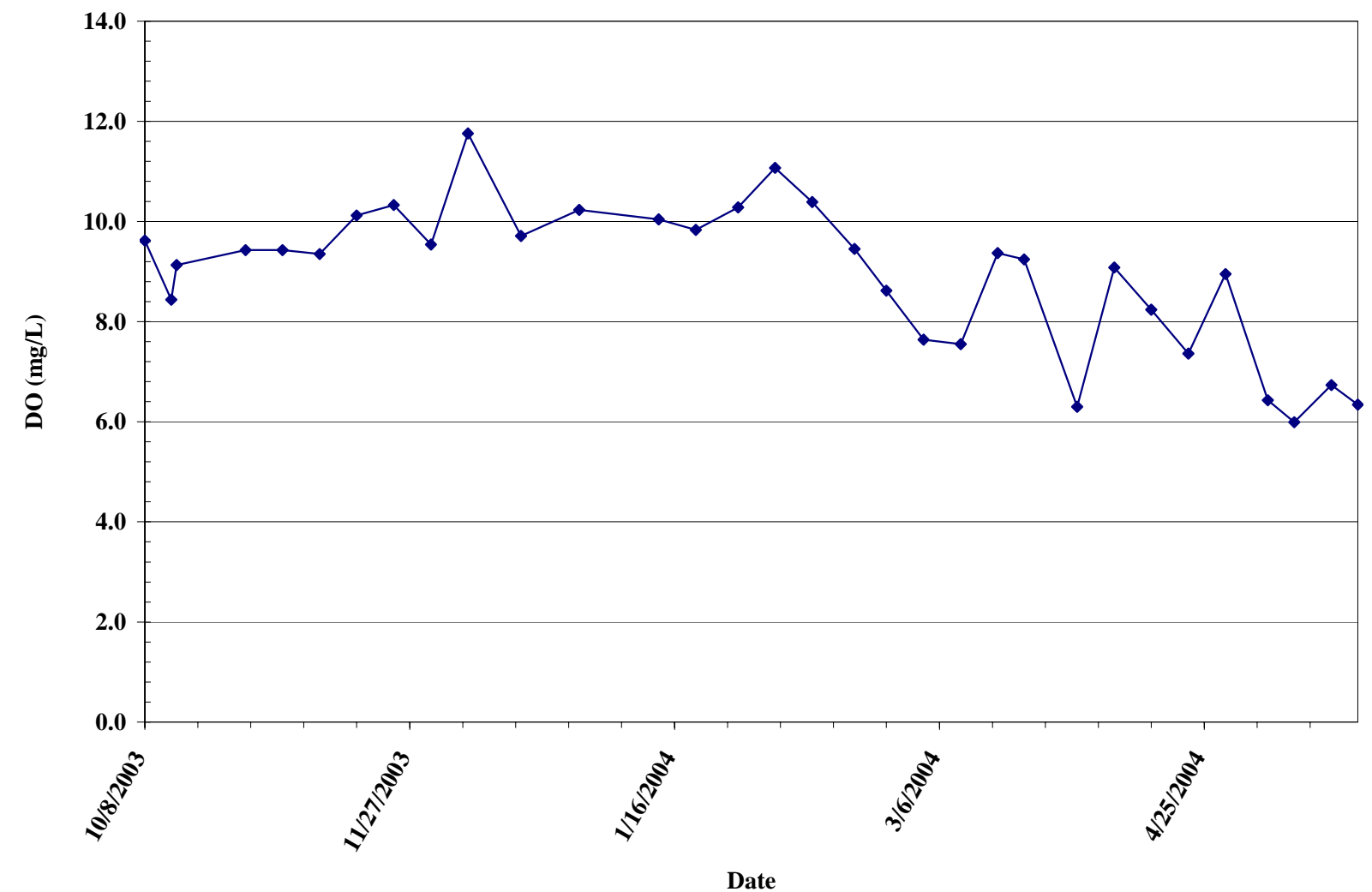

Figure 4.3 Effects of Temperature and Fish Growth on Dissolved Oxygen.

Turbidity is the final measurement taken with a field instrument. Figure 4.4 is a plot of the turbidity data collected during the season. For the majority of the time, the measurements were below 5 NTU. However, on two different occasions, the turbidity values spiked to 21.7 NTU and 46.7 NTU in the Head Box on March 10, 2004 and April 14, 2004, respectively. These two events and their impacts will be addressed in detail later in this chapter and in the discussion chapter. Complete turbidity data are presented in Table B.7. 


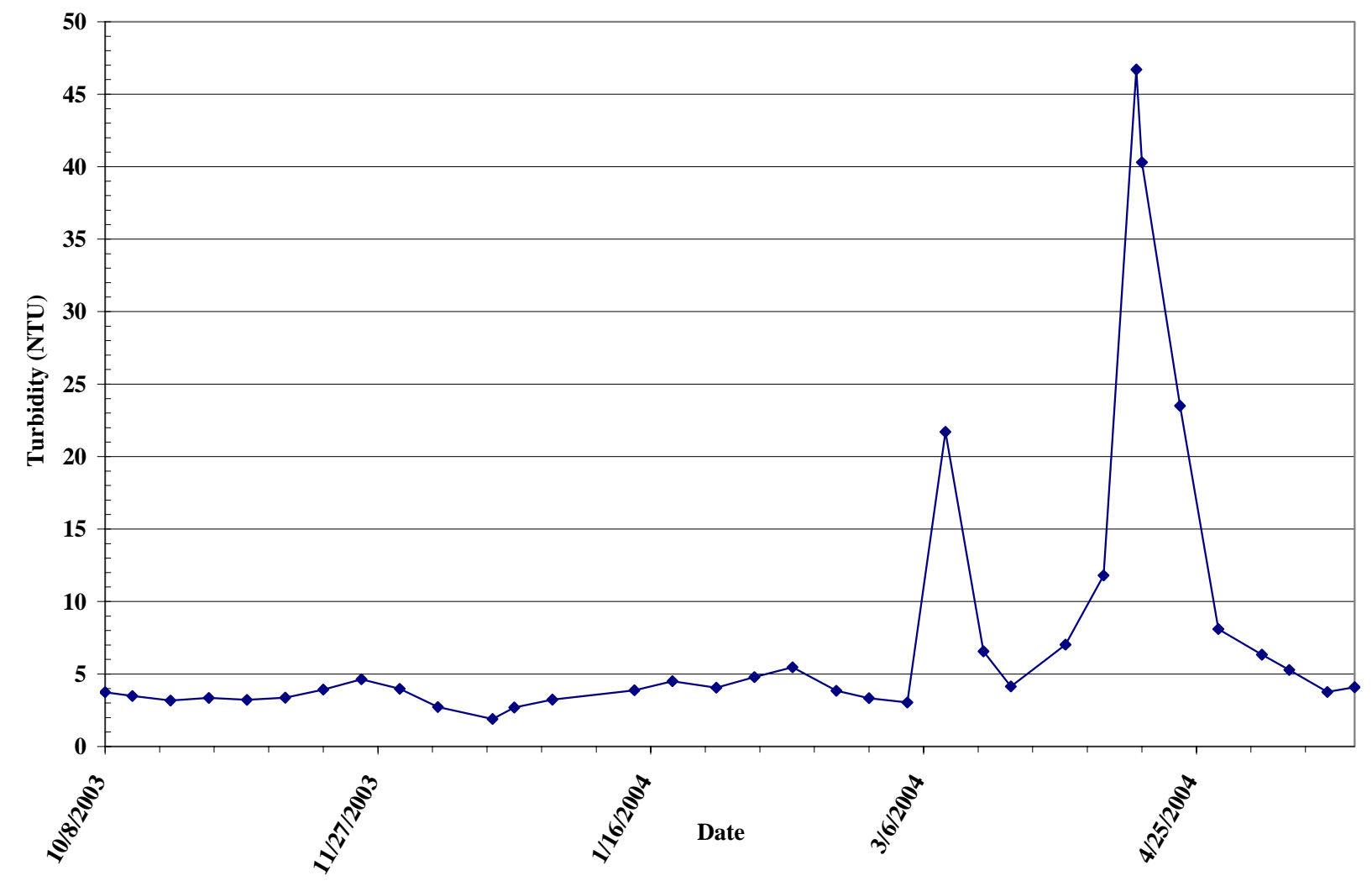

Figure 4.4 Field Monitoring Turbidity Measurements.

Additional turbidity data was collected throughout the season with hourly readings from a Sondes meter placed in the Head Box and the final quiescent zones of both sides of the raceway. The data from the Head Box is presented as daily averages in Figure 4.5. This figure presents a clearer picture of the extent and duration of the turbidity disturbances. The second disturbance event was much more severe and lasted longer than the field meter readings indicate. 


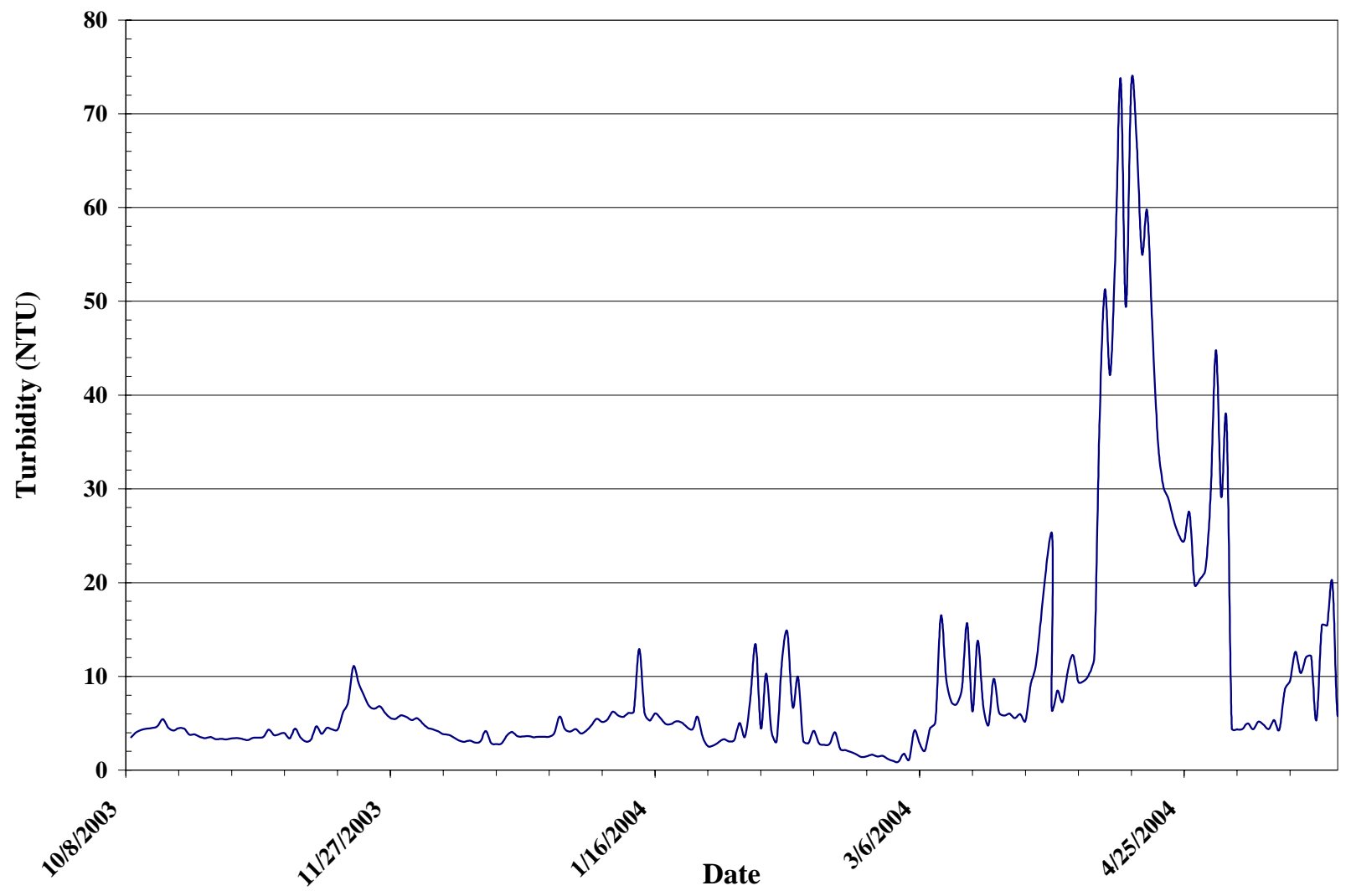

Figure 4.5 Sondes Meter Turbidity Measuremetns

\subsubsection{Grab Samples}

The results of the grab sample analysis conducted by WVU-CEE researchers for acidity, alkalinity, sulfates, TSS and $\mathrm{BOD}_{5}$ are summarized in Table 4.2. The sulfate values are molar concentrations, not active. Complete data are presented in Table B.8.

Table 4.2 Grab Sample Data Summary.

\begin{tabular}{cccccc}
\hline $\begin{array}{c}\text { Sample } \\
\text { Location }\end{array}$ & $\begin{array}{c}\text { Alkalinity (eq/L) } \\
\text { average } \\
\text { [range] }\end{array}$ & $\begin{array}{c}\text { Acidity (eq/L) } \\
\text { average } \\
\text { [range] }\end{array}$ & $\begin{array}{c}\text { Sulfates (mg/L) } \\
\text { average } \\
\text { [range] }\end{array}$ & $\begin{array}{c}\text { TSS (mg/L) } \\
\text { average } \\
\text { [range] }\end{array}$ & $\begin{array}{c}\text { BOD } \\
\text { average } \\
\text { [range] }\end{array}$ \\
\hline Head Box & 332.6 & 11.6 & 3092 & 4.25 & 0.96 \\
& {$[127-420]$} & {$[1.0-18.0]$} & {$[2350-3660]$} & {$[2.0-7.0]$} & {$[0.64-1.42]$} \\
QZ-A4 & 336.8 & 12.6 & 3169 & 5.88 & 3.10 \\
& {$[140-419]$} & {$[6.0-18.0]$} & {$[2990-3300]$} & {$[1.5-11.0]$} & {$[0.78-6.36]$} \\
QZ-B4 & 334.9 & 11.75 & 3085.7 & & 1.85 \\
& {$[140-415]$} & {$[5.0-17.0]$} & {$[2440-3830]$} & {$[3.48-8.0]$} & {$[1.03-3.38]$} \\
\hline
\end{tabular}


The nutrient analysis on the grab samples was performed at the NRCCE laboratory. The results of the analysis are summarized for the season in Table 4.3. These values are all analytical concentrations and have not been corrected for ionic strength. The ammonia levels are reported as total ammonia nitrogen (TAN), and were above the recommended level throughout the study. However, when these values were adjusted with the $\mathrm{pH}$, temperature and ionic strength of the water, the levels of unionized ammonia, which is the toxic form for trout, were within the acceptable range. All other nutrient species were also within recommended limits. Complete data are presented in Tables B.9 and B.10.

Table 4.3 Grab Sample Nutrient Data Summary.

\begin{tabular}{ccccc}
\hline $\begin{array}{c}\text { Sample } \\
\text { Location }\end{array}$ & $\begin{array}{c}\mathrm{NO}_{2}(\mathbf{m g} / \mathbf{L}) \\
\text { average } \\
\text { [range] }\end{array}$ & $\begin{array}{c}\mathrm{NO}_{3}(\mathbf{m g} / \mathbf{L}) \\
\text { average } \\
\text { [range] }\end{array}$ & $\begin{array}{c}\text { TAN (mg/L) } \\
\text { average } \\
\text { [range] }\end{array}$ & $\begin{array}{c}\text { TP (mg/L) } \\
\text { average } \\
\text { [range] }\end{array}$ \\
\hline Head Box & $\begin{array}{c}0.01 \\
{[<0.01\}}\end{array}$ & $\begin{array}{c}0.255 \\
{[0.14-0.68]}\end{array}$ & $\begin{array}{c}2.47 \\
{[2.23-2.88]}\end{array}$ & $\begin{array}{c}0.257 \\
{[<0.01-1.06]}\end{array}$ \\
QZ-A4 & 0.03 & 0.303 & 2.56 & 0.115 \\
& {$[<0.01-0.03]$} & {$[0.18-0.76]$} & {$[2.20-2.86]$} & {$[0.042-0.186]$} \\
QZ-B4 & $<0.01$ & 0.26 & 2.48 & 0.096 \\
& {$[<0.01\}$} & {$[0.16-0.68]$} & {$[2.34-2.76]$} & {$[0.02-0.16]$} \\
\hline
\end{tabular}

Grab samples taken monthly were also analyzed for dissolved metals content in the WVU-CEE laboratory. The values obtained for each metal relevant to rainbow trout raised in mine water are summarized for the season in Table 4.4. The values are analytical concentrations not adjusted for ionic strength. Complete data for these measurements are provided in Table B.11. Some species have significant variation in the ranges provided. This is related to the turbidity spikes during the disturbance events on March 13, 2004 and April 14, 2004. Complete water quality data during these events will be provided in a separate section later in this chapter. 
Table 4.4 Grab Sample Metals Data Summary.

\begin{tabular}{|c|c|c|c|c|c|c|c|c|}
\hline $\begin{array}{c}\text { Sample } \\
\text { Location }\end{array}$ & $\begin{array}{c}\text { Fe } \\
(\mathrm{mg} / \mathrm{L}) \\
\text { average } \\
\text { [range] }\end{array}$ & $\begin{array}{c}\text { Al } \\
(\mathrm{mg} / \mathrm{L}) \\
\text { average } \\
\text { [range] }\end{array}$ & $\begin{array}{c}\text { Mn } \\
(\mathrm{mg} / \mathrm{L}) \\
\text { average } \\
\text { [range] }\end{array}$ & $\begin{array}{c}\text { Ca } \\
(\mathrm{mg} / \mathrm{L}) \\
\text { average } \\
\text { [range] }\end{array}$ & $\begin{array}{c}\text { Mg } \\
\text { (mg/L) } \\
\text { average } \\
\text { [range] }\end{array}$ & $\begin{array}{c}\mathrm{Ni}(\mathrm{mg} / \mathrm{L}) \\
\text { average } \\
\text { [range] }\end{array}$ & $\begin{array}{c}\text { Zn (mg/L) } \\
\text { average } \\
\text { [range] }\end{array}$ & $\begin{array}{c}\text { Cu (mg/L) } \\
\text { average } \\
\text { [range] }\end{array}$ \\
\hline$M D L$ & 0.01 & 0.05 & 0.1 & 0.1 & 0.1 & 0.01 & 0.01 & 0.01 \\
\hline Head & 0.128 & $<0.05$ & 0.36 & 363 & 98 & 0.037 & 0.03 & 0.018 \\
\hline Box & {$[0.04-0.37]$} & {$[<0.05]$} & {$[0.27-0.48]$} & [355-370] & [83-108] & {$[0.01-0.07]$} & {$[<0.01-0.04]$} & {$[<0.01-0.03]$} \\
\hline QZ-A4 & $\begin{array}{c}0.118 \\
{[0.04-0.35]}\end{array}$ & $\begin{array}{l}<0.05 \\
{[<0.05]}\end{array}$ & $\begin{array}{c}0.37 \\
{[0.26-0.48]}\end{array}$ & $\begin{array}{c}356 \\
{[350-363]}\end{array}$ & $\begin{array}{c}95 \\
{[84-105]}\end{array}$ & $\begin{array}{c}0.032 \\
{[0.01-0.06]}\end{array}$ & $\begin{array}{c}0.04 \\
{[<0.01-0.07]}\end{array}$ & $\begin{array}{c}0.018 \\
{[<0.01-0.03]}\end{array}$ \\
\hline QZ-B4 & $\begin{array}{c}0.122 \\
{[0.04-0.37]} \\
\end{array}$ & $\begin{array}{l}<0.05 \\
{[<0.05]}\end{array}$ & $\begin{array}{c}0.36 \\
{[0.27-0.47]} \\
\end{array}$ & $\begin{array}{c}357 \\
{[349-368]} \\
\end{array}$ & $\begin{array}{c}94 \\
{[83-103]}\end{array}$ & $\begin{array}{c}0.038 \\
{[0.01-0.09]}\end{array}$ & $\begin{array}{c}0.03 \\
{[<0.01-0.04]}\end{array}$ & $\begin{array}{c}0.015 \\
{[<0.01-0.02]}\end{array}$ \\
\hline
\end{tabular}

\subsection{Feeding}

Samples of each feed were collected and weighed to determine the mass contained in each recorded unit fed to each raceway segment. The Ziegler Slow sink had a mass of 844 g/unit and the Floating feed had a mass of 623 g/unit. Two samples of the VegiPRO® were weighed. One was collected at the beginning of the season and one at the end. The values were 650.75 g/unit and 646.0 g/unit, respectively.

Table 4.5 is a summary of the total feed put into each raceway segment between every monthly sampling period. Overall, the mass of VegiPRO® fed was less due to its lower density and a limited volume in the demand feeders. The feeding quantity and frequency were increased during the months when the fish were in the optimum growth temperature range. 
Table 4.5 Summary of Total Feed Applied to Each Raceway Segment

\begin{tabular}{|c|c|c|c|c|c|c|}
\hline \multirow[b]{2}{*}{$\begin{array}{l}\text { Time } \\
\text { Period }\end{array}$} & \multicolumn{3}{|c|}{ Side A (kg) } & \multicolumn{3}{|c|}{ Side B (kg) } \\
\hline & 1 & 2 & 3 & 1 & 2 & 3 \\
\hline $\begin{array}{c}10 / 15 / 03- \\
11 / 17 / 03\end{array}$ & 73.83 & 82.28 & 66.47 & 76.74 & 81.01 & 74.56 \\
\hline $\begin{array}{c}11 / 18 / 03- \\
12 / 18 / 03\end{array}$ & 62.46 & 78.49 & 70.90 & 68.98 & 75.49 & 65.73 \\
\hline $\begin{array}{c}12 / 19 / 03- \\
1 / 20 / 04\end{array}$ & 61.61 & 59.92 & 63.30 & 44.90 & 52.71 & 45.55 \\
\hline $\begin{array}{c}\text { 1/21/04 - } \\
\text { 2/20/04 }\end{array}$ & 33.76 & 34.60 & 30.38 & 23.43 & 26.03 & 20.82 \\
\hline $\begin{array}{c}\text { 2/21/04 - } \\
3 / 22 / 04\end{array}$ & 102.12 & 112.25 & 102.97 & 77.44 & 89.15 & 80.69 \\
\hline $\begin{array}{c}\text { 3/23/04 - } \\
4 / 23 / 04\end{array}$ & 178.08 & 181.46 & 169.64 & 141.21 & 137.96 & 122.34 \\
\hline $\begin{array}{c}4 / 24 / 04- \\
5 / 24 / 04\end{array}$ & 236.20 & 219.36 & 217.67 & 186.69 & 185.40 & 164.08 \\
\hline $\begin{array}{c}5 / 25 / 04- \\
5 / 30 / 04\end{array}$ & 38.74 & 7.96 & 4.80 & 31.65 & 27.78 & 7.75 \\
\hline $\begin{array}{c}\text { Season } \\
\text { Total }\end{array}$ & 786.80 & 776.32 & 726.13 & 651.04 & 675.53 & 581.52 \\
\hline
\end{tabular}

\subsection{Fish Sampling}

\subsubsection{Inventories and Overall Production}

Fish inventory was taken on three occasions: initial stocking, midway through the study, and at harvest. The dates of inventory are presented in Table 4.6. The number of fish and total mass in each raceway segment was determined from a sample population and the total weight of the raceway. These results are summarized in Tables 4.6 and 4.7. There is about a $10 \%$ reduction in inventory between stocking and the inventory conducted in the middle of the season. Some of this was attributed to theft prior to the installation of security measures. The mortalities in each raceway segment are also presented in the following table to demonstrate the differences 
between what was stocked and what was harvested. The recorded mortalities do not account for the change in population from the beginning of the study to the end.

Table 4.6 Summary of Inventory Results from Stocking to Harvesting - Population

\begin{tabular}{ccccccccc}
\hline \multicolumn{1}{c}{ A (\#) } & \multicolumn{4}{c}{ B (\#) } \\
\hline Date & $\mathbf{1}$ & $\mathbf{2}$ & $\mathbf{3}$ & Total & $\mathbf{1}$ & $\mathbf{2}$ & $\mathbf{3}$ & Total \\
\hline $10 / 8 / 2003$ & 1104 & 1105 & 1105 & 3314 & 1105 & 1106 & 1106 & 3317 \\
$1 / 20 / 2004$ & 1001 & 990 & 873 & 2864 & 997 & 1033 & 759 & 2789 \\
$5 / 24 / 2004$ & 833 & 876 & 764 & 2473 & 790 & 836 & 624 & 2250 \\
Mortalities & 137 & 175 & 144 & 456 & 167 & 204 & 157 & 528 \\
\hline
\end{tabular}

Table 4.7 Summary of Inventory Results from Stocking to Harvesting - Total Mass

\begin{tabular}{ccccccccc}
\hline \multicolumn{1}{c}{ A (kg) } & \multicolumn{4}{c}{ B (kg) } \\
\hline Date & $\mathbf{1}$ & $\mathbf{2}$ & $\mathbf{3}$ & Total & $\mathbf{1}$ & $\mathbf{2}$ & $\mathbf{3}$ & Total \\
\hline 10/8/2003 & 98.3 & 98.3 & 98.3 & 294.9 & 100.6 & 100.6 & 100.6 & 301.8 \\
5/29/2004 & 416.0 & 444.0 & 436.0 & 1296.0 & 354.0 & 375.0 & 289.0 & 1018.0 \\
Net Gain & 317.7 & 345.7 & 337.7 & 1001.1 & 253.4 & 274.4 & 188.4 & 716.2 \\
\hline
\end{tabular}

Several different metrics were considered to determine performance in each raceway segment and for comparison between the two different diets. These variables are defined in by Equations 4.1-4.5. The values calculated for each are provided in Table 4.8.

Feed Conversion Ratio (FCR):

$$
\text { FCR }=\frac{\text { Mass of Feed Applied to the System }}{\text { Final Fish Mass }- \text { Initial Fish Mass }}
$$

Equation 4.1

Mortality Adjusted Feed Conversion Ratio (MAFCR):

$$
\text { MAFCR }=\frac{\text { Mass of Feed Applied to the System }}{(\text { Final Fish Mass }+ \text { Mass of Mortalities })-\text { Initial Fish Mass }}
$$

Equation 4.2

Average Absolute Growth Rate (GR):

$$
\text { GR }=\frac{\text { Final Fish Mass }- \text { Initial Fish Mass }}{\text { \#Days in Study }}
$$

Equation 4.3 
Survival Rate:

$$
\text { Survival }=\frac{\# \text { Fish Harvested }}{\# \text { Fish Stocked }} \times 100
$$

Total Net Production (TNP):

$$
T N P=\sum\left(M_{i}-M_{o}\right)
$$

where $\mathrm{M}_{\mathrm{i}}$ is the total mass of fish in each segment, $\mathrm{i}$, at harvest.

\begin{tabular}{|c|c|c|c|c|c|c|c|c|}
\hline \multirow[b]{2}{*}{ Parameter } & \multicolumn{4}{|c|}{$\mathbf{A}$} & \multicolumn{4}{|c|}{ B } \\
\hline & 1 & 2 & 3 & Average & 1 & 2 & 3 & Average \\
\hline $\begin{array}{l}\text { FCR (kg feed/ } \\
\text { kg growth }\end{array}$ & 2.48 & 2.25 & 2.15 & 2.29 & 2.57 & 2.46 & 3.09 & 2.66 \\
\hline $\begin{array}{c}\text { MAFCR } \\
\text { (kg feed/ kg } \\
\text { growth) }\end{array}$ & 2.12 & 1.85 & 1.80 & 1.91 & 2.14 & 1.98 & 2.37 & 2.14 \\
\hline GR (kg/day) & 1.69 & 1.89 & 1.81 & 4.54 & 1.49 & 1.54 & 1.55 & 3.29 \\
\hline Survival (\%) & & -- & & 80.1 & & -- & & 80.7 \\
\hline TNP (kg) & & -- & & 1001 & & -- & & 716 \\
\hline
\end{tabular}

Table 4.8 Overall Summary of System Performance and Production.

The FCR and survival rates for Sides A and B are very similar: FCR $=2.29$ and 2.66, Survival = $80.1 \%$ and $80.7 \%$, respectively. The greatest difference is seen in the average absolute growth rate with values of $4.54 \mathrm{~kg} /$ day and $3.29 \mathrm{~kg} /$ day in $\mathrm{A}$ and $\mathrm{B}$, respectively. The total net production was also greater for Side A at 1001 kg; Side B yielded 716 kg.

\subsubsection{Length}

During monthly sampling, the length of each fish sampled was recorded. The average lengths for each month for both sides of the raceway are plotted in Figure 4.6. It can be seen that 
the fish in Side A were longer throughout the project. The average growth for both sides was $12.5 \mathrm{~cm}$. The maximum difference in length occurred April and was less than $2 \mathrm{~cm}$.

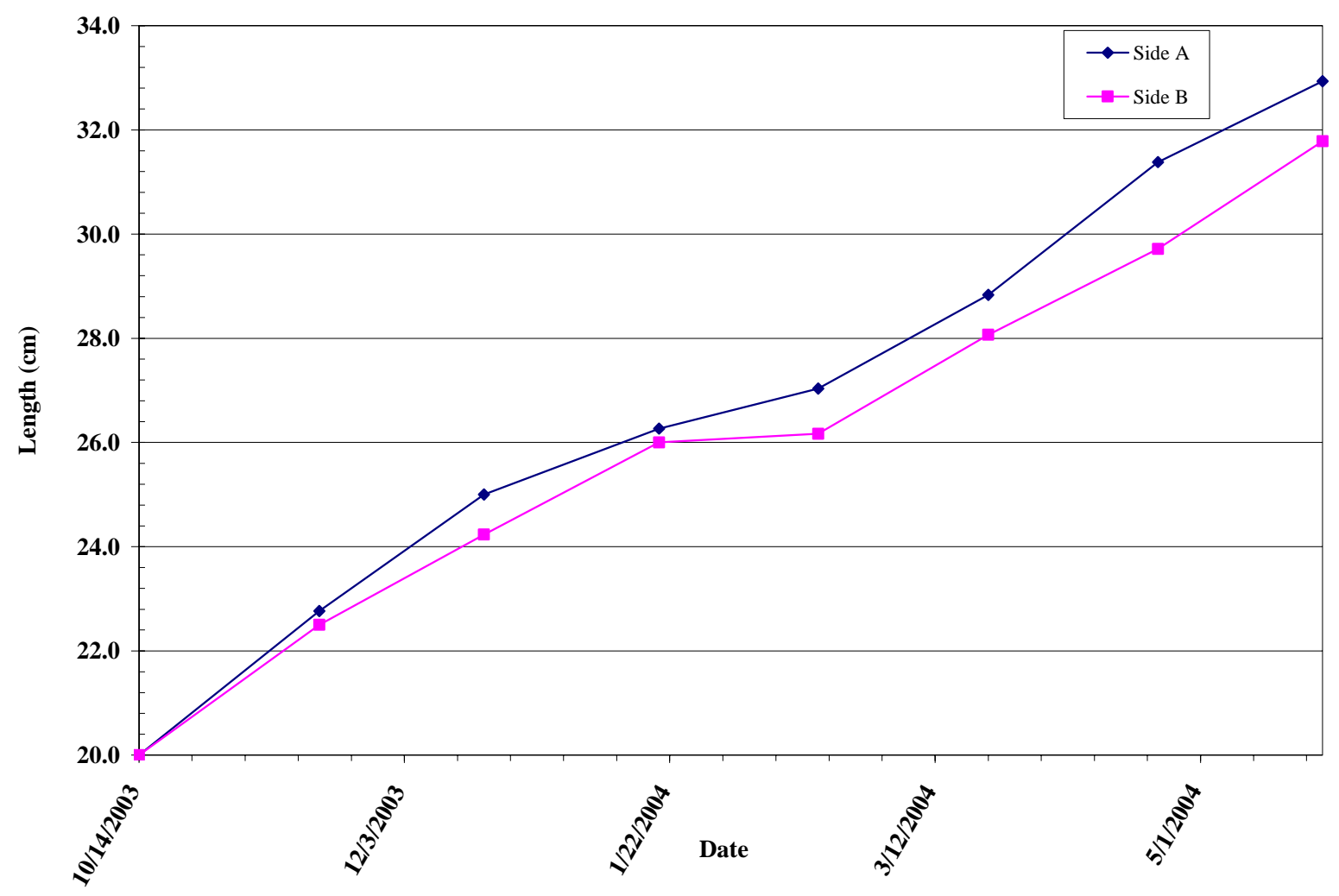

Figure 4.6 Comparison of Sampled Fish Length Between Two Feed Treatments.

The rate of increase reduces during the coldest months of the season, December through February. This is obvious from the change in slope of the growth curve, and can be seen even more clearly in Figure 4.7, which is a plot of the rate of growth in length for both sides of the raceway. 


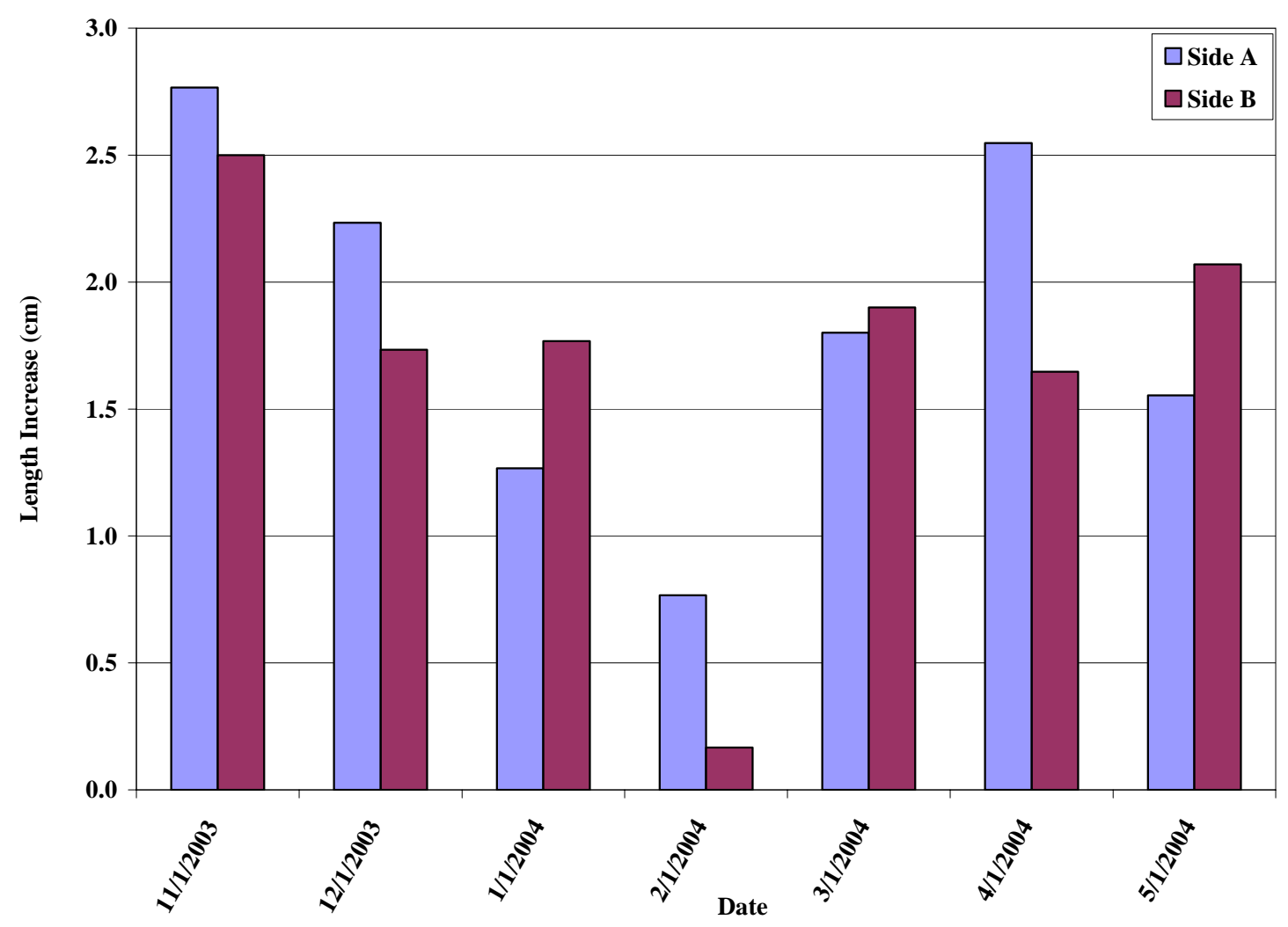

Figure 4.7 Comparison of Length Increase Between Two Feed Treatments.

The greatest increase in length for both sides occurred in November and April at an average of $2.6 \mathrm{~cm}$ and $2.1 \mathrm{~cm}$, respectively. As expected these growth rates occurred during the months with the greatest amount of time in the optimal growth range. As mentioned previously, February had the lowest growth rate at an average of $0.5 \mathrm{~cm}$. Complete fish sampling data are presented in Table B.12.

\subsubsection{Weight}

Similar to the growth of the fish in length, the weight of each fish in the monthly sampling was determined and is plotted in Figure 4.8. Overall there was a greater increase in weight over the study period for Side A with an average final weight per fish of 482 g; Side B had an average final weight of 430g per fish. The average initial weight of both sides was $89 \mathrm{~g}$ per fish. 


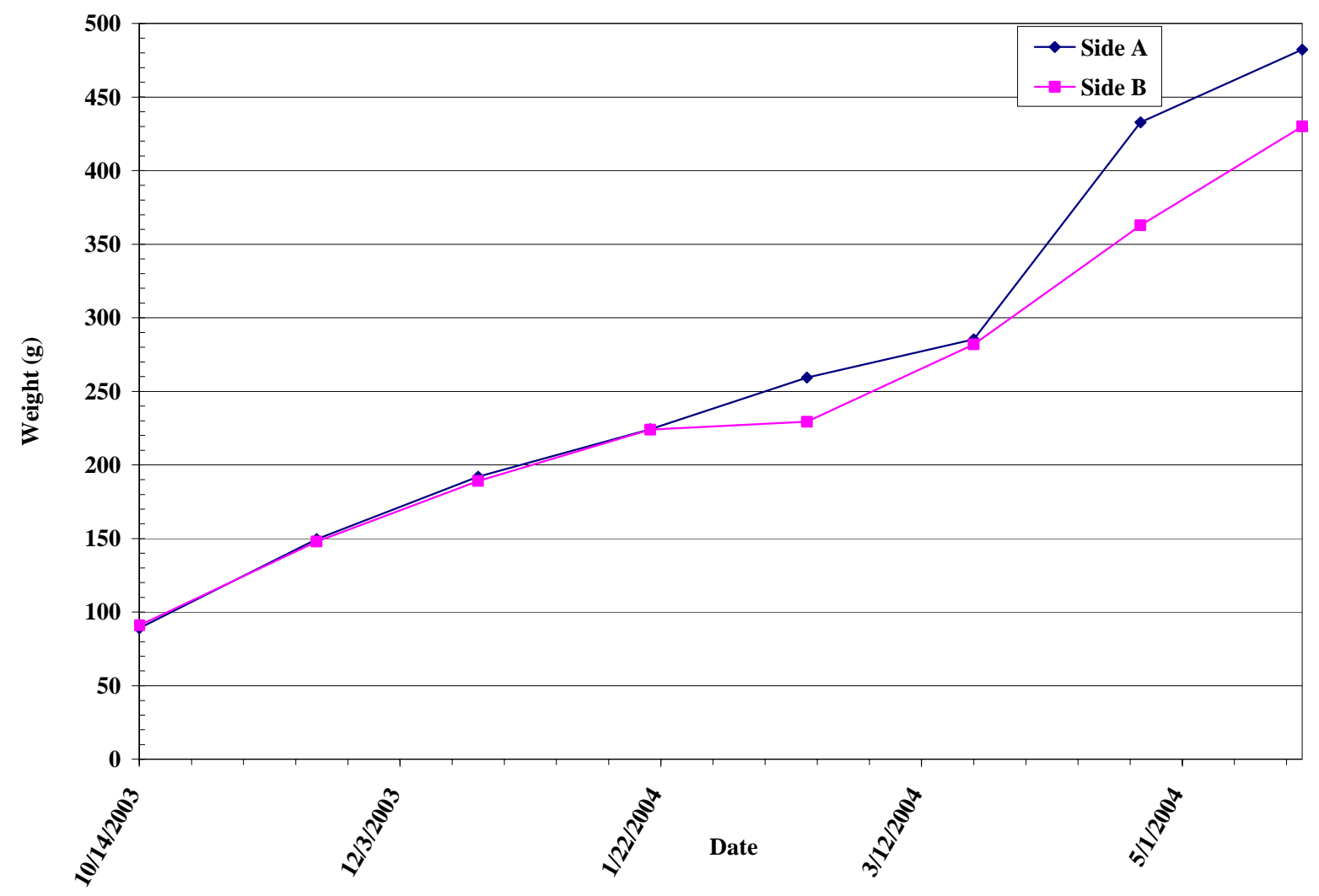

Figure 4.8 Comparison of Sampled Fish Weight Between Two Feed Treatments.

Again, the growth rates, change in weight/time, declined during the coldest periods. The rate of weight change also leveled off towards the end of the study as temperatures exceeded the optimal growth range. These trends are presented in Figure 4.9, which is a comparison of the amount of weight gained per day in each side of the raceway. The greatest gain in a single month was achieved in Side A during the month of April at $4.6 \mathrm{~g} /$ day per fish. The lowest rate of weight gain occurred in Side B in February at 0.2 g/day per fish. 


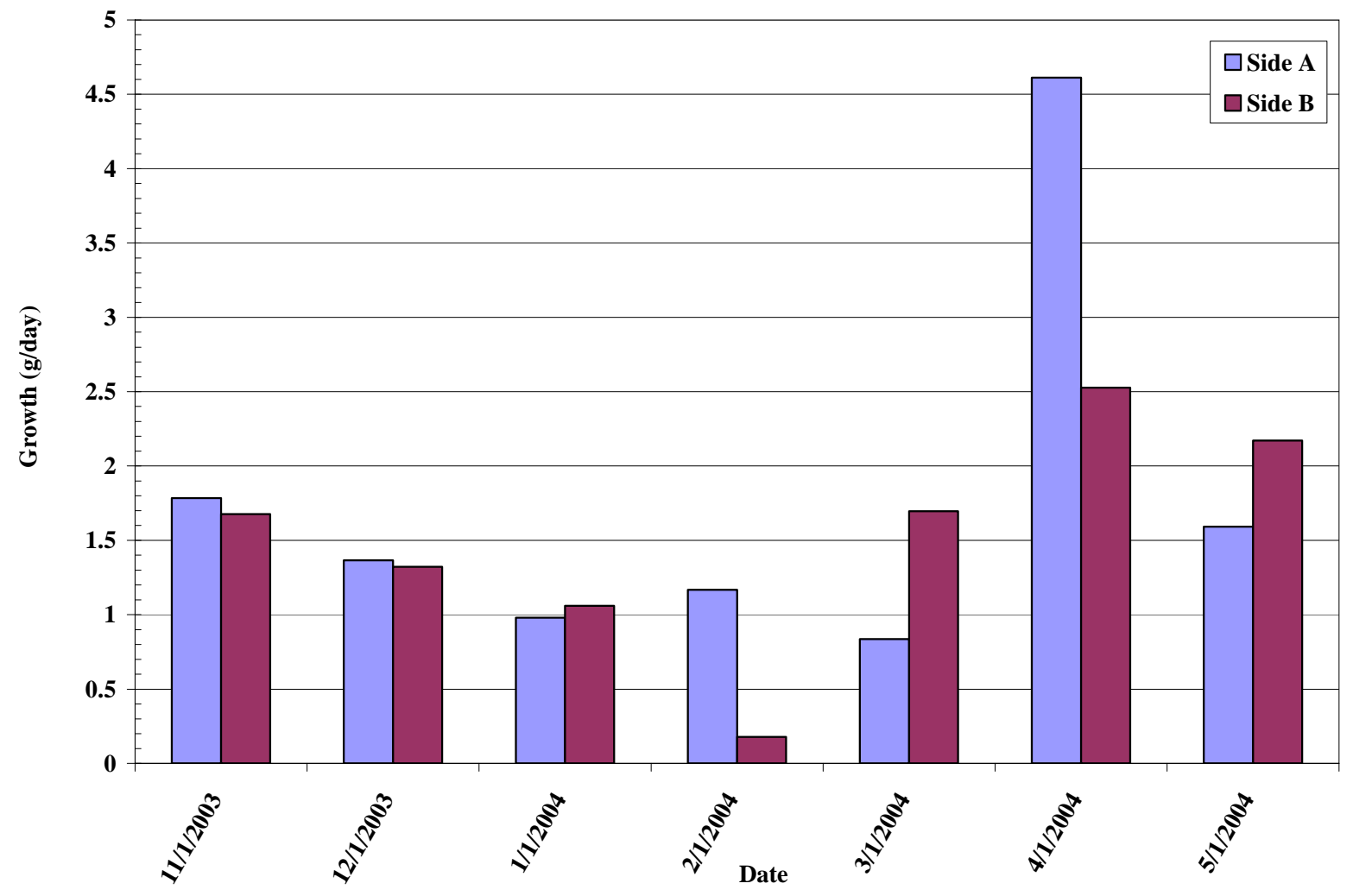

Figure 4.9 Comparison of Fish Growth Rate Between Two Feed Treatments.

\subsection{Aqua-sludge}

\subsubsection{Total Solids}

During the aqua-sludge sampling, the total volume recorded was used to determine the total amount of solids produced for a single raceway segment in a 24-hour period. These values for the four successful sampling efforts are displayed in Figure 4.10. Side A, the Ziegler diet, consistently produced a greater quantity of solid waste ranging from 846 to $2092 \mathrm{~g}$. The least amount of solids produced by Side B was 492 g on January 28, 2004, during a low growth time. 


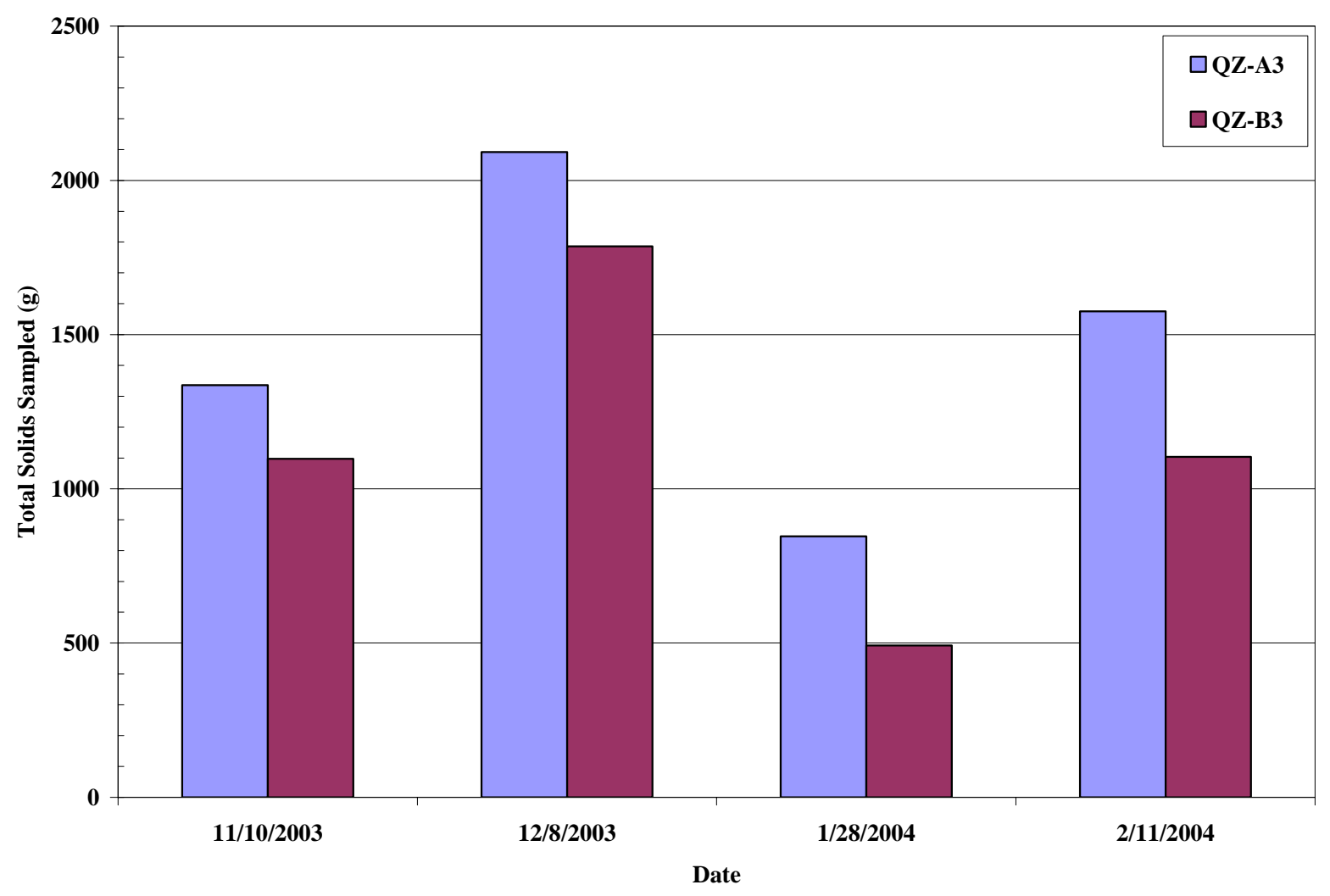

Figure 4.10 Comparison of Solids Produced for Two Feed Treatments.

\subsubsection{Nutrients and $\mathrm{BOD}_{5}$}

A summary of the nutrient analysis results and $\mathrm{BOD}_{5}$ of the aqua-sludge samples is provided in Table 4.9. Side A, the Ziegler diet, had a higher concentration of nutrients and $\mathrm{BOD}_{5}$ than Side B. Complete aqua-sludge data are presented in Table B.13 and.

Table 4.9 Summary of Nutrient Content and $\mathrm{BOD}_{5}$ of Aqua-sludge Samples.

\begin{tabular}{|c|c|c|c|c|c|}
\hline $\begin{array}{c}\text { Sample } \\
\text { Location }\end{array}$ & $\begin{array}{c}\mathrm{NO}_{2}(\mathrm{mg} / \mathrm{L}) \\
\text { average } \\
\text { [range] }\end{array}$ & $\begin{array}{c}\mathrm{NO}_{3}(\mathrm{mg} / \mathrm{L}) \\
\text { average } \\
\text { [range] }\end{array}$ & $\begin{array}{c}\text { TAN (mg/L) } \\
\text { average } \\
\text { [range] }\end{array}$ & $\begin{array}{c}\text { TP }(\mathrm{mg} / \mathrm{L}) \\
\text { average } \\
\text { [range] }\end{array}$ & $\begin{array}{c}\text { BOD }_{5}(\mathrm{mg} / \mathrm{L}) \\
\text { average [range] }\end{array}$ \\
\hline QZ-A3 & $\begin{array}{c}0.04 \\
{[<.01-.04]}\end{array}$ & $\begin{array}{c}0.13 \\
{[.12-.15]}\end{array}$ & $\begin{array}{c}6.61 \\
{[5.08-8.13]}\end{array}$ & $\begin{array}{c}45.7 \\
{[34.9-56.4]}\end{array}$ & $\begin{array}{c}1794 \\
{[1582-2263]}\end{array}$ \\
\hline QZ-B3 & $\begin{array}{c}0.02 \\
{[<.01-.02]}\end{array}$ & $\begin{array}{c}0.13 \\
{[.12-.15]}\end{array}$ & $\begin{array}{c}3.86 \\
{[2.9-4.81]}\end{array}$ & $\begin{array}{c}22.7 \\
{[15.1-30.2]}\end{array}$ & $\begin{array}{c}1083 \\
{[819-1430]}\end{array}$ \\
\hline
\end{tabular}




\subsection{Water Quality Disturbance Events}

On two occasions in the study period, a significant change in water quality was observed. These events occurred on March 10, 2004 and April 14, 2004. They were noticed initially by spikes in turbidity during weekly field monitoring. During the second event, additional grab samples were collected to identify the extent of the change and cause of the problem. The parameters affected most significantly were turbidity, total suspended solids, and total metal concentrations. This was previously reported for turbidity in Figure 4.4. A summary of the water quality during the second of these events is presented in Table 4.10.

Table 4.10 Summary of Water Quality Disturbance Values.

\begin{tabular}{ccc}
\hline Parameter & $\begin{array}{c}\text { Mean } \pm \text { Std. } \\
\text { Dev, 2003-2004 }\end{array}$ & $\begin{array}{c}\text { Disturbance, } \\
\mathbf{4 / 1 4 / 2 0 0 4}\end{array}$ \\
\hline pH, standard units & $8.00 \pm 0.16$ & 7.75 \\
Specific Conductance, mS/cm & $6.21 \pm 0.25$ & 6.25 \\
Dissolved Oxygen, mg/L & $10.43 \pm 0.96$ & 9.68 \\
Turbidity, NTU & $5.6 \pm 4.9$ & 46.7 \\
TSS, mg/L & $4 \pm 2$ & 8 \\
Total Ammonia-Nitrogen, & $2.34 \pm 0.16$ & 2.53 \\
mg/L & $3100 \pm 400$ & 3300 \\
Sulfate, mg/L & $333 \pm 90$ & 355 \\
Alkalinity, mg/L as CaCO 3 & $14 \pm 5$ & 19 \\
Acidity, mg/L as CaCO & & \\
\hline
\end{tabular}

Additionally, the dissolved and total metal concentrations were determined. The results of these analyses are presented in Table 4.11. Although the dissolved metal levels were all within acceptable limits during the disturbance, the total iron level was significantly greater than the historical and recommended levels. 
Table 4.11 Summary of Water Quality Disturbance Metal Concentrations.

\begin{tabular}{ccc}
\hline & $\begin{array}{c}\text { Historical Values } \\
\text { Mean } \pm \text { Std. Dev. }\end{array}$ & $\begin{array}{c}\text { Disturbance, } \\
\mathbf{4 / 1 4 / 2 0 0 4}\end{array}$ \\
\hline Dissolved Iron, mg/L & $0.1 \pm 0.1$ & 0.1 \\
Dissolved Aluminum, mg/L & $0.06 \pm 0.02$ & 0.05 \\
Dissolved Manganese, mg/L & $0.32 \pm 0.13$ & 0.64 \\
Dissolved Calcium, mg/L & $348 \pm 33$ & 360 \\
Dissolved Magnesium, mg/L & $85 \pm 35$ & 86 \\
Total Iron, mg/L & $0.5 \pm 0.2$ & 3.1 \\
Total Aluminum, mg/L & $0.2 \pm 0.1$ & 0.1 \\
Total Manganese, mg/L & $0.82 \pm 0.42$ & 0.66 \\
Total Calcium, mg/L & $454 \pm 25$ & 370 \\
Total Magnesium, mg/L & $124 \pm 12$ & 88 \\
\hline
\end{tabular}




\section{CHAPTER 5. DISCUSSION}

\subsection{Feed Comparison - Before Disturbance Events}

\subsubsection{Water Quality}

Prior to the disturbance events, no statistically significant difference in water quality was observed between the two sides of the raceway for any of the field monitoring or grab sample analyses. Complete water quality are presented in Tables B1-B11. Also, all active concentrations remained within the recommended limits for rainbow trout. Specifically, ammonia and metals levels were within acceptable levels after the values determined by analysis were adjusted based on $\mathrm{pH}$, temperature, and ionic strength. The active values for unionized ammonia are also presented in the tables in the appendices.

Discussion of one other water quality parameter, DO, is also necessary. Although, as previously stated in this section, there was no statistically significant difference in DO levels between the two sides of the raceway, Side A did have consistently lower levels, as presented in Figure 4.2. There are two possible explanations for this. First, Side A had slightly lower flow rates, approximately 2.2\% less on average. Second, Side A had an overall greater density of fish throughout the study, as seen in Tables 4.6 and 4.7.

\subsubsection{Feed Conversion}

Comparison of the feed conversion ratios (FCR) for Sides A and B indicates that there is a statistically significant difference in the values reported in Table 4.8. Based on the overall FCR, Side A, Ziegler feed diet, required $0.37 \mathrm{~kg}$ of feed less than Side B, VegiPro® diet, for each kg of weight gained by the population. Stated differently, 16\% more VegiPro ${ }^{\circledR}$ feed, by weight, is required to produce the same growth as the Ziegler feed. These values are consistent with those provided previously in Table 2.5, a similar feed case study. In that study it was found 
that $23 \%$ more VegiPro ${ }^{\circledR}$ feed was required for the same growth. When comparing cost, units of $\$ /$ weight gained are most useful. The values calculated for the present study were $\$ 0.447 / \mathrm{kg}$ for the Ziegler diet and $\$ 0.459 / \mathrm{kg}$ for the VegiPro ${ }^{\circledR}$.

FCR and price are the values most commonly used when selecting a diet suitable for an aquaculture operation. However, for this study, a new variable has been defined. This value is the mortality adjusted feed conversion ratio (MAFCR). This variable was defined previously in Section 4.3.1 (Equation 4.2). The purpose of this new variable is to account for the weight gain produced by feed added to the system in the fish lost as mortalities. Under typical operations, this would be unnecessary; however, in this study, large mortalities ( 20\%) were encountered as a result of an event unrelated to the feed content or quantity. This causes the FCR, which is based only on the weight of surviving, harvested fish, to be deceptively higher than if the disturbance had not occurred. This value does not reflect the true performance of the feed in situations where excessive mortalities occur. Although the difference between the two feeds is not significantly different with this adjusted calculation, the values of both do produce more promising, and more accurate numbers. When comparing the MAFCR, Side A required $0.23 \mathrm{~kg}$ less feed per kg of weight gained. Again, this means that $12 \%$ more of the VegiPro ${ }^{\circledR}$ feed is needed than the Ziegler feed to produce the same overall weight gain.

\subsubsection{Waste Production}

The results of the aquasludge sampling where presented in Figure 4.9. From the statistical analysis of the data, the Ziegler diet (Side A) produced a significantly greater amount of solid waste than the VegiPro ${ }^{\circledR}$ diet (Side B) at an average of $38 \% \pm 24 \%$ more. Composition of the diet can play a large role in the waste production. Specifically, the level of carbohydrates, which are not utilized by the fish, and the ratio of digestible to crude protein can be adjusted to 
reduce waste production. However, the waste produced was not limited to the settled solids collected in the sludge sampling. Additional wastes that were not traceable by sampling methods employed include suspended solids and liquid or soluble wastes generated from the feed. Also relevant in feed to waste comparison is the efficiency of feed to energy conversion. This too is influenced by feed composition and can affect feed performance.

A complete analysis of the fate of the feed components was not conducted due to incomplete data. Instead, an overall mass balance was calculated for the raceway segments where sludge sampling was performed, A3 and B3. The equations used for this calculation are presented below as Equations 5.1 and 5.2. A summary of these calculations is provided in Table 5.1. For accounting purposes, the mass of feed converted to energy used by the fish for biological processes, the suspended solids, and the liquid or soluble wastes are recorded as one value. The percentage of the feed represented by each output is also presented.

$$
\begin{gathered}
M_{\text {in }}=M_{\text {out }} \\
M_{F}=M_{G}+M_{A}+M_{E}+M_{S}+M_{D}
\end{gathered}
$$

where,

$$
\begin{aligned}
& M_{F}=\text { mass of feed supplied to segment at beginning of sample period } \\
& M_{A}=\text { mass of waste collected as aqua-sludge } \\
& M_{G}=\text { mass gained by fish during sample period } \\
& M_{E}=\text { mass of feed converted to energy by fish } \\
& M_{S}=\text { mass of uneaten feed and waste as suspended solids } \\
& M_{D}=\text { mass of uneaten feed and waste as dissolved solids }
\end{aligned}
$$


Table 5.1 Summary of Mass Balance Calculations.

\begin{tabular}{|c|c|c|c|c|c|c|c|}
\hline & \multicolumn{7}{|c|}{ A3 (grams) } \\
\hline $\begin{array}{c}\text { Sample } \\
\text { Date }\end{array}$ & $\mathbf{M}_{\mathbf{F}}$ & $\mathbf{M}_{\mathbf{G}}$ & \% of $\mathbf{M}_{\mathbf{F}}$ & $\mathbf{M}_{\mathbf{A}}$ & \% of $\mathbf{M}_{\mathbf{F}}$ & $\mathbf{M}_{\mathbf{E}}+\mathbf{M}_{\mathbf{S}}+\mathbf{M}_{\mathbf{D}}$ & \% of $\mathbf{M}_{\mathbf{F}}$ \\
\hline $11 / 10 / 2003$ & 6752 & 3965 & 59 & 1336 & 20 & 1451 & 21 \\
\hline $12 / 8 / 2003$ & 7596 & 3921 & 52 & 2092 & 28 & 1583 & 21 \\
\hline $1 / 28 / 2004$ & 4225 & 2277 & 54 & 846 & 20 & 1102 & 26 \\
\hline $2 / 11 / 2004$ & 5915 & 2277 & 38 & 1576 & 27 & 2062 & 35 \\
\hline \multicolumn{7}{|c|}{ Bample (grams) } \\
\hline Date & $\mathbf{M}_{\mathbf{F}}$ & $\mathbf{M}_{\mathbf{G}}$ & \% of $\mathbf{M}_{\mathbf{F}}$ & $\mathbf{M}_{\mathbf{A}}$ & \% of $\mathbf{M}_{\mathbf{F}}$ & $\mathbf{M}_{\mathbf{E}}+\mathbf{M}_{\mathbf{S}}+\mathbf{M}_{\mathbf{D}}$ & \% of $\mathbf{M}_{\mathbf{F}}$ \\
\hline $11 / 10 / 2003$ & 6508 & 3773 & 58 & 1097 & 17 & 1638 & 25 \\
\hline $12 / 8 / 2003$ & 6508 & 2783 & 43 & 1786 & 27 & 1939 & 30 \\
\hline $1 / 28 / 2004$ & 2603 & 1140 & 44 & 492 & 19 & 971 & 37 \\
\hline $2 / 11 / 2004$ & 3254 & 1140 & 35 & 1104 & 34 & 1010 & 31 \\
\hline
\end{tabular}

The feed input was the total feed supplied to the system the two days prior to the sampling event. The solid waste in the quiescent zone was removed prior to feeding on the first of these two days. For these calculations, it was assumed that all the feed placed in the feeders during these two days was dispensed and either eaten or settled as solid waste. A more rigorous balance, including all major constituents in the feed, could be conducted in future investigations with a more controlled experimental design, a more strategic sampling plan, and with more accurate and detailed record keeping.

\subsection{Impact of Disturbance Events}

\subsubsection{Growth Rate}

The average monthly growth rates by length and weight for both sides were presented in Figures 4.6 and 4.8, respectively. Although fish in Side A were consistently larger than Side B, on average, there was no statistically significant difference in the rates of growth between the two populations, by length or by weight. 
The growth by weight results are presented again below in Figure 5.1, along with a plot of the average monthly temperature. This figure was created to demonstrate the affect of water temperature on the growth rate. It was previously determined (Viadero and Tierney, 2003) that water temperature has the greatest impact on the rate of growth. The highest growth rate was observed in April when the temperature was within the optimal growth range of $10-15.6^{\circ} \mathrm{C}$ for the entire sampling period. Although the temperature also remained in this range for the majority of May, 2004, a decrease in the rate of growth was observed. This was largely attributed to the water quality disturbance event that occurred on April 14, 2004. The results of this event were presented in Tables 4.10 and 4.11 .

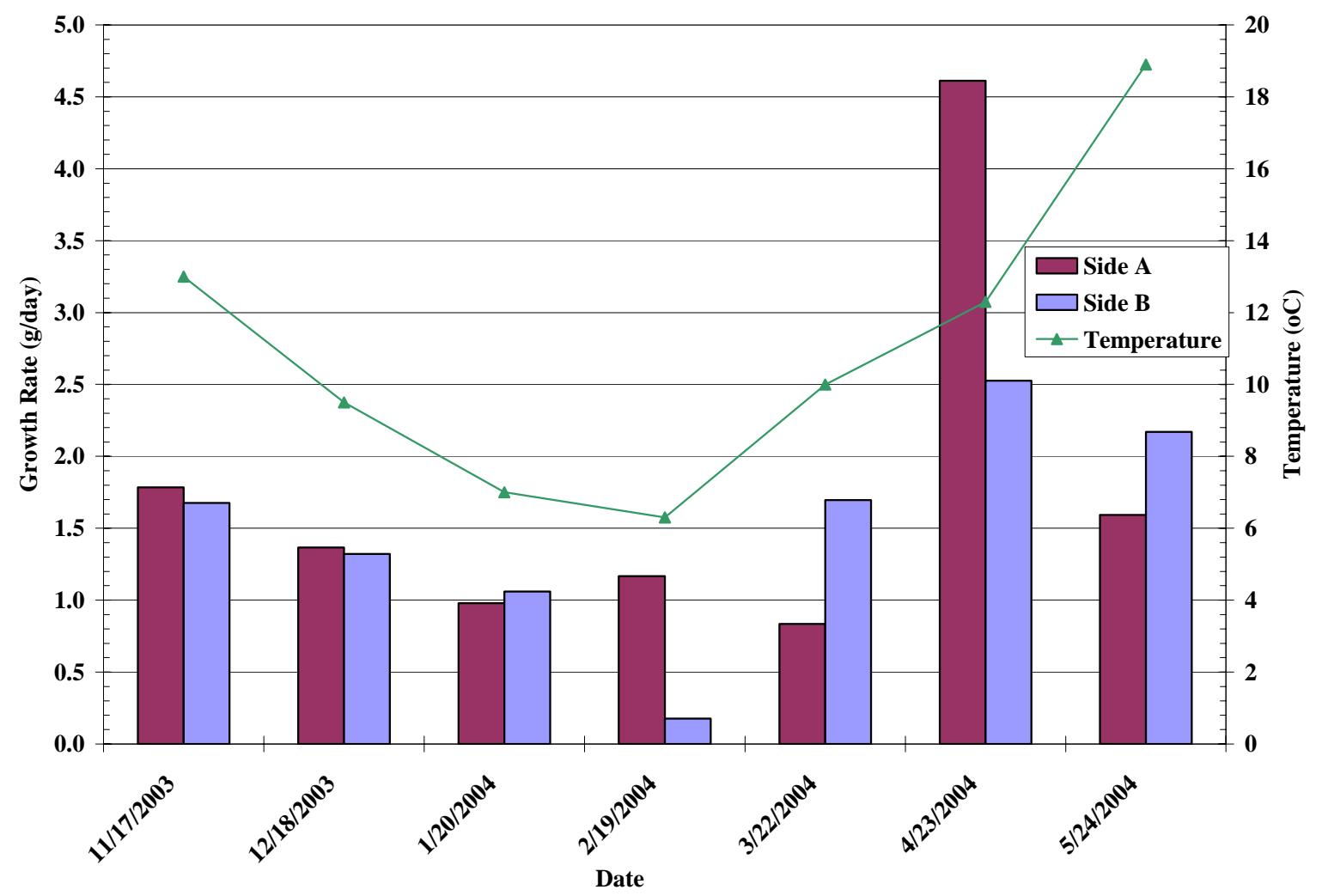

Figure 5.1 Growth Rate (Mass) Comparison for Two Feeds with Changing Temperature. 
The effect of the disturbance on the fish growth is further demonstrated in Figure 5.2. For this figure, the average monthly temperature was used with a temperature unit growth model (Soderberg, 1995) to predict the expected growth rate in length. These values are plotted along with the actual measured growth rates. The equation used for this model prediction is presented as Equation 5.3 where $\mathrm{L}$ is in units of $\mathrm{mm} /$ day and $\mathrm{T}$ is in units of ${ }^{\circ} \mathrm{C}$. This equation was selected because its temperature range of applicability was $7-16^{\circ} \mathrm{C}$.

$$
\Delta L=-0.040+0.505 T
$$

Equation 5.3

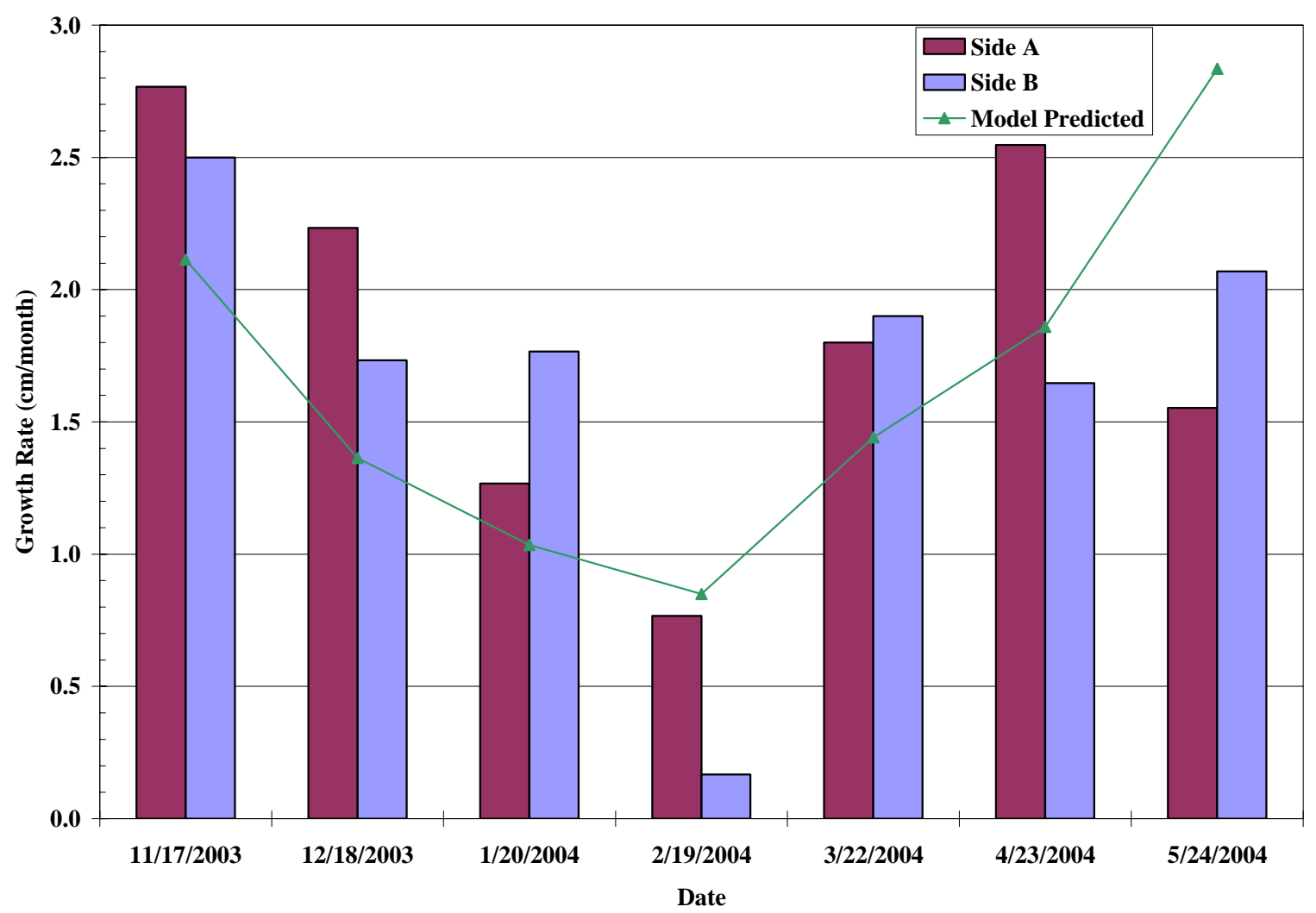

Figure 5.2 Growth Rate (Length) Comparison for Two Feeds with Changing Temperature.

Clearly, the growth rates were the lowest during February and May. In February, the temperatures were well below the optimum range. In May, as mentioned previously, the temperatures were within the optimum growth range; however, the disturbance event negatively 
impacted the growth because of the increased stress and consequently, the compromised health of the fish. These data are presented again below in Figure 5.3 with actual growth as a percent of predicted. Again, February and May were the only months with growth rates below the model predicted values.

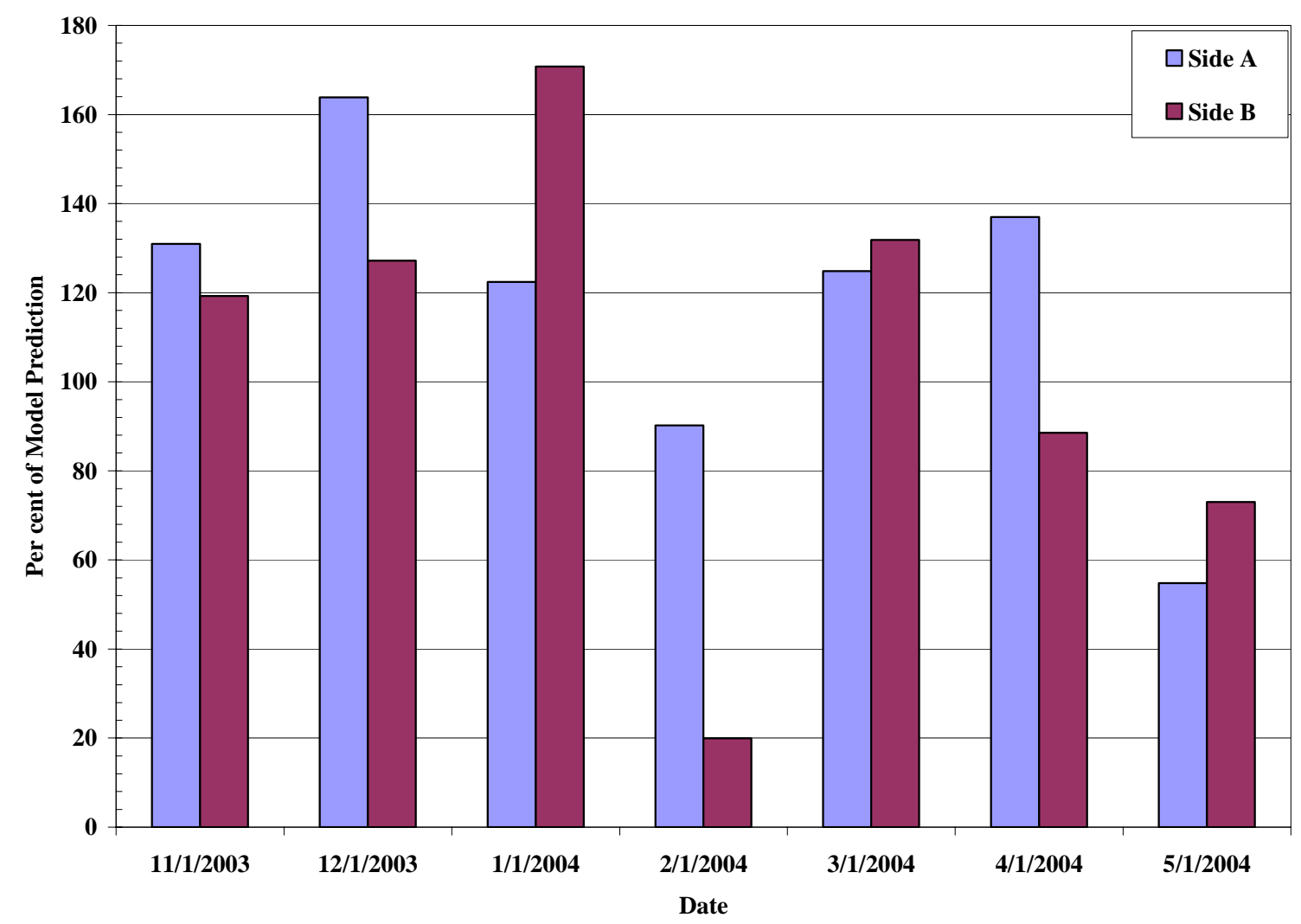

Figure 5.3 Growth Rate (Length) Comparison for Temperature Unit Model Prediction.

The growth model presented above was only used to predict the growth rate of the fish by length. In order to make a comparison based on weight, the condition factor, $\mathrm{K}$, was used to convert the length values to weight. These values are presented in Figure 5.4. The weight-based growth trends were consistent with the trends predicted for length. However, there are separate model predictions for each raceway segment. This is because the condition factors were 
different for each side; the length model only took into account temperature, which was the same for both sides. The condition factor is defined and discussed in the next section.

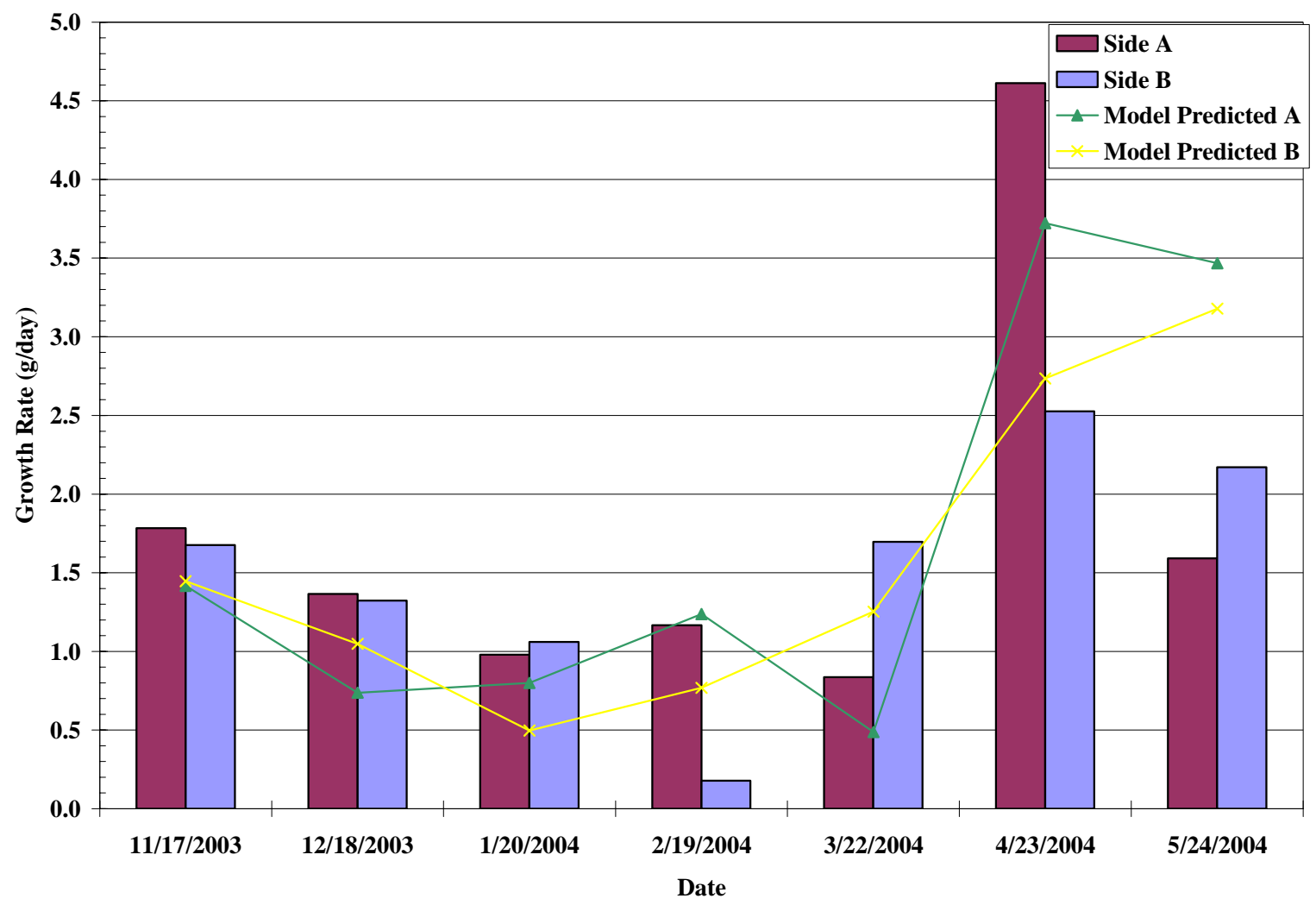

Figure 5.4 Growth Rate (Mass) Comparison for Temperature Unit Model Prediction Using K.

\subsubsection{Condition Factor}

The weight and length measurements were used to calculate the condition factor. The condition factor, $\mathrm{K}$, is a relationship between the weight and length of the fish and is used to determine the quality of the population for food use or recreational use. This is defined by Equation 5.4, and the results from all sampling are presented in Figure 5.5. Both sides had condition factors within the range of $0.011 \mathrm{~g} / \mathrm{cm}^{3}$ at the beginning of the study and $0.0145 \mathrm{~g} / \mathrm{cm}^{3}$ at the end. These values are indicative of appropriate size and quality for fish used as food. 
Condition Factor (K):

$$
K=\frac{\text { Weight }}{\text { Length }^{3}}
$$

Equation 5.4

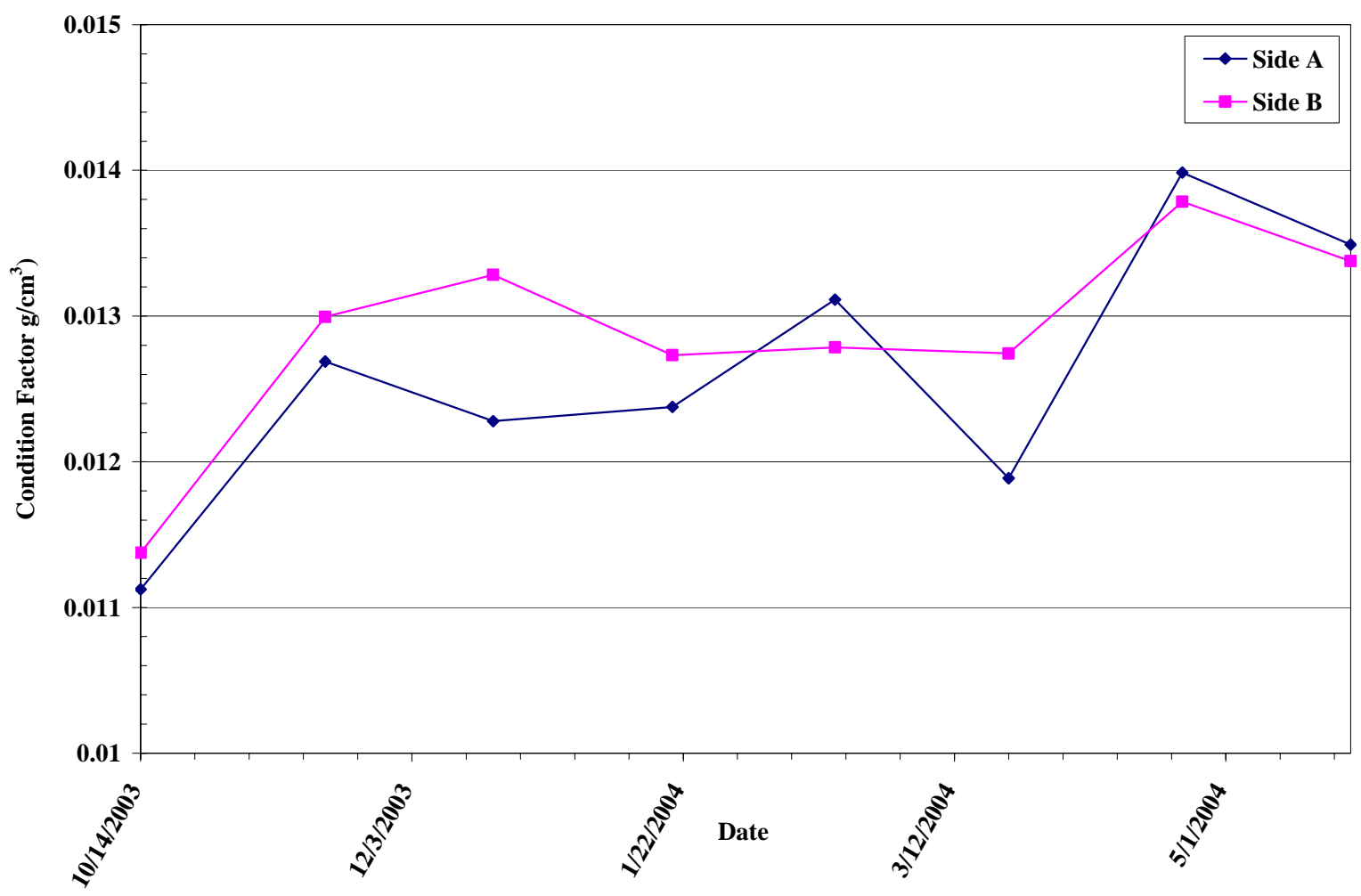

Figure 5.5 Comparison of Condition Factor Between Two Feed Treatments.

\subsubsection{Disease and Mortalities}

In addition to an adverse affect on the growth rates of the fish in both sides of the raceway, the disturbance events had a long term affect on the fish health and immunity, resulting in an infestation of disease and eventually high mortality rates. The disease was first identified during monthly inventory sampling from an increased occurrence of skin lesions typical of an aeromonas bacterial infection (Semmens). The Aeromonas Test Report is provided in Appendix C. A picture of a fish infected with this disease is presented in Figure 5.6. 


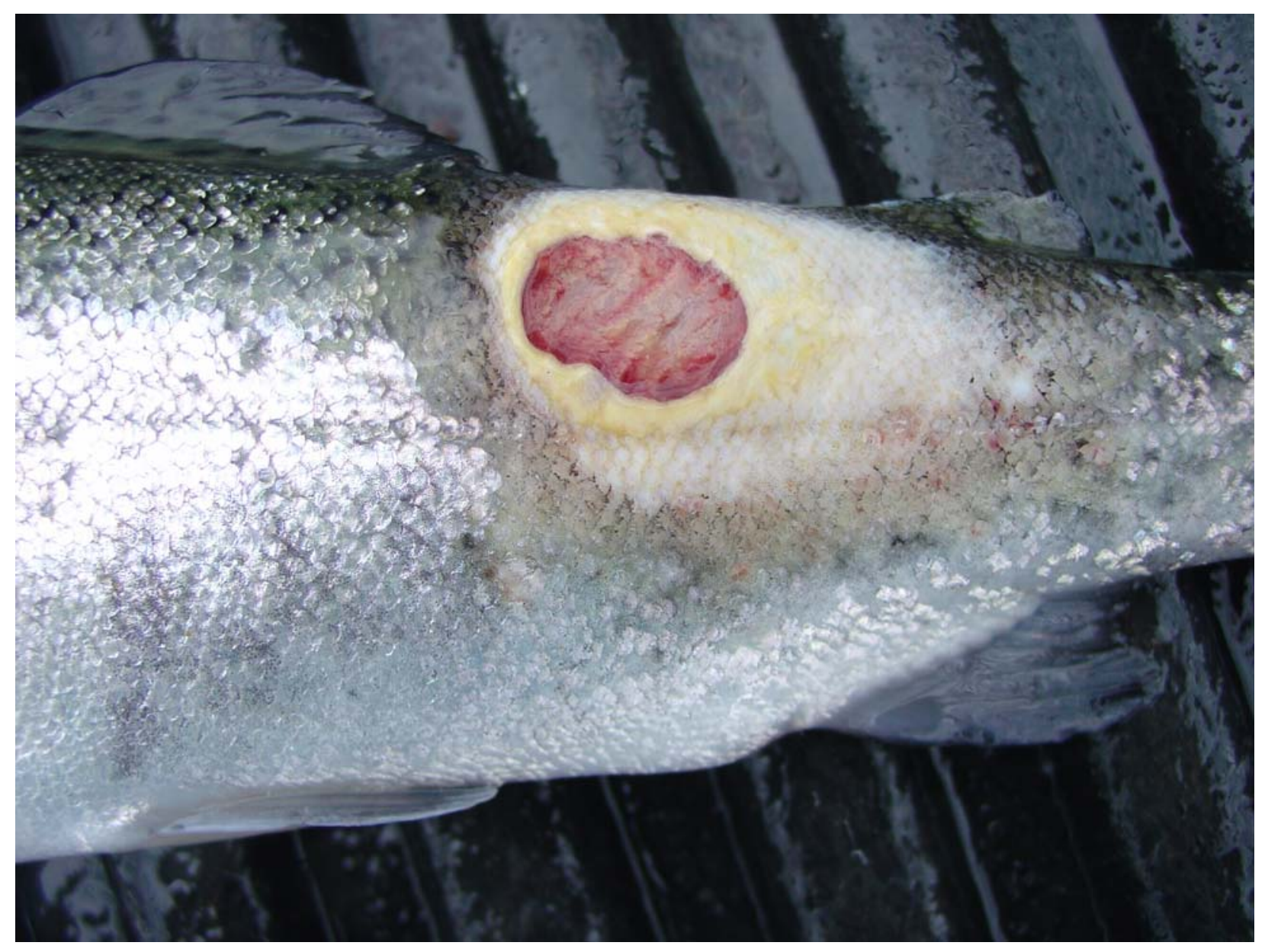

Figure 5.6 Photograph of Fish Infected by Aeromonas Bacteria.

Aeromonas infections are among the most common diseases to affect fish raised in aquaculture systems (Plumb, 1994). The bacteria are present in almost all natural water sources, but healthy fish are able to fight off an infection. When the fish health is compromised by any environmental factor, the immune system is weakened, and the disease is contracted. The water quality from a MWTF is below recommended standards and can put health of the fish in a weakened state. In this condition, stress events that healthy fish recover from can cause the population to succumb to the bacterial infection. Under certain circumstances, the aeromonas infection can lead to mortalities near 80 percent (Plumb, 1994). 
The mortality rates of this study were not drastic; however, an increase in the mortality rate late in the season was observed and has been attributed to the disturbance events reported. Presented in Figure 5.7 are the cumulative mortalities for both sides from the first disturbance event occurring on March 10, 2004. The second, more significant disturbance event occurred 33 days later on April 14, 2004. At that point on the graph is when the greatest increase in mortalities was recorded. Figure 5.8 is a plot of the average daily mortality rate for the entire season. Again, a sharp increase in these values can be seen after the second disturbance event. The health of the fish was strong enough to recover from the first event, but the severity of the second event, as well as the increasing water temperature, resulted in the inability of the population to resist the infection brought on by the aeromonas bacteria.

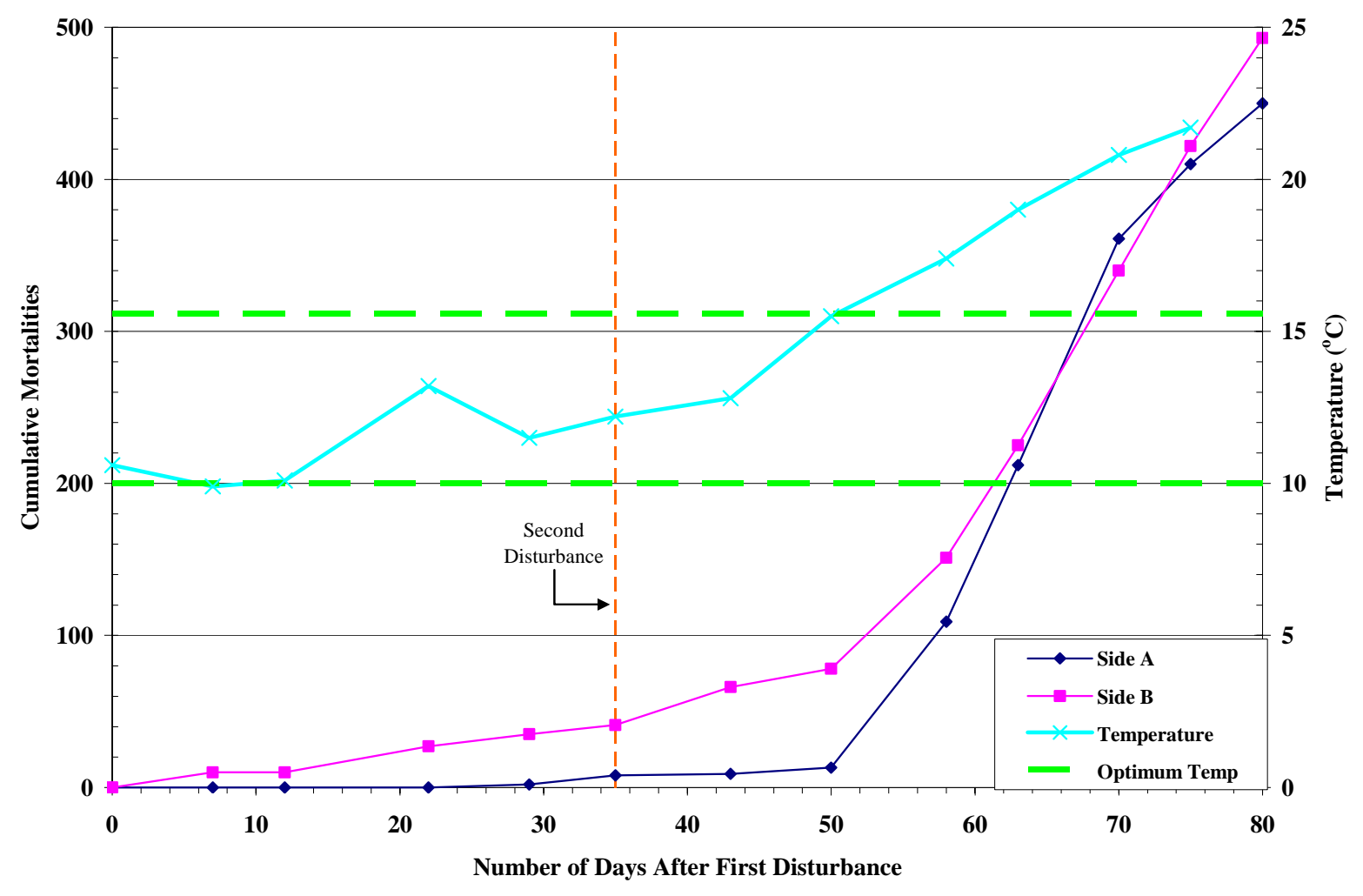

Figure 5.7 Plot of Cumulative Mortalities after Disturbance Events. 


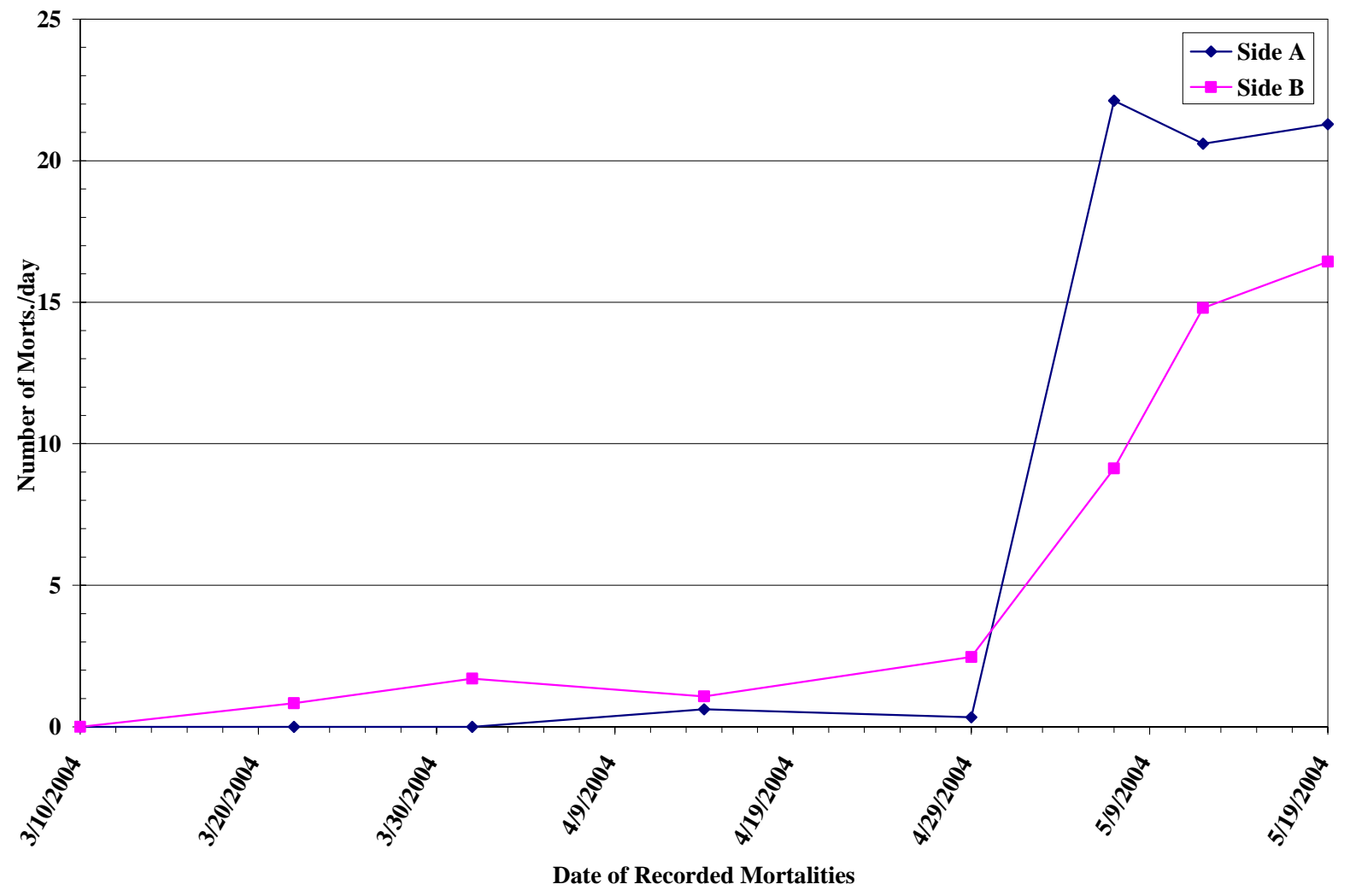

Figure 5.8 Plot of Increasing Rate of Mortalities per Day. 


\subsection{System Risk Assessment}

The feasibility of rearing rainbow trout in intensive aquaculture facilities supplied with treated mine water has been well demonstrated. Effluent from mine water treatment facilities (MWTF) have proven to be a suitable water resource for producing successful aquaculture operations where the fish do not exhibit the expected adverse response to the impaired water quality. However, there are two issues that have not been addressed sufficiently in peer reviewed research related to these operations. The first is the possibility that, although fish reared in these water sources appear to be healthy and grow to desired weights, the reduced water quality might put them in a health condition that is less resistive to the impacts of stress events common to all rearing facilities. Second, facilities utilizing treated mine water are at a higher risk of water quality disturbances than spring fed operations. This leaves the potentially weaker fish in a more vulnerable situation.

The first of these hypotheses would be very difficult to substantiate with the data collected in this study, or results reported in literature. Studies have not been conducted on the impact of disturbance events, similar in magnitude to the ones observed this season, on fish reared in typical water sources. It is possible that another population raised in higher quality water throughout the season would have suffered similar infections of aeromonas and similarly high mortality rates if exposed to the same increase of turbidity and iron concentrations. Nevertheless, further discussion on the specific differences in water quality and chemistry between treated mine water and natural water sources is warranted.

The most significant difference between the water quality supplied from a MWTF and other fresh water sources is the concentration of metals. The most abundant of these metals is typically iron. At levels $>0.1 \mathrm{mg} / \mathrm{L}$ metals in water are toxic to fish. In solution these metals are 
acidic causing the mine waters to have a low $\mathrm{pH}(<3)$. The method for removing these metals, precipitation and settling, was described in Section 2.2.2. This treatment method uses hydrated lime, which is believed to be the source of elevated levels of ammonia found in the water used in this study.

Ammonia is toxic to rainbow trout in its unionized form. The concentration is affected by the $\mathrm{pH}$, temperature, and ionic strength of the water; the equilibrium expression for this consituent is provided in Equation 5.5 .

$$
\mathrm{NH}_{3}+\mathrm{H}^{+} \leftrightarrow \mathrm{NH}_{4}^{+}
$$

Equation 5.5

Although ammonia is present in all aquaculture systems, systems using mine waters treated with hydrated lime will have to be more closely monitored. The concentrations of total ammonia nitrogen (TAN) measured for this study were presented in Table 4.3. These concentrations appear to be well above even the most conservative recommended level found in literature of 0.2 mg/L (Colt and Armstrong, 1981). However, when adjusted by the pH, temperature, and ionic strength (Soderberg and Meade, 1991), the levels of unionized ammonia were within safe limits.

Treated mine waters also have much higher levels of sulfates. This is a factor of the amount of sulfur found in the coal mines from which the water is being pumped and treated. Again, the levels reported in this study were significantly higher than the recommended levels for rainbow trout, but according to Viadero and Tierney (2003) the fish were able to survive because of the effects of high ionic strength. Nevertheless, this is a constituent that should be closely monitored in mine water treatment facilities.

An evaluation of the issue of increased vulnerability of aquacultures utilizing mine waters was also conducted. This consisted of a modified Hazards and Operability (HAZOP) Analysis. A HAZOP analysis is a qualitative risk assessment of a chemical or mechanical process (Turton, 
1998). The purpose of this analysis was to identify as many possible upsets that could occur in the system, predict the possible impacts of such an upset, and suggest a corrective action to be taken if the upset occurs. It was first necessary to identify all components of the aquaculture system that were unique to operations utilizing treated mine waters, or conditions that were magnified by the presence of the MWTF upstream of the fish rearing facility. The components selected for analysis were the mine water pump, the hydrated lime injector, the mechanical aerator, the settling basin, and uncontrollable environmental factors, specifically storm events. Provided in Table 5.2 are the results of the HAZOP analysis of a typical aquaculture system supplied with water from a MWTF. For each of the potential upsets, an action to reduce the impact of the event is suggested. Two of these options are back-up water quality treatment systems, solids filtration and ionic exchange. These were selected for further discussion because of relevance to the upsets observed in this study. A design for these two systems is provided in Section 5.4. 
Table 5.2 HAZOP Risk Analysis on MWTF Aquaculture System

\begin{tabular}{|c|c|c|c|c|}
\hline System Component & Change & Results & Possible System Impacts & Action \\
\hline \multirow{6}{*}{ Mine Water Pump } & \multirow[b]{2}{*}{ Decreased pumping rate } & $\begin{array}{l}\text { Detention pond level decreased - reduced flow } \\
\text { rate and turn over }\end{array}$ & $\begin{array}{l}\text { Reduced DO; stress to fish; fish health threatened } \\
\text { (disease/mortality) }\end{array}$ & $\begin{array}{l}\text { Activate back-up aeration } \\
\text { system }\end{array}$ \\
\hline & & $\begin{array}{l}\text { Higher concentration of hydrated lime - } \mathrm{pH} \text { and } \\
\text { ammonia levels increase }\end{array}$ & $\begin{array}{l}\text { Too much alkalinity and toxic levels of unionized } \\
\text { ammonia - fish health threatened } \\
\text { (disease/mortality) }\end{array}$ & $\begin{array}{l}\text { Activate back-up pH } \\
\text { adjustment and ammonia } \\
\text { removal system }\end{array}$ \\
\hline & \multirow[b]{2}{*}{ Pumping stopped } & $\begin{array}{l}\text { Detention pond level decreased - reduced flow } \\
\text { rate and turn over }\end{array}$ & $\begin{array}{l}\text { Reduced DO; stress to fish; fish health threatened } \\
\text { (disease/mortality) }\end{array}$ & $\begin{array}{l}\text { Activate back-up aeration } \\
\text { system }\end{array}$ \\
\hline & & $\begin{array}{l}\text { Higher concentration of hydrated lime - } \mathrm{pH} \text { and } \\
\text { ammonia levels increase }\end{array}$ & $\begin{array}{l}\text { Too much alkalinity and toxic levels of unionized } \\
\text { ammonia - fish health threatened } \\
\text { (disease/mortality) }\end{array}$ & $\begin{array}{l}\text { Activate back-up pH } \\
\text { adjustment and ammonia } \\
\text { removal system }\end{array}$ \\
\hline & \multirow[b]{2}{*}{ Increased pumping rate } & $\begin{array}{l}\text { Detention pond level increased - water velocity } \\
\text { greater than particle settling velocity }\end{array}$ & $\begin{array}{l}\text { Increase turbidity, TSS, and total metals - fish } \\
\text { health threatened (disease/mortality) }\end{array}$ & $\begin{array}{l}\text { Activate back-up solids } \\
\text { filtration unit }\end{array}$ \\
\hline & & $\begin{array}{l}\text { Reduced concentration of hydrated lime - } \mathrm{pH} \\
\text { and ammonia levels decrease }\end{array}$ & $\begin{array}{l}\text { Low pH, insufficient precipitation; increased } \\
\text { turbidity and TSS - fish health threatened } \\
\text { (disease/mortality) }\end{array}$ & $\begin{array}{l}\text { Activate back-up pH } \\
\text { adjustment system }\end{array}$ \\
\hline \multirow{3}{*}{ Hydrated Lime Injector } & $\begin{array}{l}\text { Decreased rate of lime } \\
\text { addition }\end{array}$ & $\begin{array}{l}\text { Reduced concentration of hydrated lime - pH } \\
\text { and ammonia levels decrease }\end{array}$ & $\begin{array}{l}\text { Low pH, insufficient precipitation; increased } \\
\text { turbidity and TSS - fish health threatened } \\
\text { (disease/mortality) }\end{array}$ & $\begin{array}{l}\text { Activate back-up pH } \\
\text { adjustment system }\end{array}$ \\
\hline & Lime addition stopped & $\begin{array}{l}\text { Reduced concentration of hydrated lime - } \mathrm{pH} \\
\text { and ammonia levels decrease }\end{array}$ & $\begin{array}{l}\text { Low pH, insufficient precipitation; increased } \\
\text { turbidity and TSS - fish health threatened } \\
\text { (disease/mortality) }\end{array}$ & $\begin{array}{l}\text { Activate back-up pH } \\
\text { adjustment system }\end{array}$ \\
\hline & $\begin{array}{l}\text { Increased rate of lime } \\
\text { addition }\end{array}$ & $\begin{array}{l}\text { Higher concentration of hydrated lime - } \mathrm{pH} \text { and } \\
\text { ammonia levels increase }\end{array}$ & $\begin{array}{l}\text { Too much alkalinity and toxic levels of unionized } \\
\text { ammonia - fish health threatened } \\
\text { (disease/mortality) }\end{array}$ & $\begin{array}{l}\text { Activate back-up pH } \\
\text { adjustment and ammonia } \\
\text { removal system }\end{array}$ \\
\hline Mechanical Aerator & Aerator mechanical failure & $\begin{array}{l}\text { Insufficient aeration and lime mixing; } \mathrm{pH} \text { and } \\
\text { metal concentration hot zones }\end{array}$ & $\begin{array}{l}\text { DO reduced; insufficient precipitation - increased } \\
\text { turbidity and TSS; fish health threatened } \\
\text { (disease/mortality) }\end{array}$ & $\begin{array}{l}\text { Activate back-up aeration } \\
\text { system and solids filtration } \\
\text { unit }\end{array}$ \\
\hline Settling Basin & Filling from settled solids & $\begin{array}{l}\text { Reduced settling volume (reduced retention } \\
\text { time, increased turnover and flow velocity) }\end{array}$ & $\begin{array}{l}\text { Increase turbidity, TSS, and total metals - fish } \\
\text { health threatened (disease/mortality) }\end{array}$ & $\begin{array}{l}\text { Activate back-up solids } \\
\text { filtration unit }\end{array}$ \\
\hline \multirow{4}{*}{ Precipitation } & Less than average & $\begin{array}{l}\text { Detention pond level decreased - reduced flow } \\
\text { rate and turn over }\end{array}$ & $\begin{array}{l}\text { Reduced DO; stress to fish; fish health threatened } \\
\text { (disease/mortality) }\end{array}$ & $\begin{array}{l}\text { Activate back-up aeration } \\
\text { system }\end{array}$ \\
\hline & Greater than average & $\begin{array}{l}\text { Detention pond level increased - water velocity } \\
\text { greater than particle settling velocity }\end{array}$ & $\begin{array}{l}\text { Increase turbidity, TSS, and total metals - fish } \\
\text { health threatened (disease/mortality) }\end{array}$ & $\begin{array}{l}\text { Activate back-up solids } \\
\text { filtration unit }\end{array}$ \\
\hline & Storm event & $\begin{array}{l}\text { Detention pond level increased - water velocity } \\
\text { greater than particle settling velocity }\end{array}$ & $\begin{array}{l}\text { Increase turbidity, TSS, and total metals - fish } \\
\text { health threatened (disease/mortality) }\end{array}$ & $\begin{array}{l}\text { Activate back-up solids } \\
\text { filtration unit }\end{array}$ \\
\hline & Storm event & Increased run-off from surrounding water shed & $\begin{array}{l}\text { Increase turbidity, TSS, and total metals - fish } \\
\text { health threatened (disease/mortality) }\end{array}$ & $\begin{array}{l}\text { Activate back-up solids } \\
\text { filtration unit }\end{array}$ \\
\hline
\end{tabular}




\subsection{Back-up Treatment Options and Designs}

Three back-up treatment systems were selected for design and cost analysis from the HAZOP analysis. The first stage is a filtration system used to remove suspended solids. The second stage of treatment is the removal of dissolved metals with an ionic exchange unit. The third water treatment is a diffused aeration system to increase the level of dissolved oxygen.

\subsubsection{Solids Filtration Unit}

For the design of the suspended solids back-up filtration system, the average total flow rate and suspended solids concentrations from sampling during the disturbance event were used. The average flow rate was 675 gpm (2555 Lpm) and the TSS concentration was $10 \mathrm{mg} / \mathrm{L}$. Suspended solids in water can range from 0.001 to 100 micrometers in diameter. A diameter of $40 \mu \mathrm{m}$ was selected as the minimum size for removal because particles with smaller diameters will pass freely through the gills; therefore, they do not cause the irritation larger particles will.

Because of the quantity of water flow and the concentrations measured, a microscreen rotation drum filter was selected for treatment of the water influent. Microscreens are woven metallic or plastic filter fabric mounted on the frame of a rotating drum. Rotating drum filters are used frequently in water treatment for aquaculture systems, mostly for recirculating systems. These systems were selected because of the possibility of continuous operation, low maintenance, and minimum operator requirements. Rotating drum filters are self cleaning and require small quantities of rinse water. Solids removed are concentrated and collected in a sludge trough for disposal. Presented in Figure 5.9 is a diagram of a typical rotating drum filter manufactured by Hydrotech. The system design specifications and costs were provided by Water Management Technologies, Inc. (Beckman) and are summarized in Table 5.3. 


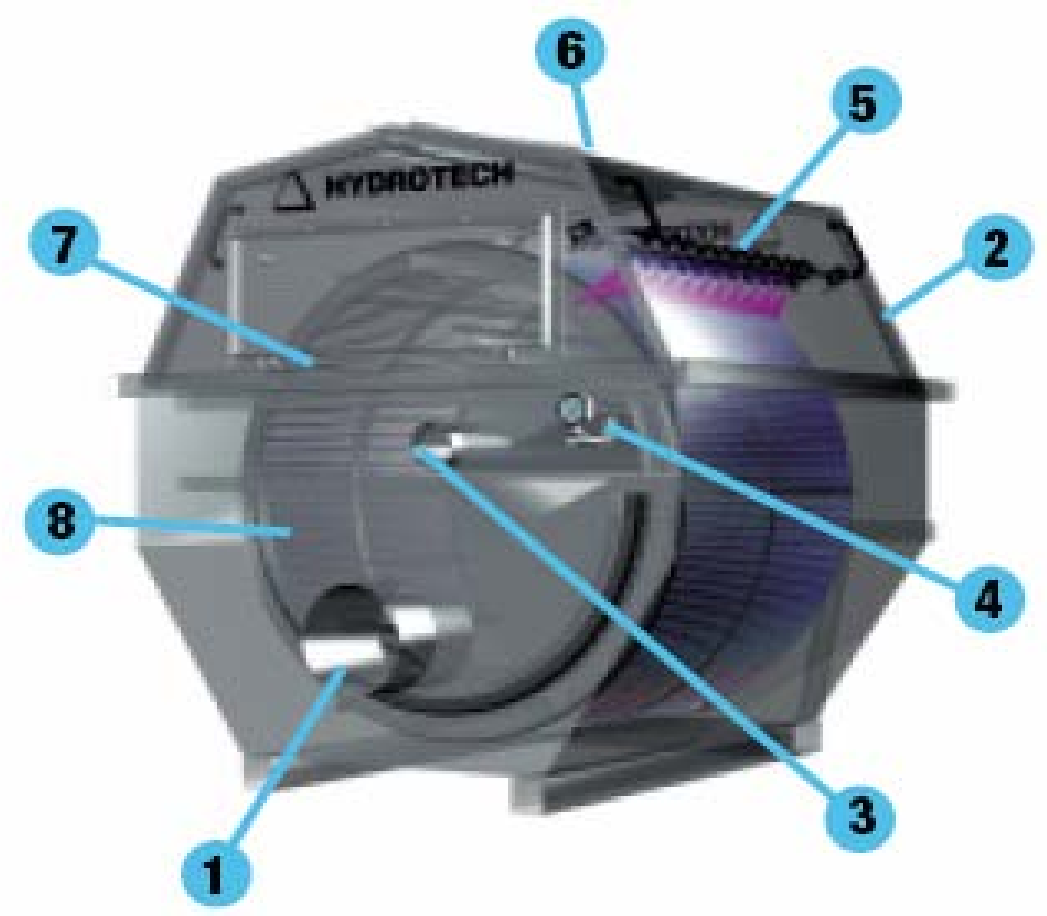

Figure 5.9 Diagram of Rotating Drum Microscreen Filtration System Design.

The labeled parts in Figure 5.9 are as follows:
1. Water inlet
2. Water outlet
3. Solids outlet
4. Rinse water connection
5. Back-wash header
6. Drive unit
7. Filter panels
8. Rubber lip sealing

Table 5.3 Microscreen Filtration System Design and Cost Summary.

\begin{tabular}{ccc}
\hline Design Parameter & Specification & Cost (\$) \\
\hline Rotating drum filter w/ vessel & 1H 803/304SS & 13,000 \\
Screen pore size, $\mu \mathrm{m}$ & 40 & -- \\
Surface area, ${ }^{2}$ & 2.88 & -- \\
Number Panels & 6 & -- \\
Drive Motor, kW & 0.25 & -- \\
Pressure drop, kPa & 2.94 & -- \\
High Pressure Rinse Pump, & 53.9 & 1000 \\
Lpm & 1.50 & -- \\
Backwash Motor, kW & -- & 1000 \\
Control System & & \\
\hline
\end{tabular}




\subsubsection{Ionic Exchange Unit}

The ionic exchange unit was scaled for a reduced flow rate due to anticipated high cost for treatment. The flow rate was adjusted so that the raceway segments would have the minimum three turnovers per hour for the density of fish present. The average measured concentrations of metals for the season were used and the design was based on the calculations for water conditions presented in Table 5.4.

Table 5.4 Summary of Water Conditions for Treatment in Ionic Exchange Column.

\begin{tabular}{cc}
\hline Water Conditions & Quantity \\
\hline Flow rate, Lpm & 1686 \\
Operation period, days & 1 \\
$\mathrm{Fe}^{3+}, \mathrm{mg} / \mathrm{L}$ & 0.16 \\
$\mathrm{Ca}^{3+}, \mathrm{mg} / \mathrm{L}$ & 363.0 \\
$\mathrm{Al}^{3+}, \mathrm{mg} / \mathrm{L}$ & 0.05 \\
$\mathrm{Mg}^{2+}, \mathrm{mg} / \mathrm{L}$ & 98.0 \\
$\mathrm{Mn}^{2+}, \mathrm{mg} / \mathrm{L}$ & 0.36 \\
Total equivalence & 85,622 \\
\hline
\end{tabular}

As a result of the costly nature of ionic exchange, the system was design for temporary operation for the scaled down flow rate. The concentrations used would not be reflective of a water quality upset, which would result in an even greater removal requirement on the system. Even with a short term reduced flow and concentrations at levels the fish have already performed well in, further treatment of the influent to the raceway system with ionic exchange proved to be cost prohibitive. This is presented in Table 5.5 with the design summary. 
Table 5.5 Summary of Ionic Exchange Treatment System and Cost Estimates

\begin{tabular}{ccc}
\hline Design Specifications & Size/Quantity & $\begin{array}{c}\text { Cost } \\
\mathbf{( \$ / 1 0 0 0 )}\end{array}$ \\
\hline Resin, kg & 16,396 & 172 \\
CEC, meq/100g & 470 & -- \\
Bulk density, kg/m ${ }^{3}$ & 1400 & -- \\
Volume of material, m & 11.71 & -- \\
Volume of vessel, ${ }^{3}$ & 50 & 75 \\
Pressure drop, $\mathrm{kPa}^{3}$ & 981 & -- \\
Regenerant volume $\left(\mathrm{H}_{2} \mathrm{SO}_{4}\right), \mathrm{m}^{3}$ & 100 & 8 \\
Regenerant concentration, v/v\% & 5 & - \\
\hline
\end{tabular}

The cationic exchange resin used in this design and cost estimation was Amberlyst ${ }^{\circledR}$ 15Wet. The vessel cost was estimated using CAPCOST (Turton, 1998) and does not include installation. From this information, it is clear that the use of ionic exchange is impractical for the present system.

\subsubsection{Aeration System}

For the design of an aeration system, the conditions selected were the average flow rate for the season, a starting concentration of $3 \mathrm{mg} / \mathrm{L}$, which is the minimum required for survival, and a final concentration of saturation, based on the highest temperature for survival. These were selected to provide a worst-case scenario. The saturation concentration was calculated using Equation 5.6 (Lin, 2001).

$$
D O_{\text {sat }}=14.652-0.41022 T+0.007991 T^{2}-0.000077774 T^{3}
$$

Equation 5.6

A blower supplying air through a perforated hose across the midpoint of each stage is suggested. A very conservative transfer efficiency of $2.0 \%$ was used, and the results are summarized in Table 5.6. 
Table 5.6 Summary of Aerator Design

\begin{tabular}{cc}
\hline Design Specifications & Quantity \\
\hline Flow rate, $\mathrm{Lpm}$ & 2555 \\
Temperature, ${ }^{\circ} \mathrm{C}$ & 25.0 \\
Initial Concentration, $\mathrm{mg} / \mathrm{L}$ & 3.00 \\
Saturation, $\mathrm{mg} / \mathrm{L}$ & 8.18 \\
Transfer efficiency, \% & 2.0 \\
Air compressor, $\mathrm{kPa}$ & 115 \\
Air flow rate, $\mathrm{Lpm}$ & 3705 \\
\hline
\end{tabular}

The cost summary for three possible systems is presented in Table 5.7 and was provided by Water Management Technologies, Inc. (Beckman).

Table 5.7 Summary of Aerator Costs

\begin{tabular}{rc}
\hline Design Specifications & Cost (\$) \\
\hline Single Blower & 4500 \\
$11.19 \mathrm{~kW}$ & -- \\
$16.3 \mathrm{~m}^{3} / \mathrm{min}$ & -- \\
$3.73 \mathrm{~kW}$ & 5100 \\
$13.9 \mathrm{~m}^{3} / \mathrm{min}$ & -- \\
Two Blowers (A) & -- \\
Two Blowers (B) & 6000 \\
$17.6 \mathrm{~m}^{3} / \mathrm{min}$ & -- \\
\hline
\end{tabular}




\section{CHAPTER 6. CONCLUSIONS AND RECOMMENDATIONS}

\subsection{Water Quality}

The water quality between the two sides of the raceway was not significantly different. The weekly field monitoring indicated no significant change over time for $\mathrm{pH}$, salinity, specific conductance, and flow rate. Dissolved oxygen decreased with increasing temperature and fish growth. With the exception of the disturbance event, turbidity also did not vary significantly. All these values were within the recommended levels for salmonids.

For the grab sample analysis, no significant difference between the two sides was observed. Nutrients and metals were within recommended levels after they were adjusted for $\mathrm{pH}$, temperature, or ionic strength. Sulfates were much greater than the recommended levels, but the fish did not appear to be impacted. Alkalinity and acidity also did not vary significantly with time.

\subsection{Feed Comparison}

Side A, the Ziegler diet, performed better than the VegiPro ${ }^{\circledR}$ diet fed to Side B. The differences in average growth rates and feed conversion ratios were statistically significant. The newly defined mortality adjusted feed conversion ratio also favored the Ziegler diet. The price per unit of mass gained were very close, with the VegiPro® diet being just over $\$ 0.01 / \mathrm{kg}$ mass gained more than Ziegler. Also, the Ziegler did produce a significant amount of waste more than the VegiPro®. The mass balances generated from the feed and waste data were statistically similar.

For future research, additional feed sources should continue to be studied. A more statistically designed experimental approach to feeding methods is also recommended; for example, more aggressive feed rates could be used during optimum growth periods. Also, more 
frequent analysis of feed density and content for QA/QC, as well as additional aqua-sludge characterization for content would provide a greater level of closure to the mass balances. Refining the aqua-sludge sampling method to minimize human error is also recommended. Finally, recording of mortality weight would make the mortality adjusted feed conversion ratio more exact.

\subsection{Disturbance Event}

The two water quality disturbance events resulted in the outbreak of the aeromonas infection, which caused a mortality rate of just over $20 \%$ for the system. The cause of the disturbance was attributed to upstream changes in the mine water treatment facility and heavy precipitation. These conclusions lead to the HAZOP risk assessment, which identified several potential vulnerabilities of the raceway system to similar events in the future. Although treated mine water has been utilized at an increasing level in aquaculture, it is important to identify possible system upsets and plan accordingly. Due to the reduced water quality during regular operation, the fish population may be in a compromised health condition, which would make them less able to recover from the stress of an upset, as well as the stress from typical intensive aquaculture operations (i.e. inventory sampling, moving, increased density).

\subsection{Back-up Treatment Units}

The response to the HAZOP analysis was to consider the design of three back-up treatment options. These systems could be utilized upon detection of a water quality upset during sampling events, or on-going field monitoring provided by YSI Sondes data. The three systems were a rotating drum micro-screen filtration unit for the removal of suspended solids, an ionic exchange column for removal of metals remaining after upstream treatment in the MWTF, 
and a diffused air aerator for increasing dissolved oxygen levels. The cost of the ionic exchange treatment unit proved to be too costly for the system currently being studied.

Further refining of the designs for the filtration system and the aerator are recommended to meet the specific requirements for future research efforts. The designs provided were based on the 2003-2004 season. Future research may require different levels of treatment if changes in water quality are anticipated or detected. Further, a different fish population or density would also alter the needs for these back-up treatment systems. Nevertheless, these two options are recommended for future installation. 


\section{CHAPTER 7. REFERENCES}

Beckman, Greg (2005) Water Management Technologies, Inc., Personal Communication.

Bender, T.R., Jr., W.B. Lukens, Jr. and D.C. Ricker. 1999. "Feed Conversion, Growth, and Deposition of Solid Waste When Production Rainbow Trout were Fed Three Commercially Available Salmonid Diets over a Five Month Period at the Benner Spring Fish Research Station.” Pennsylvania Fish and Boat Commission. Unpublished report.

Buttner, J.K., R.W. Soderberg, and D.E. Terlizzi. 1993. “An Introduction to Water Chemistry in Freshwater Aquaculture.” Fact Sheet Number 170.

Durborow, R.M. and R. Francis-Floyd. 1996. "Medicated Feed for Food Fish.” SRAC Publication No. 473.

Heinen, J.M. 1996. "Water Quality Criteria, Uptake, Bioaccumulation, and Public Health Considerations for Chemicals of Possible Concern in West Virginia Mine Waters Used for Culture of Rainbow Trout.” The Conservation Fund's Freshwater Institute, Shepherdstown, WV.

Hinshaw, J.M. and G. Fornshell (2002) "Effluents from Raceways," Aquaculture and the Environment in the United States, J.R. Tomasso, ed., U.S. Aquaculture Society, 77-104.

Hogg, R.V., and J. Ledolter. 1992. Applied Statistics for Engineers and Physical Scientists. Macmillan Publishing Company, New York, NY.

Klontz, G.W. A Manual for Trout and Salmon Production. Nelson \& Sons, Inc., South Murray, UT.

Lin, Shundra. 2001. Water and Wastewater Calculations Manual. McGraw-Hill, New York, NY.

Meade, J.W. 1989. Aquaculture Management. Van Nostrand Reinhold, New York.

Piper, R.G., I.B. McElwain, L.E. Orme, J.P. McCraren, L.G. Fowler and J.R. Leonard. 1982. "Fish Hatchery Management.” U.S. Fish and Wildlife Service, Washington, D.C.

Plumb, J.A. (1994) Health Maintenance of Cultured Fishes: Principal Microbial Diseases. CRC Press, Boca Raton.

Snoeyink, Vernon L. and D. Jenkins. 1980. Water Chemistry. John Wiley \& Sons, Inc, New York, NY.

Soderberg, Richard W. 1995. Flowing Water Fish Culture. Lewis Publishers, Boca Raton, Florida.

Soderberg, R.W. and J.W. Meade (1991) "The Effects of Ionic Strength on Un-ionized Ammonia Concentration,” Progressive Fish-Culturist, 53, 119. 
SPSS (1997). SigmaStat 2.0 User's Manual, ImageStream Graphics \& Presentation Filters, Chicago, IL.

Thompson, S. Forecast: Rainbow Trout Computer Forecasting Program. NC State University.

Turton, R., R.C. Bailie, W.B. Whiting and J.A. Shaeiwitz (1998) Analysis, Synthesis, and Design of Chemical Processes. Prentice Hall, PTR, Upper Saddle River, NJ.

Turton, R., R.C. Bailie, W.B. Whiting and J.A. Shaeiwitz (1998) CAPCOST@ Software. Prentice-Hall, Inc.

United States Environmental Protection Agency. 1973. “Water Quality Criteria,” EPA-R-73-033, U.S. Environmental Protection Agency, Washington, D.C. (“Blue Book”.)

United States Environmental Protection Agency. 1976. "Quality Criteria for Water.” U.S.

Environmental Protection Agency, Washington, D.C. (“Red Book”.)

United States Environmental Protection Agency. 1993. "Guidance for Assessing Chemical Containment Data for Use in Fish Advisories." Vol. I. Fish Sampling and Analysis. EPA 823-R93-002, U.S. Environmental Protection Agency, Washington, D.C.

United States Environmental Protection Agency. 1997. "Volunteer Stream Monitoring: A Methods Manual.” EPA 841-B-97-003, U.S. Environmental Protection Agency, Washington, D.C.

United States Environmental Protection Agency. 1999. "Volunteer Stream Monitoring: A Methods Manual.” EPA 841-B-97-003, U.S. Environmental Protection Agency, Washington, D.C.

Viadero, R.C., Jr., and A.E. Tierney. 2003. "Use of treated mine water for rainbow trout (Oncorhynchus mykiss) culture - a preliminary assessment.” Aquaculture Engineering 29:43-56.

Viadero, R.C., Jr., K.J. Semmens, and A.E. Tierney. 2004. "Use of treated mine water for rainbow trout (Oncorhynchus mykiss) culture - a production scale assessment.” Aquaculture Engineering 31(3-4):319-336.

Wedemeyer, Gary A., editor. 2001. Fish hatchery management, second edition. American Fisheries Society, Bethesda, Maryland. 


\section{APPENDIX A - OTHER WORKS CONSULTED}

Alabaster, J.S., and R. Lloyd. 1980. Water Quality Criteria for Freshwater Fish. Butterworths, London.

Allen, D.T and D.R. Shonnard. 2002. Green Engineering: Environmentally Conscious Design of Chemical Processes. Prentice Hall, Upper Saddle River, NJ.

Ashby, J.C., and J.M. Dean. “Treated Mine Drainage Effluent Benefits Maryland and West Virginia Fisherman,” Available: www.gcnet.net/mettiki/extra2.html.

Bell, M.C. 1986. Fisheries Handbook of Engineering and Biological Criteria. Fish Passage Development and Evaluation Program, U.S. Army Corps of Engineers, Portland,Oregon.

Brockson, R.W, M.D. Marcus, and H. Olem. 1992. Practical Guide to Managing Acidic Surface Waters and Their Fisheries. Lewis Publishers, Inc. Michigan.

Bureau, D.P., S.J. Gunther and C.Y. Cho. 2003. "Chemical Composition and Preliminary Theoretical Estimates of Waste Outputs of Rainbow Trout Reared in Commercial Cage Culture Operations in Ontario,” North American Journal of Aquaculture 65:33-38.

Buss, K. and E.R. Miller. 1971. “Considerations for Conventional Trout Hatchery Design and Construction in Pennsylvania.” Progressive Fish-Culturist 33:86-94.

Campbell, D. “Idaho Waste Management Guidelines for Aquaculture Operations.” State of Idaho, Division of Environmental Quality.

Camus, A.C., R.M. Dubrorow, W.G. Hemstreet, R.L. Thune and J.P. Hawke. 1998. "Aeromonas Bacterial Infections - Motile Aeromonad Septicemia.” SRAC Publication No. 478.

Cheremisinoff, P.N. and R.A. Young. 1976. Pollution Engineering Practice Handbook. Ann Arbor Science Publishers Inc. Ann Arbor, MI (399-404, 419-434).

Durborow, R.M., D.M. Crosby and M.W. Brunson. 1997. “Ammonia in Fish Ponds.” SRAC Publication No. 463.

Hargreaves, J.A. 1999. “Control of Clay Turbidity in Ponds.” SRAC Publication No. 460.

Haskell , D.C. 1959. Trout growth in hatcheries. New York Fish and Game Journal 6: 205-237.

Hayter, A.J. 1996. Probability and Statistics for Engineers and Scientists. PWS Publishing Co., Boston, MA.

Heath, A.G. 1987. Water Pollution and Fish Physiology. CRC Press, Inc., Boca Raton, Florida. 66 
Ladewig, Kathleen F., and M. Morat. January 1995. "Rainbow Trout,” Southern Regional Aquaculture Center Publication No. 224.

LaGrega, M.D., P.L. Buckingham and J.C. Evans. 2001. Hazardous Waste Management, $2^{\text {nd }}$ ed. McGraw Hill, Boston, MA (202-205).

Mier, M.V., R.L. Callejas, R. Gehr, B.E. Jimenez Cisneros and Pedro J.J. Alverez. 2001. "Heavy Metal Removal With Mexican Clinoptilolite: Multi-Component Ionic Exchange.” Water Resources 35(2):373-378.

Perry, R.H. and D.W. Green, 1997. Perry’s Chemical Engineer's Handbook, seventh edition. McGraw-Hill, New York, NY (16-1 - 16-66; 18-74 - 18-107) .

Playle, R.C., G.G. Gross, and C.M. Wood. 1989. Physiological Disturbances in Rainbow Trout (Salmo gairdneri) During Acid and Aluminum Exposures in Soft Water of Two Calcium Concentrations. Canadian Journal of Zoology 67:314-324.

Rottmann, R.W., R. Francis-Floyd and R. Durbrorow. 1992. “The Role of Stress in Fish Disease.” SRAC Publication No. 474.

Sprague, J.B. 1985. Factors that Modify Toxicity. Pages 124-163, in Rand, G.M., and S.R. Petrocelli (editors). Fundamentals of Aquatic Toxicology. Hemisphere Publishing Corp., Washington, D.C.

Swann, L. “A Fish Farmer's Guide to Understanding Water Quality,” http://aquanic.org/publicat/state/il-in/as-503.htm, 2001.

Weber, Walter J., Jr. 1972. Physicochemical Processes for Water Quality Control. John Wiley \& Sons, New York, NY. 


\section{APPENDIX B - DATA TABLES}

Table B.1. pH

\begin{tabular}{|c|c|c|c|c|c|c|c|c|c|}
\hline Date & HB & A1 & A2 & A3 & A4 & B1 & B2 & B3 & B4 \\
\hline $10 / 8 / 2003$ & 7.75 & 7.74 & 7.69 & 7.76 & 7.80 & 7.81 & 7.98 & 7.88 & 7.86 \\
\hline $10 / 13 / 2003$ & 7.89 & 7.87 & 7.99 & 7.97 & 8.08 & 7.92 & 8.02 & 8.04 & 8.08 \\
\hline $10 / 20 / 2003$ & 8.02 & 7.98 & 8.00 & 8.03 & 8.00 & 7.97 & 8.01 & 8.03 & 7.99 \\
\hline $10 / 27 / 2003$ & 8.30 & 8.26 & 8.27 & 8.28 & 8.31 & 8.28 & 8.27 & 8.29 & 8.33 \\
\hline $11 / 3 / 2003$ & 7.93 & 7.91 & 7.91 & 7.90 & 7.88 & 7.90 & 7.87 & 7.91 & 7.93 \\
\hline $11 / 10 / 2003$ & 8.01 & 7.98 & 7.99 & 8.00 & 8.01 & 7.99 & 7.98 & 7.99 & 8.02 \\
\hline $11 / 17 / 2003$ & 7.94 & 7.89 & 7.89 & 7.90 & 7.91 & 7.91 & 7.88 & 7.90 & 7.90 \\
\hline $11 / 24 / 2003$ & 8.13 & 8.09 & 8.08 & 8.08 & 8.10 & 8.08 & 8.07 & 8.06 & 8.08 \\
\hline $12 / 1 / 2003$ & 7.83 & 7.83 & 7.85 & 7.88 & 7.90 & 7.79 & 7.83 & 7.85 & 7.88 \\
\hline $12 / 8 / 2003$ & 7.94 & 7.92 & 7.92 & 7.93 & 7.96 & 7.93 & 7.91 & 7.92 & 7.93 \\
\hline $12 / 18 / 2003$ & 8.18 & 8.14 & 8.13 & 8.13 & 8.12 & 8.15 & 8.11 & 8.11 & 8.10 \\
\hline $12 / 22 / 2003$ & 8.10 & 8.06 & 8.07 & 8.10 & 8.11 & 8.07 & 8.09 & 8.09 & 8.10 \\
\hline $12 / 29 / 2003$ & 8.17 & 8.16 & 8.13 & 8.13 & 8.15 & 8.14 & 8.13 & 8.13 & 8.14 \\
\hline $1 / 13 / 2003$ & 8.16 & 8.11 & 8.12 & 8.12 & 8.12 & 8.11 & 8.11 & 8.11 & 8.11 \\
\hline $1 / 20 / 2004$ & 8.20 & 8.20 & 8.20 & 8.22 & 8.40 & 8.21 & 8.23 & 8.24 & 8.40 \\
\hline $1 / 28 / 2004$ & 7.94 & 7.20 & 7.94 & 7.96 & 7.98 & 7.90 & 7.91 & 7.93 & 7.93 \\
\hline $2 / 4 / 2004$ & 8.00 & 7.93 & 7.96 & 7.97 & 7.97 & 7.95 & 7.96 & 7.97 & 7.97 \\
\hline $2 / 11 / 2004$ & 8.00 & 7.99 & 7.99 & 8.01 & 8.00 & 8.00 & 8.01 & 8.01 & 8.03 \\
\hline $2 / 19 / 2004$ & 7.96 & 7.91 & 8.01 & 8.01 & 7.99 & 7.90 & 7.94 & 7.96 & 7.98 \\
\hline $2 / 25 / 2004$ & 7.89 & 7.90 & 7.94 & 7.96 & 7.99 & 7.88 & 7.92 & 7.94 & 7.98 \\
\hline $3 / 3 / 2004$ & 7.76 & 7.75 & 7.79 & 7.82 & 7.84 & 7.75 & 7.79 & 7.80 & 7.81 \\
\hline $3 / 10 / 2004$ & 7.75 & 7.73 & 7.74 & 7.76 & 7.80 & 7.76 & 7.78 & 7.80 & 7.80 \\
\hline 3/17/2004 & 7.96 & 7.93 & 7.91 & 7.92 & 7.93 & 7.94 & 7.92 & 7.95 & 7.95 \\
\hline $3 / 22 / 2004$ & 7.86 & 7.90 & 7.93 & 7.95 & 7.96 & 7.91 & 7.92 & 7.95 & 7.96 \\
\hline $4 / 1 / 2004$ & 7.90 & 7.81 & 7.75 & 7.75 & 7.75 & 7.81 & 7.78 & 7.78 & 7.75 \\
\hline $4 / 8 / 2004$ & 7.90 & 7.88 & 7.85 & 7.81 & 7.82 & 7.89 & 7.87 & 7.85 & 7.88 \\
\hline $4 / 14 / 2004$ & 7.75 & 7.67 & 7.68 & 7.69 & 7.70 & 7.69 & 7.69 & 7.69 & 7.71 \\
\hline $4 / 15 / 2004$ & 7.63 & 7.61 & 7.61 & 7.59 & 7.61 & 7.63 & 7.63 & 7.63 & 7.64 \\
\hline $4 / 22 / 2004$ & 7.66 & 7.56 & 7.51 & 7.44 & 7.43 & 7.63 & 7.56 & 7.57 & 7.51 \\
\hline $4 / 29 / 2004$ & 8.10 & 7.96 & 7.83 & 7.68 & 7.64 & 8.06 & 7.99 & 7.91 & 7.84 \\
\hline $5 / 7 / 2004$ & 8.20 & 8.05 & 7.89 & 7.63 & 7.54 & 8.10 & 7.95 & 7.94 & 7.77 \\
\hline $5 / 12 / 2004$ & 8.18 & 8.06 & 7.85 & 7.67 & 7.55 & 8.06 & 8.00 & 7.79 & 7.76 \\
\hline $5 / 19 / 2004$ & 8.24 & 8.11 & 7.90 & 7.79 & 7.67 & 8.09 & 8.01 & 7.86 & 7.79 \\
\hline $5 / 24 / 2004$ & 8.20 & 8.12 & 8.00 & 7.89 & 7.78 & 8.12 & 8.03 & 7.96 & 7.87 \\
\hline Mean & 7.98 & 7.92 & 7.92 & 7.90 & 7.91 & 7.95 & 7.95 & 7.94 & 7.93 \\
\hline Std. Dev & 0.1761 & 0.2090 & 0.1645 & 0.1875 & 0.2164 & 0.1598 & 0.1527 & 0.1541 & 0.1791 \\
\hline
\end{tabular}


Table B.2. Salinity (ppt)

\begin{tabular}{|c|c|c|c|c|c|c|c|c|c|}
\hline Date & HB & A1 & A2 & A3 & A4 & B1 & B2 & B3 & B4 \\
\hline $10 / 8 / 2003$ & 3.7 & 3.7 & 3.7 & 3.7 & 3.7 & 3.7 & 3.7 & 3.7 & 3.7 \\
\hline 10/13/2003 & 3.7 & 3.7 & 3.7 & 3.7 & 3.7 & 3.7 & 3.7 & 3.7 & 3.7 \\
\hline 10/20/2003 & 3.6 & 3.6 & 3.6 & 3.6 & 3.6 & 3.6 & 3.6 & 3.6 & 3.6 \\
\hline 10/27/2003 & 3.7 & 3.5 & 3.5 & 3.5 & 3.5 & 3.3 & 3.5 & 3.5 & 3.6 \\
\hline $11 / 3 / 2003$ & 3.6 & 3.7 & 3.6 & 3.7 & 3.6 & 3.6 & 3.6 & 3.6 & 3.6 \\
\hline $11 / 10 / 2003$ & 3.6 & 3.6 & 3.6 & 3.6 & 3.6 & 3.6 & 3.6 & 3.6 & 3.6 \\
\hline $11 / 17 / 2003$ & 3.4 & 3.5 & 3.4 & 3.4 & 3.4 & 3.5 & 3.4 & 3.4 & 3.4 \\
\hline $11 / 24 / 2003$ & 3.4 & 3.5 & 3.5 & 3.5 & 3.5 & 3.5 & 3.5 & 3.4 & 3.5 \\
\hline $12 / 1 / 2003$ & 3.4 & 3.4 & 3.4 & 3.4 & 3.4 & 3.4 & 3.4 & 3.4 & 3.4 \\
\hline $12 / 8 / 2003$ & 3.4 & 3.4 & 3.4 & 3.4 & 3.4 & 3.4 & 3.4 & 3.4 & 3.4 \\
\hline $12 / 18 / 2003$ & 3.3 & 3.3 & 3.3 & 3.3 & 3.3 & 3.3 & 3.3 & 3.3 & 3.3 \\
\hline $12 / 22 / 2003$ & 3.3 & 3.4 & 3.4 & 3.4 & 3.4 & 3.4 & 3.4 & 3.4 & 3.4 \\
\hline $12 / 29 / 2003$ & 3.2 & 3.2 & 3.3 & 3.3 & 3.3 & 3.2 & 3.3 & 3.3 & 3.3 \\
\hline $1 / 13 / 2003$ & 3.3 & 3.3 & 3.3 & 3.3 & 3.3 & 3.3 & 3.3 & 3.3 & 3.3 \\
\hline $1 / 20 / 2004$ & 3.4 & 3.4 & 3.4 & 3.4 & 3.3 & 3.4 & 3.4 & 3.4 & 3.4 \\
\hline $1 / 28 / 2004$ & 3.4 & 3.4 & 3.4 & 3.4 & 3.4 & 3.4 & 3.4 & 3.4 & 3.4 \\
\hline $2 / 4 / 2004$ & 3.2 & 3.3 & 3.3 & 3.3 & 3.3 & 3.3 & 3.3 & 3.3 & 3.3 \\
\hline $2 / 11 / 2004$ & 3.1 & 3.1 & 3.1 & 3.1 & 3.1 & 3.1 & 3.1 & 3.1 & 3.1 \\
\hline $2 / 19 / 2004$ & 3.2 & 3.2 & 3.3 & 3.2 & 3.2 & 3.1 & 3.1 & 3.2 & 3.2 \\
\hline $2 / 25 / 2004$ & 3.3 & 3.3 & 3.4 & 3.4 & 3.4 & 3.3 & 3.4 & 3.4 & 3.4 \\
\hline $3 / 3 / 2004$ & 3.4 & 3.4 & 3.4 & 3.4 & 3.4 & 3.3 & 3.4 & 3.4 & 3.4 \\
\hline $3 / 10 / 2004$ & 3.2 & 3.2 & 3.2 & 3.3 & 3.3 & 3.2 & 3.2 & 3.3 & 3.3 \\
\hline $3 / 17 / 2004$ & 3.3 & 3.3 & 3.3 & 3.3 & 3.3 & 3.3 & 3.3 & 3.3 & 3.3 \\
\hline $3 / 22 / 2004$ & 3.4 & 3.4 & 3.4 & 3.4 & 3.4 & 3.4 & 3.4 & 3.4 & 3.4 \\
\hline $4 / 1 / 2004$ & 3.3 & 3.4 & 3.4 & 3.4 & 3.4 & 3.4 & 3.4 & 3.4 & 3.4 \\
\hline $4 / 8 / 2004$ & 3.2 & 3.3 & 3.3 & 3.3 & 3.3 & 3.3 & 3.3 & 3.3 & 3.3 \\
\hline $4 / 14 / 2004$ & 3.4 & 3.4 & 3.4 & 3.4 & 3.4 & 3.4 & 3.4 & 3.4 & 3.3 \\
\hline $4 / 15 / 2004$ & 3.4 & 3.4 & 3.4 & 3.4 & 3.4 & 3.4 & 3.4 & 3.4 & 3.4 \\
\hline $4 / 22 / 2004$ & 3.3 & 3.3 & 3.3 & 3.3 & 3.3 & 3.3 & 3.3 & 3.3 & 3.3 \\
\hline $4 / 29 / 2004$ & 3.2 & 3.3 & 3.3 & 3.3 & 3.3 & 3.3 & 3.3 & 3.3 & 3.3 \\
\hline $5 / 7 / 2004$ & 3.4 & 3.4 & 3.4 & 3.4 & 3.4 & 3.4 & 3.4 & 3.4 & 3.4 \\
\hline $5 / 12 / 2004$ & 3.4 & 3.4 & 3.4 & 3.4 & 3.4 & 3.4 & 3.4 & 3.4 & 3.4 \\
\hline $5 / 19 / 2004$ & 3.5 & 3.5 & 3.5 & 3.5 & 3.5 & 3.5 & 3.5 & 3.5 & 3.5 \\
\hline $5 / 24 / 2004$ & 3.4 & 3.4 & 3.4 & 3.4 & 3.4 & 3.4 & 3.4 & 3.4 & 3.4 \\
\hline Mean & 3.4 & 3.4 & 3.4 & 3.4 & 3.4 & 3.4 & 3.4 & 3.4 & 3.4 \\
\hline Std. Dev & 0.1547 & 0.1435 & 0.1291 & 0.1347 & 0.1303 & 0.1438 & 0.1381 & 0.1279 & 0.1337 \\
\hline
\end{tabular}


Table B.3. Specific Conductance (mS/cm)

\begin{tabular}{|c|c|c|c|c|c|c|c|c|c|}
\hline Date & HB & A1 & A2 & A3 & A4 & B1 & B2 & B3 & B4 \\
\hline $10 / 8 / 2003$ & 6.67 & 6.67 & 6.67 & 6.67 & 6.66 & 6.66 & 6.67 & 6.67 & 6.66 \\
\hline $10 / 13 / 2003$ & 6.72 & 6.73 & 6.72 & 6.73 & 6.71 & 6.73 & 6.72 & 6.72 & 6.71 \\
\hline $10 / 20 / 2003$ & 6.59 & 6.62 & 6.61 & 6.60 & 6.59 & 6.61 & 6.61 & 6.60 & 6.61 \\
\hline $10 / 27 / 2003$ & 6.63 & 6.35 & 6.37 & 6.51 & 6.60 & 6.53 & 6.44 & 6.50 & 6.61 \\
\hline $11 / 3 / 2003$ & 6.60 & 6.63 & 6.63 & 6.62 & 6.61 & 6.62 & 6.62 & 6.62 & 6.62 \\
\hline $11 / 10 / 2003$ & 6.56 & 6.56 & 6.57 & 6.56 & 6.57 & 6.56 & 6.54 & 6.56 & 6.57 \\
\hline $11 / 17 / 2003$ & 6.29 & 6.31 & 6.29 & 6.28 & 6.26 & 6.32 & 6.31 & 6.28 & 6.27 \\
\hline $11 / 24 / 2003$ & 6.35 & 6.34 & 6.33 & 6.35 & 6.33 & 6.34 & 6.33 & 6.33 & 6.35 \\
\hline $12 / 1 / 2003$ & 6.25 & 6.28 & 6.27 & 6.27 & 6.29 & 6.28 & 6.26 & 6.29 & 6.27 \\
\hline $12 / 8 / 2003$ & 6.20 & 6.22 & 6.24 & 6.24 & 6.23 & 6.24 & 6.25 & 6.23 & 6.24 \\
\hline $12 / 18 / 2003$ & 6.14 & 6.13 & 6.13 & 6.11 & 6.12 & 6.13 & 6.13 & 6.15 & 6.12 \\
\hline $12 / 22 / 2003$ & 6.14 & 6.16 & 6.19 & 6.20 & 6.20 & 6.18 & 6.20 & 6.20 & 6.19 \\
\hline $12 / 29 / 2003$ & 5.83 & 5.94 & 6.05 & 6.10 & 6.11 & 5.92 & 6.08 & 6.12 & 6.10 \\
\hline $1 / 13 / 2003$ & 6.06 & 6.03 & 6.03 & 6.02 & 6.03 & 6.04 & 6.02 & 6.03 & 6.03 \\
\hline $1 / 20 / 2004$ & 6.18 & 6.19 & 6.19 & 6.20 & 6.15 & 6.20 & 6.19 & 6.20 & 6.19 \\
\hline $1 / 28 / 2004$ & 6.20 & 6.20 & 6.20 & 6.20 & 6.20 & 6.20 & 6.20 & 6.20 & 6.20 \\
\hline $2 / 4 / 2004$ & 6.00 & 6.00 & 6.00 & 6.00 & 6.00 & 6.00 & 6.00 & 6.00 & 6.00 \\
\hline $2 / 11 / 2004$ & 5.70 & 5.70 & 5.70 & 5.70 & 5.70 & 5.70 & 5.70 & 5.70 & 5.70 \\
\hline $2 / 19 / 2004$ & 5.94 & 5.96 & 5.98 & 5.96 & 5.96 & 5.70 & 5.71 & 5.95 & 5.95 \\
\hline $2 / 25 / 2004$ & 6.11 & 6.12 & 6.14 & 6.16 & 6.18 & 6.11 & 6.14 & 6.16 & 6.18 \\
\hline $3 / 3 / 2004$ & 6.27 & 6.24 & 6.23 & 6.25 & 6.27 & 6.25 & 6.24 & 6.27 & 6.28 \\
\hline $3 / 10 / 2004$ & 5.90 & 5.90 & 5.90 & 6.00 & 6.00 & 5.90 & 5.90 & 6.00 & 6.00 \\
\hline $3 / 17 / 2004$ & 6.06 & 6.08 & 6.09 & 6.08 & 6.07 & 6.07 & 6.09 & 6.08 & 6.07 \\
\hline $3 / 22 / 2004$ & 6.27 & 6.20 & 6.20 & 6.20 & 6.22 & 6.22 & 6.20 & 6.20 & 6.22 \\
\hline $4 / 1 / 2004$ & 6.12 & 6.14 & 6.18 & 6.19 & 6.21 & 6.14 & 6.19 & 6.20 & 6.22 \\
\hline $4 / 8 / 2004$ & 5.94 & 5.97 & 5.98 & 5.98 & 5.98 & 5.97 & 5.98 & 5.98 & 5.98 \\
\hline $4 / 14 / 2004$ & 6.25 & 6.26 & 6.25 & 6.20 & 6.13 & 6.26 & 6.26 & 6.23 & 6.13 \\
\hline $4 / 15 / 2004$ & 6.24 & 6.27 & 6.28 & 6.26 & 6.26 & 6.28 & 6.27 & 6.27 & 6.28 \\
\hline $4 / 22 / 2004$ & 6.06 & 6.08 & 6.10 & 6.11 & 6.10 & 6.08 & 6.10 & 6.09 & 6.10 \\
\hline $4 / 29 / 2004$ & 5.95 & 6.01 & 6.01 & 6.00 & 5.99 & 5.97 & 5.99 & 5.99 & 5.98 \\
\hline $5 / 7 / 2004$ & 6.15 & 6.19 & 6.19 & 6.20 & 6.21 & 6.19 & 6.19 & 6.20 & 6.21 \\
\hline $5 / 12 / 2004$ & 6.16 & 6.21 & 6.22 & 6.23 & 6.23 & 6.22 & 6.23 & 6.24 & 6.23 \\
\hline $5 / 19 / 2004$ & 6.32 & 6.32 & 6.35 & 6.34 & 6.34 & 6.34 & 6.33 & 6.34 & 6.34 \\
\hline $5 / 24 / 2004$ & 6.25 & 6.26 & 6.26 & 6.27 & 6.27 & 6.25 & 6.26 & 6.26 & 6.27 \\
\hline Mean & 6.21 & 6.21 & 6.22 & 6.23 & 6.23 & 6.21 & 6.22 & 6.23 & 6.23 \\
\hline Std. Dev & 0.2449 & 0.2299 & 0.2241 & 0.2236 & 0.2258 & 0.2484 & 0.2372 & 0.2223 & 0.2288 \\
\hline
\end{tabular}


Table B.4. Dissolved Oxygen (mg/L)

\begin{tabular}{|c|c|c|c|c|c|c|c|c|c|}
\hline Date & HB & A1 & A2 & A3 & A4 & B1 & B2 & B3 & B4 \\
\hline 10/8/2003 & 9.58 & 9.55 & 9.58 & 9.61 & 9.62 & 9.56 & 9.58 & 9.60 & 9.61 \\
\hline $10 / 13 / 2003$ & 9.00 & 8.96 & 8.91 & 8.90 & 8.44 & 8.95 & 8.93 & 8.92 & 8.31 \\
\hline $10 / 20 / 2003$ & 9.93 & 9.27 & 8.95 & 9.03 & 9.13 & 9.04 & 8.93 & 8.96 & 9.15 \\
\hline $10 / 27 / 2003$ & 10.09 & 9.34 & 9.18 & 9.14 & 9.43 & 9.48 & 9.27 & 9.19 & 9.40 \\
\hline $11 / 3 / 2003$ & 10.46 & 9.58 & 9.21 & 9.14 & 9.43 & 9.28 & 9.15 & 8.90 & 9.30 \\
\hline $11 / 10 / 2003$ & 10.22 & 9.48 & 9.30 & 9.17 & 9.35 & 9.01 & 9.30 & 9.17 & 9.06 \\
\hline $11 / 17 / 2003$ & 10.85 & 9.90 & 9.75 & 9.77 & 10.12 & 9.92 & 9.73 & 9.72 & 10.05 \\
\hline $11 / 24 / 2003$ & 11.44 & 10.70 & 10.20 & 10.13 & 10.33 & 10.49 & 10.07 & 10.14 & 10.22 \\
\hline $12 / 1 / 2003$ & 10.54 & 9.82 & 9.36 & 9.30 & 9.54 & 9.62 & 8.98 & 8.93 & 9.24 \\
\hline $12 / 8 / 2003$ & 12.80 & 11.43 & 11.61 & 11.43 & 11.76 & 11.58 & 11.09 & 11.25 & 11.61 \\
\hline $12 / 18 / 2003$ & 10.89 & 10.22 & 9.78 & 9.56 & 9.71 & 10.27 & 9.41 & 9.19 & 9.53 \\
\hline $12 / 22 / 2003$ & 11.10 & 10.45 & 10.20 & 10.13 & 10.23 & 10.25 & 10.18 & 10.12 & 10.20 \\
\hline $12 / 29 / 2003$ & 11.11 & 10.65 & 10.14 & 10.06 & 10.04 & 10.45 & 9.87 & 9.94 & 9.98 \\
\hline $1 / 13 / 2003$ & 11.06 & 10.22 & 9.99 & 9.80 & 9.83 & 10.25 & 9.85 & 9.79 & 9.80 \\
\hline $1 / 20 / 2004$ & 11.12 & 10.47 & 9.97 & 9.48 & 10.01 & 10.55 & 10.09 & 10.07 & 10.09 \\
\hline $1 / 28 / 2004$ & 10.72 & 10.10 & 9.85 & 9.95 & 10.03 & 9.96 & 9.76 & 9.99 & 10.02 \\
\hline $2 / 4 / 2004$ & 11.62 & 11.06 & 11.09 & 11.10 & 11.07 & 11.23 & 11.07 & 11.18 & 11.11 \\
\hline $2 / 11 / 2004$ & 11.31 & 10.60 & 10.39 & 10.36 & 10.39 & 10.72 & 10.37 & 10.46 & 10.35 \\
\hline $2 / 19 / 2004$ & 10.54 & 9.59 & 9.29 & 9.21 & 9.45 & 9.62 & 9.31 & 9.34 & 9.34 \\
\hline $2 / 25 / 2004$ & 9.53 & 8.64 & 8.52 & 8.42 & 8.62 & 8.80 & 8.48 & 8.50 & 8.57 \\
\hline $3 / 3 / 2004$ & 9.38 & 8.29 & 7.61 & 7.56 & 7.64 & 8.26 & 7.23 & 7.35 & 7.32 \\
\hline $3 / 10 / 2004$ & 8.98 & 7.86 & 7.43 & 7.47 & 7.55 & 7.96 & 7.35 & 7.53 & 7.60 \\
\hline $3 / 17 / 2004$ & 11.76 & 10.43 & 9.73 & 9.51 & 9.37 & 10.69 & 9.67 & 9.42 & 9.79 \\
\hline $3 / 22 / 2004$ & 10.98 & 10.18 & 9.77 & 9.55 & 9.24 & 10.18 & 9.82 & 9.63 & 9.08 \\
\hline $4 / 1 / 2004$ & 9.76 & 7.32 & 6.41 & 5.98 & 6.30 & 7.40 & 6.49 & 6.47 & 5.91 \\
\hline $4 / 8 / 2004$ & 10.70 & 9.81 & 9.06 & 9.13 & 9.08 & 9.97 & 9.85 & 9.62 & 9.58 \\
\hline $4 / 14 / 2004$ & 9.68 & 8.76 & 8.37 & 8.33 & 8.24 & 8.87 & 8.91 & 9.03 & 8.90 \\
\hline $4 / 15 / 2004$ & 9.76 & 8.79 & 9.56 & 9.44 & 8.12 & 9.12 & 9.12 & 9.08 & 8.76 \\
\hline $4 / 22 / 2004$ & 9.84 & 8.41 & 7.79 & 7.49 & 7.36 & 8.76 & 8.19 & 8.43 & 7.97 \\
\hline $4 / 29 / 2004$ & 10.79 & 8.96 & 8.11 & 7.51 & 7.33 & 9.74 & 9.36 & 9.15 & 8.74 \\
\hline $5 / 7 / 2004$ & 10.34 & 8.29 & 7.42 & 6.81 & 6.43 & 9.24 & 8.72 & 8.57 & 8.35 \\
\hline $5 / 12 / 2004$ & 9.95 & 7.78 & 6.50 & 6.06 & 5.99 & 8.64 & 7.94 & 8.02 & 7.79 \\
\hline $5 / 19 / 2004$ & 8.94 & 7.56 & 6.96 & 6.73 & 6.73 & 8.09 & 7.54 & 7.43 & 7.45 \\
\hline $5 / 24 / 2004$ & 8.28 & 7.16 & 6.61 & 6.30 & 6.34 & 7.50 & 7.14 & 6.98 & 7.00 \\
\hline Mean & 10.38 & 9.40 & 9.02 & 8.87 & 8.89 & 9.51 & 9.14 & 9.12 & 9.09 \\
\hline Std. Dev & 0.9438 & 1.1140 & 1.3012 & 1.3927 & 1.4598 & 1.0087 & 1.0850 & 1.0913 & 1.1959 \\
\hline
\end{tabular}


Table B.4. Dissolved Oxygen (\% Saturation)

\begin{tabular}{|c|c|c|c|c|c|c|c|c|c|}
\hline Date & HB & A1 & A2 & A3 & A4 & B1 & B2 & B3 & B4 \\
\hline $10 / 8 / 2003$ & 96.6 & 96.2 & 96.4 & 96.6 & 96.6 & 96.4 & 96.5 & 96.5 & 96.6 \\
\hline $10 / 13 / 2003$ & 93.5 & 93.1 & 92.6 & 92.4 & 87.7 & 93.9 & 92.8 & 92.6 & 86.3 \\
\hline $10 / 20 / 2003$ & 97.5 & 91.2 & 88.5 & 89.1 & 90.1 & 88.0 & 87.9 & 88.4 & 90.3 \\
\hline $10 / 27 / 2003$ & 97.5 & 89.8 & 88.4 & 88.0 & 90.8 & 91.4 & 89.4 & 88.7 & 90.5 \\
\hline $11 / 3 / 2003$ & 101.3 & 93.1 & 89.7 & 89.2 & 92.2 & 90.2 & 88.5 & 86.8 & 90.9 \\
\hline $11 / 10 / 2003$ & 95.0 & 88.1 & 86.4 & 85.1 & 86.6 & 83.7 & 86.4 & 84.7 & 83.7 \\
\hline $11 / 17 / 2003$ & 96.7 & 88.0 & 86.7 & 87.1 & 89.9 & 88.4 & 86.5 & 86.5 & 89.5 \\
\hline $11 / 24 / 2003$ & 104.6 & 97.6 & 93.8 & 92.4 & 94.2 & 95.7 & 91.7 & 92.4 & 93.2 \\
\hline $12 / 1 / 2003$ & 95.7 & 89.0 & 84.9 & 84.4 & 86.6 & 87.4 & 81.5 & 81.0 & 83.9 \\
\hline $12 / 8 / 2003$ & 113.6 & 105.5 & 102.6 & 100.9 & 103.8 & 102.4 & 98.0 & 99.4 & 102.4 \\
\hline $12 / 18 / 2003$ & 94.5 & 88.8 & 84.7 & 82.8 & 83.9 & 89.2 & 81.6 & 79.6 & 82.4 \\
\hline $12 / 22 / 2003$ & 95.4 & 89.7 & 87.6 & 87.3 & 88.0 & 87.9 & 87.5 & 87.0 & 87.5 \\
\hline $12 / 29 / 2003$ & 94.1 & 89.5 & 85.7 & 85.3 & 85.4 & 88.1 & 83.7 & 84.3 & 84.8 \\
\hline $1 / 13 / 2003$ & 92.9 & 86.0 & 84.0 & 82.3 & 82.4 & 86.2 & 82.8 & 82.2 & 82.2 \\
\hline $1 / 20 / 2004$ & 92.3 & 87.1 & 82.9 & 78.9 & 83.3 & 87.7 & 83.9 & 83.6 & 83.7 \\
\hline $1 / 28 / 2004$ & 87.3 & 82.2 & 80.0 & 80.6 & 81.1 & 81.2 & 79.2 & 80.8 & 80.9 \\
\hline $2 / 4 / 2004$ & 94.2 & 89.4 & 89.7 & 90.0 & 89.7 & 91.0 & 89.7 & 90.5 & 90.0 \\
\hline $2 / 11 / 2004$ & 93.0 & 87.0 & 85.2 & 85.1 & 85.6 & 87.9 & 85.2 & 85.9 & 85.1 \\
\hline 2/19/2004 & 91.1 & 82.8 & 80.2 & 79.5 & 81.5 & 83.0 & 80.4 & 80.6 & 80.5 \\
\hline $2 / 25 / 2004$ & 85.0 & 76.9 & 75.9 & 74.9 & 76.6 & 78.3 & 75.5 & 75.6 & 76.1 \\
\hline $3 / 3 / 2004$ & 85.6 & 75.5 & 69.3 & 69.2 & 69.9 & 75.6 & 66.0 & 67.2 & 66.7 \\
\hline $3 / 10 / 2004$ & 82.0 & 71.5 & 68.5 & 68.3 & 69.1 & 72.8 & 67.5 & 68.8 & 69.4 \\
\hline $3 / 17 / 2004$ & 106.0 & 94.0 & 87.5 & 85.6 & 84.2 & 95.5 & 87.1 & 89.2 & 87.9 \\
\hline $3 / 22 / 2004$ & 99.0 & 92.1 & 88.5 & 86.6 & 83.6 & 92.2 & 89.0 & 87.2 & 82.1 \\
\hline $4 / 1 / 2004$ & 94.8 & 71.3 & 62.2 & 58.1 & 61.1 & 71.7 & 63.0 & 62.7 & 57.4 \\
\hline $4 / 8 / 2004$ & 99.9 & 91.5 & 84.5 & 85.4 & 84.7 & 93.0 & 91.7 & 89.8 & 89.3 \\
\hline $4 / 14 / 2004$ & 91.1 & 83.2 & 79.4 & 79.0 & 78.1 & 84.2 & 84.6 & 85.6 & 84.5 \\
\hline $4 / 15 / 2004$ & 93.0 & 83.6 & 91.0 & 90.2 & 77.4 & 86.8 & 87.0 & 86.5 & 83.6 \\
\hline $4 / 22 / 2004$ & 95.1 & 80.9 & 75.0 & 72.3 & 70.9 & 84.3 & 79.1 & 81.1 & 76.8 \\
\hline $4 / 29 / 2004$ & 111.2 & 92.3 & 83.7 & 77.6 & 75.8 & 100.3 & 96.4 & 94.3 & 90.3 \\
\hline $5 / 7 / 2004$ & 110.5 & 88.4 & 79.0 & 72.5 & 68.5 & 98.5 & 93.0 & 91.5 & 89.2 \\
\hline $5 / 12 / 2004$ & 108.8 & 84.8 & 70.9 & 66.2 & 65.5 & 94.0 & 86.5 & 87.4 & 84.9 \\
\hline $5 / 19 / 2004$ & 101.8 & 86.1 & 79.4 & 76.7 & 76.5 & 92.2 & 85.8 & 84.5 & 84.9 \\
\hline $5 / 24 / 2004$ & 96.3 & 83.0 & 76.7 & 73.2 & 73.1 & 87.0 & 82.6 & 81.4 & 81.1 \\
\hline Mean & 96.7 & 87.3 & 83.6 & 82.1 & 82.2 & 88.4 & 84.9 & 84.8 & 84.4 \\
\hline Std. Dev & 7.3320 & 7.0433 & 8.3188 & 9.1299 & 9.3778 & 7.1262 & 8.0042 & 7.7567 & 8.3097 \\
\hline
\end{tabular}


Table B.5. Flow Rate, $\mathrm{H}_{\mathrm{w}}(\mathrm{cm})$

\begin{tabular}{|c|c|c|c|c|c|c|c|c|}
\hline Date & A1 & A2 & A3 & A4 & B1 & B2 & B3 & B4 \\
\hline $10 / 8 / 2003$ & 97.0 & 97.0 & 96.5 & 97.0 & 97.0 & 97.5 & 97.0 & 96.5 \\
\hline $10 / 13 / 2003$ & 96.5 & 97.0 & 96.5 & 96.0 & 96.5 & 97.5 & 97.0 & 97.0 \\
\hline $10 / 20 / 2003$ & 97.0 & 97.5 & 97.0 & 97.0 & 97.0 & 97.5 & 98.0 & 97.0 \\
\hline $10 / 27 / 2003$ & 97.5 & 97.5 & 97.5 & 97.0 & 97.0 & 98.0 & 98.0 & 97.0 \\
\hline $11 / 3 / 2003$ & 97.5 & 97.5 & 97.5 & 97.0 & 97.5 & 98.0 & 98.0 & 97.5 \\
\hline $11 / 10 / 2003$ & 98.0 & 98.0 & 98.0 & 97.0 & 97.0 & 98.0 & 98.0 & 98.0 \\
\hline $11 / 17 / 2003$ & 97.0 & 97.5 & 97.5 & 97.0 & 97.0 & 98.0 & 98.0 & 97.5 \\
\hline $11 / 24 / 2003$ & 98.0 & 98.0 & 98.0 & 97.5 & 98.0 & 98.0 & 98.0 & 98.0 \\
\hline $12 / 1 / 2003$ & 98.0 & 98.0 & 98.0 & 97.5 & 97.0 & 98.0 & 98.0 & 97.0 \\
\hline $12 / 8 / 2003$ & 98.0 & 98.0 & 98.0 & 97.5 & 97.5 & 98.0 & 98.0 & 97.5 \\
\hline $12 / 18 / 2003$ & 98.0 & 98.5 & 98.0 & 97.5 & 97.5 & 98.0 & 98.5 & 97.5 \\
\hline $12 / 22 / 2003$ & 98.0 & 98.0 & 98.0 & 98.0 & 97.5 & 98.0 & 98.0 & 98.0 \\
\hline $12 / 29 / 2003$ & 97.5 & 97.5 & 97.5 & 97.0 & 97.5 & 97.5 & 98.0 & 97.0 \\
\hline $1 / 20 / 2004$ & 98.0 & 97.0 & 98.0 & 97.0 & 97.0 & 98.0 & 98.0 & 97.0 \\
\hline $1 / 28 / 2004$ & 98.0 & 97.5 & 97.5 & 97.0 & 97.5 & 98.0 & 98.0 & 97.0 \\
\hline $2 / 4 / 2004$ & 97.5 & 98.0 & 98.0 & 97.5 & 97.5 & 98.0 & 98.0 & 97.5 \\
\hline $2 / 11 / 2004$ & 98.0 & 98.0 & 98.5 & 97.5 & 97.5 & 98.5 & 98.0 & 98.0 \\
\hline $2 / 19 / 2004$ & 98.0 & 98.0 & 98.0 & 97.0 & 98.0 & 98.0 & 98.0 & 97.0 \\
\hline $2 / 25 / 2004$ & 98.0 & 98.0 & 98.0 & 97.5 & 97.5 & 98.0 & 98.0 & 98.0 \\
\hline $3 / 3 / 2004$ & 98.0 & 98.0 & 98.0 & 97.5 & 97.5 & 98.0 & 98.0 & 97.5 \\
\hline $3 / 10 / 2004$ & 98.0 & 98.5 & 98.5 & 98.0 & 98.0 & 98.5 & 98.5 & 98.0 \\
\hline $3 / 17 / 2004$ & 98.5 & 99.0 & 99.0 & 98.5 & 98.5 & 99.0 & 99.0 & 98.5 \\
\hline $3 / 22 / 2004$ & 99.0 & 99.5 & 100.0 & 99.0 & 98.5 & 99.5 & 100.0 & 99.5 \\
\hline $4 / 1 / 2004$ & 98.0 & 98.0 & 97.5 & 98.5 & 98.5 & 98.5 & 98.5 & 98.0 \\
\hline $4 / 8 / 2004$ & 90.0 & 90.0 & 89.5 & 102.0 & 90.0 & 90.0 & 90.5 & 102.5 \\
\hline $4 / 14 / 2004$ & 89.0 & 89.0 & 89.0 & 101.0 & 90.0 & 90.0 & 90.0 & 100.5 \\
\hline $4 / 15 / 2004$ & 89.5 & 89.5 & 89.0 & 89.5 & 90.0 & 90.0 & 90.5 & 101.0 \\
\hline $4 / 22 / 2004$ & 89.5 & 89.5 & 89.0 & 101.5 & 90.0 & 90.5 & 91.0 & 94.5 \\
\hline $4 / 29 / 2004$ & 89.5 & 89.5 & 89.5 & 102.0 & 90.5 & 90.5 & 91.0 & 102.0 \\
\hline $5 / 7 / 2004$ & 89.5 & 89.5 & 89.5 & 102.0 & 91.0 & 91.0 & 91.5 & 102.5 \\
\hline $5 / 12 / 2004$ & 89.5 & 89.5 & 89.5 & 102.0 & 91.0 & 91.0 & 91.0 & 102.5 \\
\hline $5 / 19 / 2004$ & 89.5 & 89.5 & 89.5 & 102.0 & 90.0 & 90.0 & 90.5 & 101.0 \\
\hline $5 / 24 / 2004$ & 89.5 & 90.0 & 90.0 & 102.5 & 90.5 & 90.5 & 90.5 & 102.5 \\
\hline Mean & 95.5 & 95.6 & 95.6 & 98.3 & 95.5 & 96.0 & 96.1 & 98.5 \\
\hline Std. Dev & 3.7789 & 3.8079 & 3.8906 & 2.5560 & 3.2796 & 3.5078 & 3.3807 & 2.0879 \\
\hline \multicolumn{9}{|c|}{$\begin{array}{l}Q=1.83\left(L_{w}-0.1(2)(H)\right) * H^{3 / 2} \\
L_{w}=\text { Length of weir }=0.62 \mathrm{~m} \\
H=\text { Height of water above weir = Water level measured, Hw }- \text { Height of damboard, } H_{d} \\
H_{d}=0.9144 \mathrm{~m}(10 / 8 / 30-4 / 1 / 04) \text { for levels } 1-4 ; H_{d} \text { not recorded }(4 / 8 / 04-5 / 2404) \text { for levels 1-3 }\end{array}$} \\
\hline
\end{tabular}


Table B.5. Flow Rate, Q (Lpm)

\begin{tabular}{|c|c|c|c|c|c|c|c|c|}
\hline Date & A1 & A2 & A3 & A4 & B1 & B2 & B3 & B4 \\
\hline $10 / 8 / 2003$ & 876.5 & 876.5 & 762.2 & 876.5 & 876.5 & 995.7 & 876.5 & 762.2 \\
\hline $10 / 13 / 2003$ & 762.2 & 876.5 & 762.2 & 653.1 & 762.2 & 995.7 & 876.5 & 876.5 \\
\hline $10 / 20 / 2003$ & 876.5 & 995.7 & 876.5 & 876.5 & 876.5 & 995.7 & 1119.6 & 876.5 \\
\hline $10 / 27 / 2003$ & 995.7 & 995.7 & 995.7 & 876.5 & 876.5 & 1119.6 & 1119.6 & 876.5 \\
\hline $11 / 3 / 2003$ & 995.7 & 995.7 & 995.7 & 876.5 & 995.7 & 1119.6 & 1119.6 & 995.7 \\
\hline $11 / 10 / 2003$ & 1119.6 & 1119.6 & 1119.6 & 876.5 & 876.5 & 1119.6 & 1119.6 & 1119.6 \\
\hline $11 / 17 / 2003$ & 876.5 & 995.7 & 995.7 & 876.5 & 876.5 & 1119.6 & 1119.6 & 995.7 \\
\hline $11 / 24 / 2003$ & 1119.6 & 1119.6 & 1119.6 & 995.7 & 1119.6 & 1119.6 & 1119.6 & 1119.6 \\
\hline $12 / 1 / 2003$ & 1119.6 & 1119.6 & 1119.6 & 995.7 & 876.5 & 1119.6 & 1119.6 & 876.5 \\
\hline $12 / 8 / 2003$ & 1119.6 & 1119.6 & 1119.6 & 995.7 & 995.7 & 1119.6 & 1119.6 & 995.7 \\
\hline $12 / 18 / 2003$ & 1119.6 & 1247.9 & 1119.6 & 995.7 & 995.7 & 1119.6 & 1247.9 & 995.7 \\
\hline $12 / 22 / 2003$ & 1119.6 & 1119.6 & 1119.6 & 1119.6 & 995.7 & 1119.6 & 1119.6 & 1119.6 \\
\hline $12 / 29 / 2003$ & 995.7 & 995.7 & 995.7 & 876.5 & 995.7 & 995.7 & 1119.6 & 876.5 \\
\hline $1 / 20 / 2004$ & 1119.6 & 876.5 & 1119.6 & 876.5 & 876.5 & 1119.6 & 1119.6 & 876.5 \\
\hline $1 / 28 / 2004$ & 1119.6 & 995.7 & 995.7 & 876.5 & 995.7 & 1119.6 & 1119.6 & 876.5 \\
\hline $2 / 4 / 2004$ & 995.7 & 1119.6 & 1119.6 & 995.7 & 995.7 & 1119.6 & 1119.6 & 995.7 \\
\hline $2 / 11 / 2004$ & 1119.6 & 1119.6 & 1247.9 & 995.7 & 995.7 & 1247.9 & 1119.6 & 1119.6 \\
\hline $2 / 19 / 2004$ & 1119.6 & 1119.6 & 1119.6 & 876.5 & 1119.6 & 1119.6 & 1119.6 & 876.5 \\
\hline $2 / 25 / 2004$ & 1119.6 & 1119.6 & 1119.6 & 995.7 & 995.7 & 1119.6 & 1119.6 & 1119.6 \\
\hline $3 / 3 / 2004$ & 1119.6 & 1119.6 & 1119.6 & 995.7 & 995.7 & 1119.6 & 1119.6 & 995.7 \\
\hline $3 / 10 / 2004$ & 1119.6 & 1247.9 & 1247.9 & 1119.6 & 1119.6 & 1247.9 & 1247.9 & 1119.6 \\
\hline $3 / 17 / 2004$ & 1247.9 & 1380.6 & 1380.6 & 1247.9 & 1247.9 & 1380.6 & 1380.6 & 1247.9 \\
\hline $3 / 22 / 2004$ & 1380.6 & 1517.2 & 1657.8 & 1380.6 & 1247.9 & 1517.2 & 1657.8 & 1517.2 \\
\hline $4 / 1 / 2004$ & 1119.6 & 1119.6 & 995.7 & 1247.9 & 1247.9 & 1247.9 & 1247.9 & 1119.6 \\
\hline $4 / 8 / 2004$ & -- & -- & -- & 2256.5 & -- & -- & -- & 2414.6 \\
\hline $4 / 14 / 2004$ & -- & -- & -- & 1950.2 & -- & -- & -- & 1802.2 \\
\hline $4 / 15 / 2004$ & -- & -- & -- & 1950.2 & -- & -- & -- & 1950.2 \\
\hline $4 / 22 / 2004$ & -- & -- & -- & 2101.7 & -- & -- & -- & 1950.2 \\
\hline $4 / 29 / 2004$ & -- & -- & -- & 2256.5 & -- & -- & -- & 2256.5 \\
\hline $5 / 7 / 2004$ & -- & -- & -- & 2256.5 & -- & -- & -- & 2414.6 \\
\hline $5 / 12 / 2004$ & -- & -- & -- & 2256.5 & -- & -- & -- & 2414.6 \\
\hline $5 / 19 / 2004$ & -- & -- & -- & 2256.5 & -- & -- & -- & 1950.2 \\
\hline $5 / 24 / 2004$ & -- & -- & -- & 2414.6 & -- & -- & -- & 2414.6 \\
\hline Mean & 1069.9 & 1096.4 & 1092.7 & 1309.0 & 998.2 & 1142.4 & 1148.7 & 1330.9 \\
\hline Std. Dev & 130.5 & 149.7 & 184.2 & 568.2 & 130.3 & 118.8 & 148.2 & 557.1 \\
\hline Minimum & -- & -- & -- & 653.1 & -- & -- & -- & 762.2 \\
\hline Maximum & -- & -- & -- & 2414.6 & -- & -- & -- & 2414.6 \\
\hline
\end{tabular}


Table B.5. Flow Rate, Q (gpm)

\begin{tabular}{|c|c|c|c|c|c|c|c|c|}
\hline Date & A1 & A2 & A3 & A4 & B1 & B2 & B3 & B4 \\
\hline $10 / 8 / 2003$ & 231.5 & 231.5 & 201.4 & 231.5 & 231.5 & 263.0 & 231.5 & 201.4 \\
\hline 10/13/2003 & 201.4 & 231.5 & 201.4 & 172.5 & 201.4 & 263.0 & 231.5 & 231.5 \\
\hline $10 / 20 / 2003$ & 231.5 & 263.0 & 231.5 & 231.5 & 231.5 & 263.0 & 295.8 & 231.5 \\
\hline $10 / 27 / 2003$ & 263.0 & 263.0 & 263.0 & 231.5 & 231.5 & 295.8 & 295.8 & 231.5 \\
\hline $11 / 3 / 2003$ & 263.0 & 263.0 & 263.0 & 231.5 & 263.0 & 295.8 & 295.8 & 263.0 \\
\hline $11 / 10 / 2003$ & 295.8 & 295.8 & 295.8 & 231.5 & 231.5 & 295.8 & 295.8 & 295.8 \\
\hline $11 / 17 / 2003$ & 231.5 & 263.0 & 263.0 & 231.5 & 231.5 & 295.8 & 295.8 & 263.0 \\
\hline $11 / 24 / 2003$ & 295.8 & 295.8 & 295.8 & 263.0 & 295.8 & 295.8 & 295.8 & 295.8 \\
\hline $12 / 1 / 2003$ & 295.8 & 295.8 & 295.8 & 263.0 & 231.5 & 295.8 & 295.8 & 231.5 \\
\hline $12 / 8 / 2003$ & 295.8 & 295.8 & 295.8 & 263.0 & 263.0 & 295.8 & 295.8 & 263.0 \\
\hline $12 / 18 / 2003$ & 295.8 & 329.7 & 295.8 & 263.0 & 263.0 & 295.8 & 329.7 & 263.0 \\
\hline $12 / 22 / 2003$ & 295.8 & 295.8 & 295.8 & 295.8 & 263.0 & 295.8 & 295.8 & 295.8 \\
\hline $12 / 29 / 2003$ & 263.0 & 263.0 & 263.0 & 231.5 & 263.0 & 263.0 & 295.8 & 231.5 \\
\hline $1 / 20 / 2004$ & 295.8 & 231.5 & 295.8 & 231.5 & 231.5 & 295.8 & 295.8 & 231.5 \\
\hline $1 / 28 / 2004$ & 295.8 & 263.0 & 263.0 & 231.5 & 263.0 & 295.8 & 295.8 & 231.5 \\
\hline $2 / 4 / 2004$ & 263.0 & 295.8 & 295.8 & 263.0 & 263.0 & 295.8 & 295.8 & 263.0 \\
\hline $2 / 11 / 2004$ & 295.8 & 295.8 & 329.7 & 263.0 & 263.0 & 329.7 & 295.8 & 295.8 \\
\hline $2 / 19 / 2004$ & 295.8 & 295.8 & 295.8 & 231.5 & 295.8 & 295.8 & 295.8 & 231.5 \\
\hline $2 / 25 / 2004$ & 295.8 & 295.8 & 295.8 & 263.0 & 263.0 & 295.8 & 295.8 & 295.8 \\
\hline $3 / 3 / 2004$ & 295.8 & 295.8 & 295.8 & 263.0 & 263.0 & 295.8 & 295.8 & 263.0 \\
\hline $3 / 10 / 2004$ & 295.8 & 329.7 & 329.7 & 295.8 & 295.8 & 329.7 & 329.7 & 295.8 \\
\hline $3 / 17 / 2004$ & 329.7 & 364.7 & 364.7 & 329.7 & 329.7 & 364.7 & 364.7 & 329.7 \\
\hline $3 / 22 / 2004$ & 364.7 & 400.8 & 438.0 & 364.7 & 329.7 & 400.8 & 438.0 & 400.8 \\
\hline $4 / 1 / 2004$ & 295.8 & 295.8 & 263.0 & 329.7 & 329.7 & 329.7 & 329.7 & 295.8 \\
\hline $4 / 8 / 2004$ & -- & -- & -- & 596.1 & -- & -- & -- & 637.9 \\
\hline $4 / 14 / 2004$ & -- & -- & -- & 515.2 & -- & -- & -- & 476.1 \\
\hline $4 / 15 / 2004$ & -- & -- & -- & 515.2 & -- & -- & -- & 515.2 \\
\hline $4 / 22 / 2004$ & -- & -- & -- & 555.2 & -- & -- & -- & 515.2 \\
\hline $4 / 29 / 2004$ & -- & -- & -- & 596.1 & -- & -- & -- & 596.1 \\
\hline $5 / 7 / 2004$ & -- & -- & -- & 596.1 & -- & -- & -- & 637.9 \\
\hline $5 / 12 / 2004$ & -- & -- & -- & 596.1 & -- & -- & -- & 637.9 \\
\hline $5 / 19 / 2004$ & -- & -- & -- & 596.1 & -- & -- & -- & 515.2 \\
\hline $5 / 24 / 2004$ & -- & -- & -- & 637.9 & -- & -- & -- & 637.9 \\
\hline Mean & 282.6 & 289.6 & 288.7 & 345.8 & 263.7 & 301.8 & 303.4 & 351.6 \\
\hline Std. Dev & 34.5 & 39.6 & 48.7 & 150.1 & 34.4 & 31.4 & 39.1 & 147.2 \\
\hline Minimum & -- & -- & -- & 172.5 & -- & -- & -- & 201.4 \\
\hline Maximum & -- & -- & -- & 637.9 & -- & -- & -- & 637.9 \\
\hline
\end{tabular}


Table B.6. Temperature $\left({ }^{\circ} \mathrm{C}\right)$

\begin{tabular}{|c|c|c|c|c|c|c|c|c|c|}
\hline Date & HB & A1 & A2 & A3 & A4 & B1 & B2 & B3 & B4 \\
\hline $10 / 8 / 2003$ & 14.8 & 14.8 & 14.8 & 14.7 & 14.7 & 14.8 & 14.7 & 14.7 & 14.7 \\
\hline $10 / 13 / 2003$ & 16.1 & 16.0 & 16.0 & 15.9 & 15.8 & 16.0 & 16.0 & 15.9 & 15.9 \\
\hline $10 / 20 / 2003$ & 13.9 & 13.9 & 14.0 & 13.9 & 13.9 & 13.7 & 13.8 & 13.8 & 13.9 \\
\hline $10 / 27 / 2003$ & 13.0 & 13.4 & 13.3 & 13.3 & 13.3 & 13.3 & 13.3 & 13.3 & 13.3 \\
\hline $11 / 3 / 2003$ & 13.3 & 13.2 & 13.2 & 13.2 & 13.2 & 13.2 & 13.2 & 13.2 & 13.2 \\
\hline $11 / 10 / 2003$ & 11.2 & 11.1 & 11.0 & 10.9 & 10.8 & 11.1 & 11.1 & 10.9 & 10.8 \\
\hline $11 / 17 / 2003$ & 9.4 & 9.4 & 9.3 & 9.2 & 9.2 & 9.2 & 9.2 & 9.2 & 9.1 \\
\hline $11 / 24 / 2003$ & 10.5 & 10.3 & 10.3 & 10.2 & 10.3 & 10.4 & 10.3 & 10.2 & 10.2 \\
\hline $12 / 1 / 2003$ & 10.2 & 10.2 & 10.1 & 10.1 & 10.0 & 10.2 & 10.2 & 10.1 & 10.0 \\
\hline $12 / 8 / 2003$ & 9.3 & 9.1 & 9.0 & 8.9 & 8.9 & 9.1 & 8.9 & 8.9 & 8.8 \\
\hline $12 / 18 / 2003$ & 8.3 & 8.2 & 8.1 & 8.1 & 8.0 & 8.2 & 8.1 & 8.1 & 8.0 \\
\hline $12 / 22 / 2003$ & 8.0 & 7.8 & 7.8 & 7.8 & 7.8 & 7.7 & 7.8 & 7.8 & 7.8 \\
\hline $12 / 29 / 2003$ & 7.0 & 7.2 & 7.3 & 7.3 & 7.2 & 7.2 & 7.3 & 7.3 & 7.2 \\
\hline $1 / 13 / 2003$ & 6.7 & 6.7 & 6.7 & 6.7 & 6.7 & 6.7 & 6.7 & 6.7 & 6.7 \\
\hline $1 / 20 / 2004$ & 6.4 & 6.4 & 6.3 & 6.3 & 6.2 & 6.3 & 6.3 & 6.3 & 6.3 \\
\hline $1 / 28 / 2004$ & 5.6 & 5.6 & 5.4 & 5.5 & 5.5 & 5.6 & 5.6 & 5.5 & 5.5 \\
\hline $2 / 4 / 2004$ & 5.6 & 5.6 & 5.5 & 5.5 & 5.5 & 5.6 & 5.4 & 5.5 & 5.5 \\
\hline $2 / 11 / 2004$ & 6.1 & 6.2 & 6.1 & 6.1 & 6.0 & 6.0 & 6.0 & 6.1 & 6.0 \\
\hline $2 / 19 / 2004$ & 8.2 & 8.1 & 8.1 & 8.0 & 8.0 & 8.0 & 8.0 & 8.0 & 8.0 \\
\hline $2 / 25 / 2004$ & 9.3 & 9.3 & 9.2 & 9.2 & 9.1 & 9.4 & 9.3 & 9.2 & 9.1 \\
\hline $3 / 3 / 2004$ & 10.3 & 10.3 & 10.4 & 10.4 & 10.4 & 10.3 & 10.4 & 10.4 & 10.4 \\
\hline $3 / 10 / 2004$ & 10.6 & 10.5 & 10.4 & 10.5 & 10.5 & 10.3 & 10.4 & 10.5 & 10.5 \\
\hline $3 / 17 / 2004$ & 9.9 & 9.8 & 9.8 & 9.7 & 9.7 & 9.9 & 9.8 & 9.7 & 9.6 \\
\hline $3 / 22 / 2004$ & 10.1 & 10.1 & 10.0 & 10.0 & 9.9 & 10.1 & 10.1 & 10.0 & 9.9 \\
\hline $4 / 1 / 2004$ & 13.2 & 13.1 & 13.0 & 13.0 & 13.0 & 13.1 & 13.0 & 13.0 & 13.0 \\
\hline $4 / 8 / 2004$ & 11.5 & 11.4 & 11.3 & 11.3 & 11.3 & 11.4 & 11.3 & 11.3 & 11.3 \\
\hline $4 / 14 / 2004$ & 12.2 & 12.0 & 12.0 & 11.9 & 11.9 & 12.1 & 12.1 & 12.0 & 11.0 \\
\hline $4 / 15 / 2004$ & 12.4 & 12.4 & 12.4 & 12.3 & 12.4 & 12.3 & 12.3 & 12.3 & 12.3 \\
\hline $4 / 22 / 2004$ & 12.8 & 12.7 & 12.7 & 12.7 & 12.7 & 12.8 & 12.7 & 12.7 & 12.7 \\
\hline $4 / 29 / 2004$ & 15.5 & 15.6 & 15.7 & 15.9 & 16.1 & 16.0 & 16.0 & 15.9 & 16.0 \\
\hline $5 / 7 / 2004$ & 17.4 & 17.3 & 17.3 & 17.3 & 17.1 & 17.3 & 17.2 & 17.2 & 17.1 \\
\hline $5 / 12 / 2004$ & 19.0 & 19.0 & 18.9 & 18.8 & 18.8 & 18.8 & 18.8 & 18.7 & 18.7 \\
\hline $5 / 19 / 2004$ & 20.8 & 20.7 & 20.6 & 20.6 & 20.5 & 20.7 & 20.7 & 20.6 & 20.6 \\
\hline $5 / 24 / 2004$ & 21.7 & 21.7 & 21.7 & 21.7 & 21.7 & 21.7 & 21.7 & 21.7 & 21.7 \\
\hline Minimum & 5.6 & 5.6 & 5.4 & 5.5 & 5.5 & 5.6 & 5.4 & 5.5 & 5.5 \\
\hline Maximum & 21.7 & 21.7 & 21.7 & 21.7 & 21.7 & 21.7 & 21.7 & 21.7 & 21.7 \\
\hline
\end{tabular}


Table B.6. Temperature $\left({ }^{\circ} \mathrm{F}\right)$

\begin{tabular}{|c|c|c|c|c|c|c|c|c|c|}
\hline Date & HB & A1 & A2 & A3 & A4 & B1 & B2 & B3 & B4 \\
\hline $10 / 8 / 2003$ & 58.6 & 58.6 & 58.6 & 58.5 & 58.5 & 58.6 & 58.5 & 58.5 & 58.5 \\
\hline $10 / 13 / 2003$ & 61.0 & 60.8 & 60.8 & 60.6 & 60.4 & 60.8 & 60.8 & 60.6 & 60.6 \\
\hline $10 / 20 / 2003$ & 57.0 & 57.0 & 57.2 & 57.0 & 57.0 & 56.7 & 56.8 & 56.8 & 57.0 \\
\hline $10 / 27 / 2003$ & 55.4 & 56.1 & 55.9 & 55.9 & 55.9 & 55.9 & 55.9 & 55.9 & 55.9 \\
\hline $11 / 3 / 2003$ & 55.9 & 55.8 & 55.8 & 55.8 & 55.8 & 55.8 & 55.8 & 55.8 & 55.8 \\
\hline $11 / 10 / 2003$ & 52.2 & 52.0 & 51.8 & 51.6 & 51.4 & 52.0 & 52.0 & 51.6 & 51.4 \\
\hline $11 / 17 / 2003$ & 48.9 & 48.9 & 48.7 & 48.6 & 48.6 & 48.6 & 48.6 & 48.6 & 48.4 \\
\hline $11 / 24 / 2003$ & 50.9 & 50.5 & 50.5 & 50.4 & 50.5 & 50.7 & 50.5 & 50.4 & 50.4 \\
\hline $12 / 1 / 2003$ & 50.4 & 50.4 & 50.2 & 50.2 & 50.0 & 50.4 & 50.4 & 50.2 & 50.0 \\
\hline $12 / 8 / 2003$ & 48.7 & 48.4 & 48.2 & 48.0 & 48.0 & 48.4 & 48.0 & 48.0 & 47.8 \\
\hline $12 / 18 / 2003$ & 46.9 & 46.8 & 46.6 & 46.6 & 46.4 & 46.8 & 46.6 & 46.6 & 46.4 \\
\hline $12 / 22 / 2003$ & 46.4 & 46.0 & 46.0 & 46.0 & 46.0 & 45.9 & 46.0 & 46.0 & 46.0 \\
\hline $12 / 29 / 2003$ & 44.6 & 45.0 & 45.1 & 45.1 & 45.0 & 45.0 & 45.1 & 45.1 & 45.0 \\
\hline $1 / 13 / 2003$ & 44.1 & 44.1 & 44.1 & 44.1 & 44.1 & 44.1 & 44.1 & 44.1 & 44.1 \\
\hline $1 / 20 / 2004$ & 43.5 & 43.5 & 43.3 & 43.3 & 43.2 & 43.3 & 43.3 & 43.3 & 43.3 \\
\hline $1 / 28 / 2004$ & 42.1 & 42.1 & 41.7 & 41.9 & 41.9 & 42.1 & 42.1 & 41.9 & 41.9 \\
\hline $2 / 4 / 2004$ & 42.1 & 42.1 & 41.9 & 41.9 & 41.9 & 42.1 & 41.7 & 41.9 & 41.9 \\
\hline $2 / 11 / 2004$ & 43.0 & 43.2 & 43.0 & 43.0 & 42.8 & 42.8 & 42.8 & 43.0 & 42.8 \\
\hline $2 / 19 / 2004$ & 46.8 & 46.6 & 46.6 & 46.4 & 46.4 & 46.4 & 46.4 & 46.4 & 46.4 \\
\hline $2 / 25 / 2004$ & 48.7 & 48.7 & 48.6 & 48.6 & 48.4 & 48.9 & 48.7 & 48.6 & 48.4 \\
\hline $3 / 3 / 2004$ & 50.5 & 50.5 & 50.7 & 50.7 & 50.7 & 50.5 & 50.7 & 50.7 & 50.7 \\
\hline $3 / 10 / 2004$ & 51.1 & 50.9 & 50.7 & 50.9 & 50.9 & 50.5 & 50.7 & 50.9 & 50.9 \\
\hline $3 / 17 / 2004$ & 49.8 & 49.6 & 49.6 & 49.5 & 49.5 & 49.8 & 49.6 & 49.5 & 49.3 \\
\hline $3 / 22 / 2004$ & 50.2 & 50.2 & 50.0 & 50.0 & 49.8 & 50.2 & 50.2 & 50.0 & 49.8 \\
\hline $4 / 1 / 2004$ & 55.8 & 55.6 & 55.4 & 55.4 & 55.4 & 55.6 & 55.4 & 55.4 & 55.4 \\
\hline $4 / 8 / 2004$ & 52.7 & 52.5 & 52.3 & 52.3 & 52.3 & 52.5 & 52.3 & 52.3 & 52.3 \\
\hline $4 / 14 / 2004$ & 54.0 & 53.6 & 53.6 & 53.4 & 53.4 & 53.8 & 53.8 & 53.6 & 51.8 \\
\hline $4 / 15 / 2004$ & 54.3 & 54.3 & 54.3 & 54.1 & 54.3 & 54.1 & 54.1 & 54.1 & 54.1 \\
\hline $4 / 22 / 2004$ & 55.0 & 54.9 & 54.9 & 54.9 & 54.9 & 55.0 & 54.9 & 54.9 & 54.9 \\
\hline $4 / 29 / 2004$ & 59.9 & 60.1 & 60.3 & 60.6 & 61.0 & 60.8 & 60.8 & 60.6 & 60.8 \\
\hline $5 / 7 / 2004$ & 63.3 & 63.1 & 63.1 & 63.1 & 62.8 & 63.1 & 63.0 & 63.0 & 62.8 \\
\hline $5 / 12 / 2004$ & 66.2 & 66.2 & 66.0 & 65.8 & 65.8 & 65.8 & 65.8 & 65.7 & 65.7 \\
\hline $5 / 19 / 2004$ & 69.4 & 69.3 & 69.1 & 69.1 & 68.9 & 69.3 & 69.3 & 69.1 & 69.1 \\
\hline $5 / 24 / 2004$ & 71.1 & 71.1 & 71.1 & 71.1 & 71.1 & 71.1 & 71.1 & 71.1 & 71.1 \\
\hline Minimum & 42.1 & 42.1 & 41.7 & 41.9 & 41.9 & 42.1 & 41.7 & 41.9 & 41.9 \\
\hline Maximum & 71.1 & 71.1 & 71.1 & 71.1 & 71.1 & 71.1 & 71.1 & 71.1 & 71.1 \\
\hline
\end{tabular}


Table B.7. Turbidity (NTU)

\begin{tabular}{|c|c|c|c|c|c|c|c|c|c|}
\hline Date & HB & A1 & A2 & A3 & A4 & B1 & B2 & B3 & B4 \\
\hline $10 / 8 / 2003$ & 3.74 & 4.02 & 3.8 & 3.7 & 3.82 & 3.98 & 3.99 & 4.15 & 3.88 \\
\hline $10 / 13 / 2003$ & 3.49 & 4.16 & 4 & 3.86 & 4.25 & 4.06 & 4.11 & 3.54 & 3.71 \\
\hline $10 / 20 / 2003$ & 3.17 & 3.54 & 3.72 & 3.31 & 3.37 & 3.61 & 3.73 & 3.82 & 4.08 \\
\hline $10 / 27 / 2003$ & 3.35 & 3.35 & 3.35 & 3.78 & 3.34 & 3.35 & 3.35 & 3.61 & 3.36 \\
\hline $11 / 3 / 2003$ & 3.21 & 3.21 & 3.21 & 3.16 & 3.52 & 3.59 & 3.39 & 3.52 & 2.86 \\
\hline $11 / 10 / 2003$ & 3.36 & 3.44 & 3.48 & 3.56 & 3.62 & 3.41 & 3.4 & 3.47 & 3.58 \\
\hline $11 / 17 / 2003$ & 3.92 & 3.3 & 4.17 & 4.28 & 4.7 & 4.01 & 4.03 & 3.95 & 4.34 \\
\hline $11 / 24 / 2003$ & 4.63 & 4.73 & 4.46 & 5.03 & 4.8 & 4.33 & 4.45 & 5.33 & 4.55 \\
\hline $12 / 1 / 2003$ & 3.98 & 3.81 & 3.64 & 3.6 & 3.35 & 3.95 & 4.21 & 3.55 & 3.47 \\
\hline $12 / 8 / 2003$ & 2.73 & 2.58 & 2.7 & 2.82 & 2.78 & 3.06 & 2.69 & 2.38 & 2.89 \\
\hline $12 / 18 / 2003$ & 1.89 & 2.07 & 2.15 & 2.57 & 2.93 & 2 & 1.67 & 2.26 & 2.68 \\
\hline $12 / 22 / 2003$ & 2.69 & 2.74 & 2.32 & 2.71 & 2.83 & 2.56 & 2.68 & 2.72 & 3.07 \\
\hline $12 / 29 / 2003$ & 3.24 & 3.26 & 3.28 & 3.27 & 3.29 & 3.33 & 3.15 & 3.29 & 3.59 \\
\hline $1 / 13 / 2003$ & 3.88 & 3.78 & 3.77 & 3.87 & 4.08 & 3.78 & 3.98 & 4.32 & 4.19 \\
\hline $1 / 20 / 2004$ & 4.5 & 4.72 & 4.62 & 4.93 & 4.22 & 4.22 & 4.28 & 4.41 & 4.84 \\
\hline $1 / 28 / 2004$ & 4.06 & 3.6 & 3.34 & 3.92 & 4.5 & 3.57 & 4.07 & 3.87 & 4.01 \\
\hline $2 / 4 / 2004$ & 4.78 & 4.78 & 4.62 & 4.48 & 4.86 & 4.69 & 4.73 & 4.73 & 4.7 \\
\hline $2 / 11 / 2004$ & 5.46 & 5.45 & 5.06 & 5.32 & 5.41 & 5.75 & 5.62 & 5.5 & 5.44 \\
\hline $2 / 19 / 2004$ & 3.85 & 3.43 & 3.89 & 3.94 & 4.21 & 4.11 & 4.06 & 3.5 & 4.16 \\
\hline $2 / 25 / 2004$ & 3.33 & 3.46 & 4.53 & 3.87 & 3.46 & 3.28 & 2.98 & 3.32 & 3.83 \\
\hline $3 / 3 / 2004$ & 3.04 & 2.85 & 3.09 & 3.17 & 3.27 & 3.04 & 2.86 & 3.02 & 3.02 \\
\hline $3 / 10 / 2004$ & 21.7 & 22.7 & 29.2 & 28.3 & 28.9 & 23.5 & 30.2 & 29.5 & 29.4 \\
\hline $3 / 17 / 2004$ & 6.56 & 6.84 & 6.73 & 8.06 & 6.86 & 6.39 & 6.61 & 6.95 & 6.88 \\
\hline $3 / 22 / 2004$ & 4.14 & 3.6 & 4.21 & 4.72 & 4.33 & 4.24 & 4.27 & 5.55 & 7.55 \\
\hline $4 / 1 / 2004$ & 7.03 & 7.48 & 7.38 & 8.08 & 8.67 & 7.35 & 7.98 & 8.61 & 8.81 \\
\hline $4 / 8 / 2004$ & 11.8 & 11.9 & 12.4 & 12.3 & 12.4 & 11.5 & 12.1 & 12.1 & 12.4 \\
\hline $4 / 14 / 2004$ & 46.7 & 45.5 & 43.2 & 44.5 & 48.1 & 46 & 46 & 44.1 & 44.4 \\
\hline $4 / 15 / 2004$ & 40.3 & 40.8 & 42.9 & 41.7 & 42.9 & 40.3 & 40.3 & 43 & 42 \\
\hline $4 / 22 / 2004$ & 23.5 & 22.2 & 21.8 & 23.8 & 24 & 23.3 & 24 & 22.6 & 22.8 \\
\hline $4 / 29 / 2004$ & 8.1 & 7.44 & 7.88 & 8.98 & 8.11 & 8.19 & 8.59 & 8.17 & 8.72 \\
\hline $5 / 7 / 2004$ & 6.33 & 7.42 & 7.99 & 8.07 & 5.96 & 5.89 & 5.87 & 5.94 & 6.94 \\
\hline $5 / 12 / 2004$ & 5.28 & 4.76 & 5.39 & 5.15 & 5.34 & 5.75 & 5.64 & 6.95 & 6.34 \\
\hline $5 / 19 / 2004$ & 3.77 & 4.14 & 3.92 & 3.55 & 4.02 & 4.16 & 4.6 & 4.03 & \\
\hline $5 / 24 / 2004$ & 4.1 & 3.92 & 4.19 & 4.05 & 4.76 & 4.19 & 4.05 & 4.28 & 4.85 \\
\hline \multicolumn{10}{|c|}{ Excluding Disturbance Data } \\
\hline Mean & 4.45 & 4.46 & 4.58 & 4.74 & 4.70 & 4.51 & 4.57 & 4.69 & 4.92 \\
\hline Std. Dev & 1.9491 & 2.0040 & 2.0863 & 2.2064 & 2.0362 & 1.8895 & 2.0581 & 2.1080 & 2.2206 \\
\hline
\end{tabular}


Table B.8. Grab Sample Results - In House

\begin{tabular}{|c|c|c|c|c|c|}
\hline Head Box & Alkalinity & Acidity & Sulfates & TSS & BOD $_{\mathbf{5}}$ \\
\hline Date & $\mathrm{mg} / \mathrm{L} \mathrm{CaCO}_{3}$ & $\mathrm{mg} / \mathrm{L} \mathrm{CaCO}_{3}$ & $\mathrm{mg} / \mathrm{L}$ & $\mathrm{mg} / \mathrm{L}$ & $\mathrm{mg} / \mathrm{L}$ \\
\hline $10 / 8 / 2003$ & 358 & 11 & 3280 & 3.5 & 0.64 \\
\hline $11 / 17 / 2003$ & 348 & 12 & 3040 & 7 & 1.17 \\
\hline $12 / 18 / 2003$ & 347 & 16 & 3310 & 3 & 1.42 \\
\hline $1 / 20 / 2004$ & 355 & 9 & 2350 & 5 & 0.71 \\
\hline $2 / 20 / 2004$ & 397 & 12 & -- & 7 & 0.89 \\
\hline $3 / 22 / 2004$ & 420 & 18 & 3050 & 2.5 & 1.15 \\
\hline $4 / 23 / 2004$ & 309 & 14 & 2957 & 4 & 0.76 \\
\hline $5 / 24 / 2004$ & 127 & 1 & 3660 & 2 & -- \\
\hline Mean & 333 & 12 & 3092 & 4 & 0.96 \\
\hline Std. Dev. & 90 & 5 & 404 & 2 & 0.29 \\
\hline
\end{tabular}

\begin{tabular}{|c|c|c|c|c|c|}
\hline A4 & Alkalinity & Acidity & Sulfates & TSS & BOD \\
\hline Date & $\mathrm{mg} / \mathrm{L} \mathrm{CaCO}_{3}$ & $\mathrm{mg} / \mathrm{L} \mathrm{CaCO}_{3}$ & $\mathrm{mg} / \mathrm{L}$ & $\mathrm{mg} / \mathrm{L}$ & $\mathrm{mg} / \mathrm{L}$ \\
\hline $10 / 8 / 2003$ & 362 & 6 & 3300 & 7 & 0.78 \\
\hline $11 / 17 / 2003$ & 346 & 12 & 3290 & 6 & 1.61 \\
\hline $12 / 18 / 2003$ & 348 & 15 & 3260 & 4 & 6.36 \\
\hline $1 / 20 / 2004$ & 356 & 15 & 3150 & 1.5 & 4.43 \\
\hline $2 / 20 / 2004$ & 403 & 11 & -- & 6.5 & 1.86 \\
\hline $3 / 22 / 2004$ & 419 & 17 & 3170 & 3 & 1.75 \\
\hline $4 / 23 / 2004$ & 320 & 18 & 2990 & 8 & 4.91 \\
\hline $5 / 24 / 2004$ & 140 & 7 & 3020 & 11 & -- \\
\hline Mean & 337 & 13 & 3169 & 6 & 3.10 \\
\hline Std. Dev. & 86 & 4 & 126 & 3 & 2.11 \\
\hline
\end{tabular}

\begin{tabular}{|c|c|c|c|c|c|}
\hline B4 & Alkalinity & Acidity & Sulfates & TSS & BOD \\
\hline Date & $\mathrm{mg} / \mathrm{L} \mathrm{CaCO}_{3}$ & $\mathrm{mg} / \mathrm{L} \mathrm{CaCO}_{3}$ & $\mathrm{mg} / \mathrm{L}$ & $\mathrm{mg} / \mathrm{L}$ & $\mathrm{mg} / \mathrm{L}$ \\
\hline $10 / 8 / 2003$ & 359 & 5 & 3260 & 5 & 1.03 \\
\hline $11 / 17 / 2003$ & 349 & 12 & 3230 & 8 & 1.66 \\
\hline $12 / 18 / 2003$ & 350 & 15 & 2980 & 3 & 3.38 \\
\hline $1 / 20 / 2004$ & 356 & 11 & 2440 & 5 & 2.07 \\
\hline $2 / 20 / 2004$ & 395 & 12 & -- & 5 & 2.2 \\
\hline $3 / 22 / 2004$ & 415 & 17 & 2797 & 6 & 1.4 \\
\hline $4 / 23 / 2004$ & 315 & 16 & 3063 & 7 & 1.21 \\
\hline $5 / 24 / 2004$ & 140 & 6 & 3830 & 5 & -- \\
\hline Mean & 335 & 12 & 3086 & 5 & 1.85 \\
\hline Std. Dev. & 84 & 4 & 432 & 2 & 0.80 \\
\hline
\end{tabular}


Table B.9. Nutrients (mg/L)

\begin{tabular}{|c|c|c|c|c|}
\hline \multicolumn{1}{|l}{ Head Box } & \multicolumn{5}{l|}{} \\
\hline Date & $\mathbf{N O}_{2}$ & $\mathbf{N O}_{3}$ & TP & TAN \\
\hline $10 / 8 / 2003$ & $<0.01$ & 0.68 & 0.064 & 2.23 \\
\hline $11 / 17 / 2003$ & $<0.01$ & 0.19 & 0.067 & 2.32 \\
\hline $1 / 20 / 2004$ & $<0.01$ & 0.15 & 0.063 & 2.50 \\
\hline $2 / 20 / 2004$ & $<0.01$ & 0.19 & $<0.01$ & 2.40 \\
\hline $3 / 22 / 2004$ & $<0.01$ & 0.18 & 0.060 & 2.51 \\
\hline $4 / 23 / 2004$ & $<0.01$ & 0.14 & 0.032 & 2.88 \\
\hline $5 / 24 / 2004$ & -- & -- & -- & 2.43 \\
\hline Mean & $<0.01$ & 0.26 & 0.257 & 2.47 \\
\hline Std. Dev. & & 0.21 & 0.014 & 0.21 \\
\hline
\end{tabular}

\begin{tabular}{|c|c|c|c|c|}
\hline \multicolumn{5}{|c|}{ A4 } \\
\hline Date & NO $_{2}$ & NO $_{3}$ & TP & TAN \\
\hline $10 / 8 / 2003$ & $<0.01$ & 0.76 & 0.110 & 2.20 \\
\hline $11 / 17 / 2003$ & 0.03 & 0.20 & 0.100 & 2.34 \\
\hline $1 / 20 / 2004$ & $<0.01$ & 0.23 & 0.042 & 2.52 \\
\hline $2 / 20 / 2004$ & $<0.01$ & 0.22 & 0.186 & 2.86 \\
\hline $3 / 22 / 2004$ & $<0.01$ & 0.23 & 0.120 & 2.82 \\
\hline $4 / 23 / 2004$ & $<0.01$ & 0.18 & 0.130 & 2.62 \\
\hline $5 / 24 / 2004$ & -- & -- & -- & 2.55 \\
\hline Mean & $<0.01$ & 0.30 & 0.115 & 2.56 \\
\hline Std. Dev. & & 0.22 & 0.047 & 0.24 \\
\hline
\end{tabular}

\begin{tabular}{|c|c|c|c|c|}
\hline \multicolumn{1}{|c|}{ B4 } & \multicolumn{4}{l|}{} \\
\hline Date & NO $_{2}$ & NO $_{3}$ & TP & TAN \\
\hline $10 / 8 / 2003$ & $<0.01$ & 0.68 & 0.120 & 2.35 \\
\hline $11 / 17 / 2003$ & $<0.01$ & 0.19 & 0.105 & 2.34 \\
\hline $1 / 20 / 2004$ & $<0.01$ & 0.16 & 0.056 & 2.38 \\
\hline $2 / 20 / 2004$ & $<0.01$ & 0.19 & 0.020 & 2.42 \\
\hline $3 / 22 / 2004$ & $<0.01$ & 0.19 & 0.156 & 2.76 \\
\hline $4 / 23 / 2004$ & $<0.01$ & 0.15 & 0.117 & 2.52 \\
\hline $5 / 24 / 2004$ & -- & -- & -- & 2.59 \\
\hline Mean & $<0.01$ & 0.26 & 0.096 & 2.48 \\
\hline Std. Dev. & & 0.21 & 0.049 & 0.15 \\
\hline
\end{tabular}


Table B.10. Unionized Ammonia (mg/L)

\begin{tabular}{|c|c|c|c|c|c|c|}
\hline \multicolumn{7}{|l|}{ Head Box } \\
\hline Date & $\begin{array}{c}\text { TAN } \\
(\mathrm{mg} / \mathrm{L})\end{array}$ & $\begin{array}{c}\text { Temperature } \\
\left({ }^{\circ} \mathrm{C}\right)\end{array}$ & pH & $\begin{array}{l}\text { Sp.Cond. } \\
\text { (mS/cm) }\end{array}$ & $f$ & $\begin{array}{c}\text { Un-Ionized } \\
\text { Ammonia } \\
(\mathrm{mg} / \mathrm{L})\end{array}$ \\
\hline $10 / 8 / 2003$ & 2.23 & 14.8 & 7.75 & 6.67 & 0.00483332 & 0.011 \\
\hline $11 / 17 / 2003$ & 2.32 & 9.4 & 7.94 & 6.29 & 0.00498435 & 0.012 \\
\hline $1 / 20 / 2004$ & 2.50 & 6.4 & 8.20 & 6.18 & 0.00715898 & 0.018 \\
\hline $2 / 20 / 2004$ & 2.40 & 8.2 & 7.96 & 5.94 & 0.00475568 & 0.011 \\
\hline $3 / 22 / 2004$ & 2.51 & 10.1 & 7.86 & 6.27 & 0.00438261 & 0.011 \\
\hline $4 / 23 / 2004$ & 2.88 & 12.8 & 7.66 & 6.06 & 0.00338896 & 0.010 \\
\hline $5 / 24 / 2004$ & 2.43 & 21.7 & 8.20 & 6.25 & 0.0219964 & 0.053 \\
\hline
\end{tabular}

\begin{tabular}{|c|c|c|c|c|c|c|}
\hline \multicolumn{7}{|l|}{ A4 } \\
\hline Date & $\begin{array}{c}\text { TAN } \\
(\mathrm{mg} / \mathrm{L})\end{array}$ & $\begin{array}{c}\text { Temperature } \\
\left({ }^{\circ} \mathrm{C}\right)\end{array}$ & pH & $\begin{array}{l}\text { Sp.Cond. } \\
\text { (mS/cm) }\end{array}$ & $f$ & $\begin{array}{c}\text { Un-Ionized } \\
\text { Ammonia } \\
\text { (mg/L) }\end{array}$ \\
\hline $10 / 8 / 2003$ & 2.20 & 14.7 & 7.80 & 6.66 & 0.00537906 & 0.012 \\
\hline $11 / 17 / 2003$ & 2.34 & 9.2 & 7.91 & 6.26 & 0.00458056 & 0.011 \\
\hline $1 / 20 / 2004$ & 2.52 & 6.2 & 8.40 & 6.15 & 0.0111199 & 0.028 \\
\hline $2 / 20 / 2004$ & 2.86 & 8.0 & 7.99 & 5.96 & 0.00501433 & 0.014 \\
\hline $3 / 22 / 2004$ & 2.82 & 9.9 & 7.96 & 6.22 & 0.00542538 & 0.015 \\
\hline 4/23/2004 & 2.62 & 12.7 & 7.43 & 6.10 & 0.00198321 & 0.005 \\
\hline $5 / 24 / 2004$ & 2.55 & 21.7 & 7.78 & 6.27 & 0.00847869 & 0.022 \\
\hline
\end{tabular}

\begin{tabular}{|c|c|c|c|c|c|c|}
\hline B4 & \multicolumn{7}{|c|}{$\begin{array}{c}\text { TAN } \\
\text { Date }\end{array}$} & $\begin{array}{c}\text { Temperature } \\
(\mathbf{m g / L})\end{array}$ & $\begin{array}{c}\text { ( } \mathbf{C}) \\
\text { Sp.Cond. }\end{array}$ & $\mathbf{p H}$ & $\begin{array}{c}\text { Un-Ionized } \\
\text { AmS/cm) }\end{array}$ & $\boldsymbol{f}$ & $\begin{array}{c}\text { Amonia } \\
(\mathbf{m g} / \mathbf{L})\end{array}$ \\
\hline $10 / 8 / 2003$ & 2.35 & 14.7 & 7.86 & 6.66 & 0.00617107 & 0.015 \\
\hline $11 / 17 / 2003$ & 2.34 & 9.1 & 7.90 & 6.27 & 0.00444182 & 0.010 \\
\hline $1 / 20 / 2004$ & 2.38 & 6.3 & 8.40 & 6.19 & 0.01120956 & 0.027 \\
\hline $2 / 20 / 2004$ & 2.42 & 8.0 & 7.98 & 5.95 & 0.00490066 & 0.012 \\
\hline $3 / 22 / 2004$ & 2.76 & 9.9 & 7.96 & 6.22 & 0.00542538 & 0.015 \\
\hline $4 / 23 / 2004$ & 2.52 & 12.7 & 7.51 & 6.10 & 0.00238339 & 0.006 \\
\hline $5 / 24 / 2004$ & 2.59 & 21.7 & 7.87 & 6.27 & 0.01041074 & 0.027 \\
\hline
\end{tabular}


Table B.11. Metals (mg/L)

\begin{tabular}{|c|c|c|c|c|c|c|c|c|}
\hline \multicolumn{9}{|l|}{ Head Box } \\
\hline Date & $\mathbf{F e}$ & Al & Mn & $\mathrm{Ca}$ & Mg & $\mathbf{N i}$ & $\mathbf{Z n}$ & $\mathbf{C u}$ \\
\hline $10 / 8 / 2003$ & 0.09 & $<0.05$ & 0.27 & 367 & 104 & 0.07 & 0.04 & 0.01 \\
\hline $11 / 17 / 2003$ & 0.05 & $<0.05$ & 0.29 & 370 & 108 & 0.06 & 0.03 & 0.03 \\
\hline $12 / 18 / 2003$ & 0.17 & $<0.05$ & 0.37 & 358 & 105 & 0.02 & $<0.01$ & $<0.01$ \\
\hline $1 / 20 / 2004$ & 0.37 & $<0.05$ & 0.35 & 365 & 102 & 0.01 & $<0.01$ & $<0.01$ \\
\hline $2 / 20 / 2004$ & 0.04 & $<0.05$ & 0.48 & 364 & 86 & 0.05 & 0.02 & 0.02 \\
\hline $3 / 22 / 2004$ & 0.05 & $<0.05$ & 0.40 & 355 & 83 & 0.01 & 0.03 & 0.01 \\
\hline Mean & 0.13 & $<0.05$ & 0.36 & 363 & 98 & 0.04 & 0.03 & 0.02 \\
\hline Std. Dev. & 0.13 & & 0.08 & 6 & 11 & 0.03 & 0.01 & 0.01 \\
\hline
\end{tabular}

\begin{tabular}{|c|c|c|c|c|c|c|c|c|}
\hline \multicolumn{10}{|c|}{ A4 } \\
\hline Date & Fe & Al & Mn & Ca & Mg & Ni & Zn & Cu \\
\hline $10 / 8 / 2003$ & 0.1 & $<0.05$ & 0.26 & 356 & 97 & 0.06 & 0.03 & 0.01 \\
\hline $11 / 17 / 2003$ & 0.06 & $<0.05$ & 0.31 & 363 & 105 & 0.04 & 0.04 & 0.03 \\
\hline $12 / 18 / 2003$ & 0.11 & $<0.05$ & 0.37 & 354 & 102 & 0.02 & $<0.01$ & $<0.01$ \\
\hline $1 / 20 / 2004$ & 0.35 & $<0.05$ & 0.36 & 350 & 96 & 0.01 & $<0.01$ & $<0.01$ \\
\hline $2 / 20 / 2004$ & 0.04 & $<0.05$ & 0.48 & 360 & 85 & 0.05 & 0.07 & 0.02 \\
\hline 3/22/2004 & 0.05 & $<0.05$ & 0.41 & 353 & 84 & 0.01 & 0.02 & 0.01 \\
\hline Mean & 0.12 & $<0.05$ & 0.37 & 356 & 95 & 0.03 & 0.04 & 0.02 \\
\hline Std. Dev. & 0.12 & & 0.08 & 5 & 9 & 0.02 & 0.02 & 0.01 \\
\hline
\end{tabular}

\begin{tabular}{|c|c|c|c|c|c|c|c|c|}
\hline \multicolumn{10}{|c|}{ B4 } \\
\hline Date & Fe & Al & Mn & Ca & Mg & Ni & Zn & Cu \\
\hline $10 / 8 / 2003$ & 0.11 & $<0.05$ & 0.27 & 359 & 97 & 0.09 & 0.03 & 0.01 \\
\hline $11 / 17 / 2003$ & 0.07 & $<0.05$ & 0.3 & 361 & 103 & 0.05 & 0.04 & 0.02 \\
\hline $12 / 18 / 2003$ & 0.07 & $<0.05$ & 0.35 & 368 & 101 & 0.02 & $<0.01$ & $<0.01$ \\
\hline $1 / 20 / 2004$ & 0.37 & $<0.05$ & 0.35 & 349 & 96 & 0.01 & $<0.01$ & $<0.01$ \\
\hline $2 / 20 / 2004$ & 0.04 & $<0.05$ & 0.47 & 356 & 83 & 0.05 & 0.02 & 0.02 \\
\hline $3 / 22 / 2004$ & 0.07 & $<0.05$ & 0.41 & 350 & 84 & 0.01 & 0.03 & 0.01 \\
\hline Mean & 0.12 & $<0.05$ & 0.36 & 357 & 94 & 0.04 & 0.03 & 0.02 \\
\hline Std. Dev. & 0.12 & & 0.07 & 7 & 9 & 0.03 & 0.01 & 0.01 \\
\hline
\end{tabular}


Table B.12. Fish Sampling

\begin{tabular}{|c|c|c|c|c|c|c|c|c|c|c|c|c|c|c|c|c|c|c|}
\hline \multicolumn{19}{|l|}{ A1 } \\
\hline Sample Date & \multicolumn{2}{|c|}{$10 / 14 / 2003$} & \multicolumn{2}{|c|}{$11 / 17 / 2003$} & \multirow{2}{*}{\multicolumn{2}{|c|}{$\begin{array}{c}12 / 18 / 2003 \\
78 \\
\end{array}$}} & \multicolumn{2}{|c|}{$1 / 20 / 2004$} & \multicolumn{2}{|c|}{$2 / 19 / 2004$} & \multicolumn{3}{|c|}{$3 / 22 / 2004$} & \multicolumn{3}{|c|}{$4 / 23 / 2004$} & \multicolumn{2}{|c|}{$5 / 24 / 2004$} \\
\hline \# Fish & \multicolumn{2}{|c|}{53} & 28 & 35 & & & 38 & 34 & 31 & 28 & \multicolumn{2}{|c|}{49} & 13 & 23 & 15 & 13 & 21 & 29 \\
\hline wt (kg) & \multicolumn{2}{|c|}{4.72} & 4.10 & 5.02 & \multicolumn{2}{|c|}{14.54} & 8.24 & 7.42 & 6.82 & 7.16 & \multicolumn{2}{|c|}{12.22} & 3.68 & 9.15 & 5.64 & 5.56 & 9.36 & 13.18 \\
\hline \multirow[t]{42}{*}{ Avg (g/fish) } & \multicolumn{2}{|c|}{89} & 146 & 143 & \multicolumn{2}{|c|}{186} & 217 & 218 & 220 & 256 & & & 283 & 398 & 376 & 428 & 446 & 454 \\
\hline & lengt & $(\mathrm{cm})$ & leng & $(\mathrm{cm})$ & lengt & $(\mathrm{cm})$ & lengt & $(\mathrm{cm})$ & leng & $(\mathrm{cm})$ & & igth ( & & & igth ( & & lens & $(\mathrm{cm})$ \\
\hline & 20 & 19 & 26.5 & 25 & 27 & 23 & 26.2 & 22.4 & 31.9 & 27.4 & 28.5 & 28.2 & 34.3 & 33.1 & 34.2 & 30.2 & 35.2 & 35.3 \\
\hline & 20.8 & 19.6 & 22 & 22.1 & 23.3 & 24.1 & 26.1 & 25.6 & 27.5 & 30.9 & 26.2 & 28.9 & 29.5 & 30.3 & 31.5 & 31.7 & 32.3 & 34.6 \\
\hline & 21.3 & 20.4 & 24.4 & 22.8 & 23 & 27.4 & 27.1 & 26.6 & 25.6 & 26.4 & 24.5 & 26 & 27.2 & 32.1 & 30.2 & 33.4 & 30.5 & 30 \\
\hline & 20.6 & 18.5 & 22.2 & 24.6 & 25 & 24.2 & 26 & 25.2 & 23.1 & 24.1 & 30.4 & 27.8 & 28.1 & 34.2 & 30.5 & 31.1 & 36.1 & 32.2 \\
\hline & 18.5 & 21.2 & 24.2 & 23 & 27.1 & 21.9 & 27.5 & 23.6 & 27.2 & 27 & 30.6 & 31.1 & 30 & 28.5 & 31.6 & 32.9 & 33.3 & 33.1 \\
\hline & 21 & 19.9 & 22.3 & 23.4 & 26.4 & 24.4 & 24 & 28 & 24.3 & 27.4 & 27.7 & 28.4 & 27.3 & 31.6 & 29 & 30.3 & 32.7 & 31.2 \\
\hline & 21.5 & 17.5 & 23.2 & 25.2 & 24.1 & 25.5 & 27.9 & 28 & 23.8 & 25 & 28.9 & 26.6 & 31.2 & 34.5 & 31.5 & 34.5 & 35.6 & 33.3 \\
\hline & 17.3 & 20 & 19.7 & 17.9 & 26.1 & 26.7 & 26.3 & 27.2 & 25.6 & 27.6 & 25.5 & 22.4 & 25.4 & 30.2 & 30.1 & 32 & 31.7 & 32.6 \\
\hline & 19 & 20 & 27.2 & 17.1 & 24.5 & 24.4 & 27.7 & 27.6 & 25.3 & 20.8 & 30.2 & 28.5 & 27.3 & 26.2 & 32.1 & 31.7 & 34.2 & 31.9 \\
\hline & 21.3 & 17.9 & 20.9 & 23.5 & 25.5 & 25.1 & 28.2 & 27 & 25.6 & 31.6 & 32 & & 26.2 & 32.3 & 30.1 & 27.2 & 33.8 & 32 \\
\hline & 20.2 & 18 & 20.8 & 22.4 & 27.4 & 22.9 & 26.4 & 30.8 & 24.6 & 29.4 & 28.6 & & 29.5 & 31.7 & 29.9 & 28.9 & 32 & 32.9 \\
\hline & 22.1 & 21.3 & 25.2 & 18.3 & 26.1 & 23.2 & 27.8 & 25.1 & 26.2 & 26.3 & 31.1 & & 27 & 34.2 & 29 & 33 & 28.3 & 31.6 \\
\hline & 22.8 & 21.3 & 22.8 & 21.7 & 26.5 & 24.1 & 29.1 & 24.4 & 25.7 & 25.1 & 27.2 & & 26.1 & 31.1 & 26.7 & 30 & 32.6 & 34.1 \\
\hline & 23 & & 22.6 & 23 & 18.9 & 25.1 & 27.5 & 23 & 26.1 & 28.5 & 30.3 & & & 33 & 28.1 & & 32.8 & 31.5 \\
\hline & 18.7 & & 24.3 & 21.7 & 23.1 & 24.2 & 27.1 & 27.1 & 24.2 & 26.2 & 28.3 & & & 31.6 & 29.5 & & 34.5 & 35.3 \\
\hline & 17 & & 24.3 & 19 & 24.1 & 28.1 & 24.7 & 26.8 & 26.6 & 27.2 & 31.5 & & & 33.4 & & & 32.3 & 31.2 \\
\hline & 23.8 & & 23 & 25.1 & 27.9 & 25.5 & 30.3 & 27.5 & 26.4 & 27.3 & 30.4 & & & 27.9 & & & 27.1 & 36.3 \\
\hline & 20.3 & & 22.6 & 19.5 & 25.7 & 24 & 30 & 24.1 & 27.5 & 27.7 & 28.6 & & & 31.1 & & & 27.8 & 35.5 \\
\hline & 20.6 & & 22.9 & 24.9 & 21.3 & 25.2 & 26.1 & 28.2 & 22.6 & 26.4 & 31.5 & & & 32 & & & 33.3 & 32.8 \\
\hline & 20.5 & & 22.2 & 23.6 & 25.6 & 25.5 & 28 & 28.7 & 25.6 & 27.1 & 30.5 & & & 30.7 & & & 31 & 30.7 \\
\hline & 20.5 & & 24.6 & 23.2 & 24.7 & 22.9 & 27.5 & 27.2 & 26.2 & 27.6 & 30.4 & & & 30.2 & & & 27.8 & 33.5 \\
\hline & 21.5 & & 15 & 25 & 23.1 & 26.5 & 25.3 & 25.7 & 27.7 & 25.7 & 28.6 & & & 26.5 & & & & 35 \\
\hline & 20.8 & & 22.4 & 23 & 23.8 & 23.4 & 24.5 & 25.9 & 26.2 & 28.7 & 31.5 & & & 28.2 & & & & 31.2 \\
\hline & 18.3 & & 21.5 & 23 & 24.5 & 22.9 & 24 & 25.6 & 25.3 & 24.6 & 30.4 & & & & & & & 27.6 \\
\hline & 18.7 & & 26.1 & 22.5 & 26.6 & 23 & 21.5 & 25 & 26.4 & 27.7 & 28.6 & & & & & & & 34.3 \\
\hline & 21.2 & & 20.3 & 22.9 & 22.6 & 27.1 & 27.6 & 28.3 & 20.7 & 26.1 & 31.5 & & & & & & & 30 \\
\hline & 20.3 & & 23 & 22.2 & 24.9 & 26.2 & 26.2 & 24.7 & 25.2 & 25.5 & 30.5 & & & & & & & 29.1 \\
\hline & 17.6 & & 24.9 & 24.7 & 23.5 & 24.1 & 25.5 & 24.6 & 26.2 & 26.8 & 30.4 & & & & & & & 33.1 \\
\hline & 22.2 & & & 22.7 & 25.2 & 25.5 & 23.9 & 25.2 & 29.3 & & 27.7 & & & & & & & 25.9 \\
\hline & 19.3 & & & 24 & 26.9 & 28.4 & 25.5 & 25.5 & 25.7 & & 26 & & & & & & & \\
\hline & 21.2 & & & 23.5 & 22.5 & 25.2 & 25 & 26.7 & 29.4 & & 32.6 & & & & & & & \\
\hline & 17.4 & & & 22.2 & 23.8 & 26.5 & 24.6 & 25.3 & & & 28.8 & & & & & & & \\
\hline & 20.2 & & & 23.1 & 24.6 & 22.5 & 25.2 & 24.5 & & & 29 & & & & & & & \\
\hline & 17.6 & & & 25.7 & 22.9 & 25.1 & 24.8 & 26 & & & 26.4 & & & & & & & \\
\hline & 19.5 & & & 24.8 & 23.6 & 22.5 & 24.9 & 20 & & & 30.4 & & & & & & & \\
\hline & 22 & & & & 23.5 & 23.1 & 27 & & & & 26.7 & & & & & & & \\
\hline & 21.2 & & & & 24.7 & 25.9 & 21.7 & & & & 30.6 & & & & & & & \\
\hline & 20 & & & & 26 & 26.9 & 17.3 & & & & 26.1 & & & & & & & \\
\hline & 21.1 & & & & 25 & & 26.8 & & & & 33.1 & & & & & & & \\
\hline & 17.1 & & & & 25.5 & & & & & & 27 & & & & & & & \\
\hline
\end{tabular}


Table B.12. Fish Sampling

\begin{tabular}{|c|c|c|c|c|c|c|c|c|c|c|c|c|c|c|c|c|c|}
\hline \multicolumn{18}{|c|}{ A2 } \\
\hline Sample Date & \multirow{2}{*}{\multicolumn{2}{|c|}{$\begin{array}{c}10 / 14 / 2003 \\
53 \\
\end{array}$}} & \multicolumn{2}{|c|}{$11 / 17 / 2003$} & \multirow{2}{*}{\multicolumn{2}{|c|}{$\begin{array}{c}12 / 18 / 2003 \\
54 \\
\end{array}$}} & \multicolumn{2}{|c|}{$1 / 20 / 2004$} & \multicolumn{2}{|c|}{$2 / 19 / 2004$} & \multirow{2}{*}{\multicolumn{2}{|c|}{$\begin{array}{c}3 / 22 / 2004 \\
50 \\
\end{array}$}} & \multicolumn{3}{|c|}{$4 / 23 / 2004$} & \multicolumn{2}{|c|}{$5 / 24 / 2004$} \\
\hline \# Fish & & & 36 & 13 & & & 43 & 30 & 30 & 29 & & & 20 & 14 & 19 & 22 & 35 \\
\hline wt (kg) & \multicolumn{2}{|c|}{4.72} & 5.18 & 2.12 & \multicolumn{2}{|c|}{9.98} & 9.58 & 6.70 & 8.44 & 7.72 & \multicolumn{2}{|c|}{15.22} & 8.58 & 6.30 & 7.82 & 11.64 & 16.58 \\
\hline \multirow[t]{46}{*}{ Avg (g/fish) } & \multicolumn{2}{|c|}{89} & 144 & 163 & \multicolumn{2}{|c|}{185} & 223 & 223 & 281 & 266 & & & 429 & 450 & 412 & 529 & 474 \\
\hline & leng & $(\mathrm{cm})$ & lengt & $(\mathrm{cm})$ & lengt & $(\mathrm{cm})$ & lengt & $(\mathrm{cm})$ & lengt & $(\mathrm{cm})$ & lengt & $(\mathrm{cm})$ & & igth (c & & lengt & $(\mathrm{cm})$ \\
\hline & 20 & 21.2 & 23.8 & 19.2 & 25.6 & 26 & 29 & 24.5 & 31.3 & 28.7 & 32.9 & 30.3 & 35.2 & 33.2 & 31.3 & 29 & 32.2 \\
\hline & 20.8 & 19.9 & 19.7 & 21.6 & 25.1 & 25.2 & 22.8 & 28 & 30.3 & 26.6 & 29.6 & 31.7 & 34.6 & 37.8 & 31.5 & 35.3 & 31.8 \\
\hline & 21.3 & 17.5 & 21.2 & 21.4 & 23.2 & 26.1 & 27.8 & 25.4 & 24.9 & 27.6 & 27.1 & 26.1 & 33.7 & 32 & 30.6 & 39.3 & 33.3 \\
\hline & 20.6 & 20 & 25.5 & 23 & 21.8 & 24.5 & 27 & 23.3 & 24.7 & 30.6 & 34.1 & 28 & 31.6 & 32.3 & 32.7 & 35 & 37.1 \\
\hline & 18.5 & 20 & 21.5 & 22.3 & 25.1 & 24 & 24.8 & 26.8 & 27.6 & 29.9 & 29 & 23.3 & 30.1 & 33.2 & 30.6 & 38.1 & 34.5 \\
\hline & 21 & 17.9 & 24 & 23.1 & 25.4 & 25.6 & 29.2 & 25.6 & 33.5 & 27.6 & 26.9 & 24.9 & 28.6 & 32.6 & 33.1 & 33 & 34.7 \\
\hline & 21.5 & 18 & 22.2 & 24.3 & 24.3 & 23.8 & 23.4 & 21.5 & 29.3 & 28.7 & 27.5 & & 27.7 & 31.2 & 31.1 & 30.9 & 29.6 \\
\hline & 17.3 & 21.3 & 18.7 & 25 & 22.9 & 27.5 & 28.7 & 27.8 & 26.9 & 28 & 27.6 & & 28.3 & 30.2 & 34.4 & 34.2 & 33.4 \\
\hline & 19 & 21.3 & 25.4 & 25 & 26.2 & 28.1 & 29.5 & 29.4 & 26.4 & 24 & 30.5 & & 34.5 & 25.6 & 29 & 36.6 & 33.2 \\
\hline & 21.3 & & 22.9 & 25.6 & 25 & 21.2 & 26.3 & 27 & 28.2 & 28.2 & 26.1 & & 34.8 & 31.3 & 29.3 & 34.5 & 32.5 \\
\hline & 20.2 & & 23.4 & 27 & 23.5 & 20.6 & 27.4 & 29 & 30.4 & 26.7 & 30.1 & & 27.5 & 32.2 & 32.1 & 34.5 & 32.2 \\
\hline & 22.1 & & 21.7 & 20.5 & 25 & & 28.5 & 26.6 & 28.2 & 27.6 & 27 & & 32.5 & 34.6 & 32.2 & 39 & 31.7 \\
\hline & 22.8 & & 18.9 & 25.9 & 22.7 & & 26.7 & 24.3 & 25.6 & 29.9 & 31.9 & & 30.6 & 33.1 & 29.9 & 33.2 & 33.8 \\
\hline & 23 & & 19 & & 24.8 & & 23.2 & 28 & 22.4 & 25.4 & 29.1 & & 32.8 & 27.9 & 30.5 & 37.7 & 33.7 \\
\hline & 18.7 & & 17 & & 22 & & 25.6 & 27.8 & 23.3 & 29.8 & 32.6 & & 30.7 & & 31.5 & 31.5 & 36.5 \\
\hline & 17 & & 24 & & 26.9 & & 25.9 & 23 & 29.2 & 27.1 & 31 & & 31.1 & & 30.4 & 34.7 & 35.1 \\
\hline & 23.8 & & 25.7 & & 25.8 & & 28.6 & 26 & 29.5 & 29.4 & 30.9 & & 28.8 & & 31.1 & 31.6 & 34.6 \\
\hline & 20.3 & & 19.7 & & 22.5 & & 26.7 & 26 & 27.9 & 27.3 & 32.7 & & 29.5 & & 32.5 & 32.3 & 28.1 \\
\hline & 20.6 & & 24.8 & & 22 & & 26.9 & 24.6 & 25.5 & 24.5 & 28.6 & & 30.2 & & 29.3 & 32.8 & 32.1 \\
\hline & 20.5 & & 21.3 & & 25.6 & & 26.5 & 29 & 31.2 & 29 & 29.3 & & 30.8 & & & 33.1 & 36.3 \\
\hline & 20.5 & & 21.3 & & 23.5 & & 28.6 & 26.3 & 29.5 & 29.1 & 28.8 & & & & & 33 & 26.3 \\
\hline & 21.5 & & 21 & & 21.2 & & 23.7 & 26.8 & 23.7 & 28.8 & 30.1 & & & & & 32.5 & 33.5 \\
\hline & 20.8 & & 23.3 & & 25.2 & & 26.3 & 29.2 & 28.7 & 26.9 & 29.3 & & & & & & 27 \\
\hline & 18.3 & & 23.3 & & 26.6 & & 28.6 & 23.9 & 24 & 27.3 & 28.9 & & & & & & 36.3 \\
\hline & 18.7 & & 25.2 & & 28 & & 28.7 & 29.1 & 27.6 & 26.2 & 27.2 & & & & & & 32.1 \\
\hline & 21.2 & & 24.2 & & 26.4 & & 28.9 & 24.4 & 29.4 & 28.1 & 33.4 & & & & & & 35.4 \\
\hline & 20.3 & & 25.9 & & 26 & & 25.7 & 24.6 & 28.2 & 27.7 & 31.5 & & & & & & 34.8 \\
\hline & 17.6 & & 19.1 & & 27.7 & & 29.1 & 25.9 & 26.1 & 28 & 31.8 & & & & & & 33 \\
\hline & 22.2 & & 21.8 & & 21.3 & & 26.5 & 25.8 & 28.8 & 24.6 & 26.3 & & & & & & 31.7 \\
\hline & 19.3 & & 23.5 & & 25 & & 22.7 & 26.7 & 28.2 & & 30.1 & & & & & & 35.7 \\
\hline & 21.2 & & 25.4 & & 25.6 & & 25.3 & 26.2 & & & 28.5 & & & & & & 32.9 \\
\hline & 17.4 & & 21.7 & & 26.2 & & 27.2 & & & & 28.6 & & & & & & 33 \\
\hline & 20.2 & & 21.4 & & 25.7 & & 24.7 & & & & 31.6 & & & & & & 35.7 \\
\hline & 17.6 & & 18 & & 27 & & 30 & & & & 30.7 & & & & & & 24.8 \\
\hline & 19.5 & & 23 & & 21.9 & & 29.6 & & & & 25.2 & & & & & & \\
\hline & 22 & & 21.3 & & 24 & & 25.0 & & & & 28.3 & & & & & & \\
\hline & 21.2 & & & & 23.1 & & 18 & & & & 29.2 & & & & & & \\
\hline & 20 & & & & 23.6 & & 27.1 & & & & 24.9 & & & & & & \\
\hline & 21.1 & & & & 24.6 & & 26.7 & & & & 27.8 & & & & & & \\
\hline & 17.1 & & & & 24.1 & & 25.2 & & & & 25.8 & & & & & & \\
\hline & 19 & & & & 25.2 & & 23.2 & & & & 27.9 & & & & & & \\
\hline & 19.6 & & & & 26.3 & & 22.2 & & & & 29 & & & & & & \\
\hline & 20.4 & & & & 25.4 & & 25.1 & & & & 28 & & & & & & \\
\hline & 18.5 & & & & 26.9 & & 28 & & & & 28.6 & & & & & & \\
\hline
\end{tabular}


Table B.12. Fish Sampling

\begin{tabular}{|c|c|c|c|c|c|c|c|c|c|c|c|c|c|c|c|c|}
\hline \multicolumn{17}{|l|}{ A3 } \\
\hline Sample Date & \multirow{2}{*}{\multicolumn{2}{|c|}{$\begin{array}{c}10 / 14 / 2003 \\
53 \\
\end{array}$}} & \multirow{2}{*}{\multicolumn{2}{|c|}{$\begin{array}{c}11 / 17 / 2003 \\
60 \\
\end{array}$}} & \multirow{2}{*}{\multicolumn{2}{|c|}{$\begin{array}{c}12 / 18 / 2003 \\
53 \\
\end{array}$}} & \multicolumn{2}{|c|}{$1 / 20 / 2004$} & \multicolumn{2}{|c|}{ 2/19/2004 } & \multirow{2}{*}{\multicolumn{2}{|c|}{$\begin{array}{c}3 / 22 / 2004 \\
51 \\
\end{array}$}} & \multirow{2}{*}{\multicolumn{2}{|c|}{$\begin{array}{c}4 / 23 / 2004 \\
50 \\
\end{array}$}} & \multirow{2}{*}{\multicolumn{2}{|c|}{$\begin{array}{c}5 / 24 / 2004 \\
55 \\
\end{array}$}} \\
\hline \# Fish & & & & & & & 35 & 31 & 34 & 27 & & & & & & \\
\hline wt (kg) & \multicolumn{2}{|c|}{4.72} & \multicolumn{2}{|c|}{9.02} & \multicolumn{2}{|c|}{10.88} & 7.94 & 7.32 & 8.90 & 7.30 & \multicolumn{2}{|c|}{15.04} & \multicolumn{2}{|c|}{23.56} & \multicolumn{2}{|c|}{27.54} \\
\hline Avg (g/fish) & & & & & & & 227 & 236 & 262 & 270 & & & & & & \\
\hline & lengt & $(\mathrm{cm})$ & lengt & $(\mathrm{cm})$ & lengt & $(\mathrm{cm})$ & lengt & $(\mathrm{cm})$ & leng & $(\mathrm{cm})$ & leng & $(\mathrm{cm})$ & lengt & $(\mathrm{cm})$ & leng & $(\mathrm{cm})$ \\
\hline & 20 & 19.9 & 22.6 & 21.5 & 26.4 & 25.4 & 27 & 27.4 & 24.1 & 27.1 & 30 & 30.8 & 36.8 & 30.6 & 34.6 & 32.5 \\
\hline & 20.8 & 17.5 & 23.2 & 25.6 & 24.9 & 27.5 & 24.5 & 25.5 & 28.8 & 27 & 23.1 & 27.7 & 33.5 & 32.3 & 35.8 & 36.2 \\
\hline & 21.3 & 20 & 23.5 & 24.7 & 26 & 23 & 26.9 & 24.9 & 24 & 25.4 & 27.5 & 27 & 28.4 & 33.9 & 32.8 & 37.5 \\
\hline & 20.6 & 20 & 21.3 & 18.8 & 25 & 25.3 & 25 & 24.8 & 24.6 & 26.8 & 27.9 & 29.6 & 29.5 & 33.2 & 31.7 & 30.7 \\
\hline & 18.5 & 17.9 & 25.7 & 21.5 & 28.7 & 25.6 & 27.4 & 24.6 & 26.6 & 27.7 & 27.3 & 22.9 & 30.3 & & 31.8 & 36.5 \\
\hline & 21 & 18 & 21.4 & 23.2 & 25.9 & 25.1 & 28.6 & 28 & 25.2 & 30.7 & 28.1 & 30.2 & 31.7 & & 23.5 & 32.6 \\
\hline & 21.5 & 21.3 & 23.1 & 23.6 & 27.1 & 23.4 & 28.6 & 28.8 & 24.1 & 26 & 28.7 & & 34.1 & & 34.4 & 33 \\
\hline & 17.3 & 21.3 & 24.7 & 19.2 & 21 & 25.5 & 24 & 28.9 & 27.2 & 25 & 29 & & 35.1 & & 33.1 & 33.6 \\
\hline & 19 & & 21.6 & 20.7 & 27.5 & 27.9 & 26.9 & 28.4 & 28.9 & 27.8 & 30.6 & & 33.2 & & 32.2 & 34.1 \\
\hline & 21.3 & & 22.4 & 24.2 & 23 & & 28.1 & 28.7 & 25.4 & 28.1 & 27.5 & & 30.7 & & 36.2 & 33 \\
\hline & 20.2 & & 22.3 & 24.7 & 26.1 & & 24.6 & 22.6 & 31.3 & 28.9 & 28.2 & & 30.4 & & 30.6 & \\
\hline & 22.1 & & 23.3 & 20.3 & 26 & & 27.7 & 27.8 & 25.6 & 30 & 30.1 & & 33.3 & & 30 & \\
\hline & 22.8 & & 21.7 & 17.3 & 27.2 & & 28.1 & 30.1 & 25.1 & 27.9 & 29.9 & & 33.3 & & 34.6 & \\
\hline & 23 & & 21 & 19 & 23 & & 26.7 & 28.2 & 28.2 & 28.1 & 30.6 & & 32.6 & & 26.9 & \\
\hline & 18.7 & & 23.5 & & 25.5 & & 28 & 30.6 & 33.2 & 19.4 & 31.5 & & 31.4 & & 36.4 & \\
\hline & 17 & & 22.6 & & 27.1 & & 27.9 & 26.5 & 29.1 & 27.3 & 31.7 & & 35.4 & & 31 & \\
\hline & 23.8 & & 25 & & 24.7 & & 30 & 23.2 & 27.1 & 26.8 & 31.2 & & 29.6 & & 33 & \\
\hline & 20.3 & & 24.2 & & 26.4 & & 28.5 & 25.4 & 24.8 & 27.2 & 29.3 & & 36.7 & & 31.1 & \\
\hline & 20.6 & & 19.4 & & 27.5 & & 24.4 & 28.1 & 28 & 28.9 & 24.2 & & 31.2 & & 34.8 & \\
\hline & 20.5 & & 22.1 & & 26.9 & & 25.1 & 30 & 27.3 & 29.6 & 27.1 & & 28.4 & & 33 & \\
\hline & 20.5 & & 22.2 & & 26.1 & & 26.2 & 27.1 & 28.5 & 29.7 & 29.6 & & 32.3 & & 33.5 & \\
\hline & 21.5 & & 23.5 & & 23.8 & & 24.6 & 22.9 & 25.8 & 29.3 & 30.6 & & 30.1 & & 33.7 & \\
\hline & 20.8 & & 23.4 & & 26.1 & & 27.9 & 29 & 27.7 & 26.6 & 29.2 & & 26.6 & & 33.6 & \\
\hline & 18.3 & & 19 & & 27.1 & & 26.9 & 28 & 27.9 & 27.5 & 31.1 & & 32.2 & & 29.6 & \\
\hline & 18.7 & & 22.5 & & 27.9 & & 23.6 & 22.5 & 27.6 & 24.9 & 30.8 & & 28.8 & & 34.7 & \\
\hline & 21.2 & & 24.1 & & 28.1 & & 22.8 & 24.6 & 29.5 & 24.7 & 28.5 & & 31.6 & & 21.6 & \\
\hline & 20.3 & & 27.7 & & 23 & & 25.5 & 25.3 & 30.4 & 26.8 & 29.5 & & 30.5 & & 34.1 & \\
\hline & 17.6 & & 25.6 & & 28 & & 28 & 25.5 & 21.9 & & 29.6 & & 34.2 & & 36.6 & \\
\hline & 22.2 & & 21.9 & & 23 & & 26 & 28.9 & 27.1 & & 31.1 & & 30.1 & & 33.8 & \\
\hline & 19.3 & & 22.8 & & 25.9 & & 21.6 & 23 & 27.5 & & 26.9 & & 29.8 & & 31.2 & \\
\hline & 21.2 & & 24.4 & & 24.1 & & 27 & 25.8 & 25.5 & & 31.6 & & 28.3 & & 40.6 & \\
\hline & 17.4 & & 17.5 & & 23.6 & & 26.7 & 23.6 & 28.3 & & 29.2 & & 31.8 & & 31.5 & \\
\hline & 20.2 & & 24.7 & & 23.8 & & 27.9 & & 26.6 & & 27.6 & & 33.5 & & 31.6 & \\
\hline & 17.6 & & 24.8 & & 25.6 & & 26 & & 19 & & 29.1 & & 33.4 & & 36.1 & \\
\hline & 19.5 & & 22.9 & & 24.3 & & 28.1 & & & & 27.2 & & 31.5 & & 33.5 & \\
\hline & 22 & & 24 & & 25 & & 25.0 & & & & 28.1 & & 30.9 & & 36 & \\
\hline & 21.2 & & 20.4 & & 24 & & & & & & 27.7 & & 35.3 & & 32.6 & \\
\hline & 20 & & 25.1 & & 25 & & & & & & 28.8 & & 32.5 & & 36 & \\
\hline & 21.1 & & 24.2 & & 28.3 & & & & & & 30.3 & & 32.3 & & 34.5 & \\
\hline & 17.1 & & 21.7 & & 24.8 & & & & & & 30.6 & & 31.9 & & 34.7 & \\
\hline & 19 & & 23.1 & & 25.5 & & & & & & 28.8 & & 31.1 & & 32.7 & \\
\hline & 19.6 & & 17.8 & & 25.6 & & & & & & 30.6 & & 33.2 & & 34.8 & \\
\hline & 20.4 & & 20.7 & & 29 & & & & & & 31.3 & & 32.2 & & 30.5 & \\
\hline & 18.5 & & 24.7 & & 23.8 & & & & & & 25.3 & & 28.1 & & 36.6 & \\
\hline & 21.2 & & 24.3 & & 26 & & & & & & 27.5 & & 33.1 & & 32.3 & \\
\hline
\end{tabular}


Table B.12. Fish Sampling

\begin{tabular}{|c|c|c|c|c|c|c|c|c|c|c|c|c|c|c|c|c|c|c|}
\hline \multicolumn{19}{|l|}{ B1 } \\
\hline Sample Date & \multirow{2}{*}{\multicolumn{2}{|c|}{$\frac{10 / 14 / 2003}{53}$}} & \multicolumn{2}{|c|}{$11 / 17 / 2003$} & \multicolumn{2}{|c|}{$12 / 18 / 2003$} & \multicolumn{3}{|c|}{$1 / 20 / 2004$} & \multicolumn{2}{|c|}{ 2/19/2004 } & \multicolumn{2}{|c|}{$3 / 22 / 2004$} & \multicolumn{3}{|c|}{$4 / 23 / 2004$} & \multicolumn{2}{|c|}{$5 / 24 / 2004$} \\
\hline \# Fish & & & 40 & 30 & \multicolumn{2}{|c|}{58} & 30 & \multicolumn{2}{|c|}{46} & 47 & 8 & \multicolumn{2}{|c|}{50} & 17 & 30 & 4 & 25 & 27 \\
\hline wt (kg) & \multicolumn{2}{|c|}{4.72} & 5.60 & 4.32 & \multicolumn{2}{|c|}{10.98} & 6.04 & \multicolumn{2}{|c|}{9.78} & 10.16 & 1.66 & & & 6.18 & 9.74 & 0.42 & 10.00 & 11.32 \\
\hline Avg (g/fish) & \multicolumn{2}{|c|}{89} & 140 & 144 & & & 201 & & & 216 & 208 & & & 364 & 325 & 105 & 400 & 419 \\
\hline & lengt & $(\mathrm{cm})$ & lengt & $(\mathrm{cm})$ & lengt & $(\mathrm{cm})$ & & igth (c & & lengtl & $(\mathrm{cm})$ & lengt & $(\mathrm{cm})$ & & igth (c & & lengt & $(\mathrm{cm})$ \\
\hline & 20 & 20.4 & 23 & 22.5 & 24.7 & 25.3 & 24.7 & 27 & 24.3 & 25 & 23.7 & 27.5 & 27.4 & 31 & 30.2 & 29.1 & 32.6 & 35.7 \\
\hline & 20.6 & 19.9 & 21.3 & 24.4 & 20.7 & 25.3 & 26.9 & 32.4 & 23.6 & 25.2 & 27.1 & 29.9 & 27.8 & 28.6 & 30.5 & 30.7 & 34.2 & 34.5 \\
\hline & 18.5 & 17.5 & 22.9 & 23.8 & 21.2 & 27 & 28.1 & 23.4 & 21.5 & 25.9 & 26.5 & 27.8 & 26 & 31.1 & 28.1 & & 29.4 & 33.6 \\
\hline & 21 & 20 & 20 & 25 & 26 & 25.3 & 24.1 & 31 & & 25.1 & 16.6 & 23.6 & 26.7 & 30.6 & 30.3 & & 35.2 & 34.7 \\
\hline & 21.5 & 20 & 20.3 & 22.1 & 25.1 & 27 & 27.2 & 27.6 & & 28.5 & 27 & 25 & 27.2 & 30.5 & 29.4 & & 32.6 & 33.2 \\
\hline & 17.3 & 17.9 & 21.9 & 20.9 & 23.3 & 26.7 & 26.1 & 24.2 & & 23.6 & 25.1 & 26.8 & 28.3 & 30.1 & 34.8 & & 25.1 & 33.5 \\
\hline & 22.8 & & 24.4 & 21.1 & 25.4 & 24.1 & 25.9 & 22.2 & & 27.7 & 25 & 27.7 & & 28 & 26.4 & & 28.4 & 35.9 \\
\hline & 23 & & 18 & 24.8 & 24.7 & 21.6 & 27.5 & 26.8 & & 25.6 & & 31.7 & & 29.3 & 24.3 & & 32.8 & 30.5 \\
\hline & 18.7 & & 24.3 & 21.4 & 23.3 & 21.9 & 25.3 & 27.3 & & 25.7 & & 28.4 & & 28.4 & 24.7 & & 31.6 & 28.3 \\
\hline & 17 & & 24.6 & 22.1 & 25.1 & 25.7 & 25 & 28.1 & & 26.4 & & 30.6 & & 30.3 & 30.4 & & 30 & 33.3 \\
\hline & 23.8 & & 22.7 & 23.3 & 26.2 & 25.2 & 22 & 26.3 & & 22.2 & & 29.1 & & 28.3 & 30.6 & & 29.3 & 28.1 \\
\hline & 20.3 & & 24.7 & 22 & 23.8 & 25.1 & 22.8 & 27.5 & & 27.3 & & 29.5 & & & 32.7 & & 31.7 & 32.2 \\
\hline & 20.6 & & 22.8 & 23.5 & 23.5 & & 26.3 & 24.5 & & 26.4 & & 27 & & & 29.4 & & 30.4 & 27.2 \\
\hline & 20.5 & & 22.2 & 24 & 24.5 & & 26.2 & 27.1 & & 25.4 & & 31 & & & 27.6 & & 29.8 & 30.9 \\
\hline & 20.5 & & 20.9 & 19.7 & 23.1 & & 27 & 23.9 & & 28.1 & & 23.8 & & & 31.7 & & 30.7 & 35.3 \\
\hline & 21.5 & & 19 & 23.7 & 20 & & 16.8 & 24.6 & & 26.1 & & 27.6 & & & 32.4 & & 35.1 & 30.6 \\
\hline & 19.3 & & 24 & & 23.2 & & 23.6 & 26.3 & & 27 & & 27.3 & & & 22.6 & & & \\
\hline & 21.2 & & 24.7 & & 22.1 & & 21.8 & 28.5 & & 27.7 & & 28.2 & & & & & & \\
\hline & 17.4 & & 20.7 & & 24.5 & & & 25.3 & & 24.6 & & 25 & & & & & & \\
\hline & 20.2 & & 23.7 & & 26.3 & & & 23.6 & & 30.4 & & 27.9 & & & & & & \\
\hline & 17.6 & & 13.6 & & 23.6 & & & 24 & & 26.1 & & 26.7 & & & & & & \\
\hline & 19.5 & & 22.5 & & 20.6 & & & 23.1 & & 26.6 & & 21.5 & & & & & & \\
\hline & 22 & & 23.3 & & 25.8 & & & 23.7 & & 24.1 & & 28.1 & & & & & & \\
\hline & 21.2 & & 24.3 & & 26.2 & & & 24 & & 25.4 & & 32.9 & & & & & & \\
\hline & 20 & & 24.5 & & 23.7 & & & 25.3 & & 24.7 & & 29.8 & & & & & & \\
\hline & 21.1 & & 23.7 & & 26.7 & & & 26 & & 24.8 & & 27.4 & & & & & & \\
\hline & 17.1 & & 23.6 & & 25.2 & & & 24.5 & & 25.1 & & 28.8 & & & & & & \\
\hline & 19 & & & & 21.4 & & & 24.9 & & 26.2 & & 28.3 & & & & & & \\
\hline & 19.6 & & & & 23.5 & & & 26.5 & & 28.9 & & 28.4 & & & & & & \\
\hline
\end{tabular}


Table B.12. Fish Sampling

\begin{tabular}{|c|c|c|c|c|c|c|c|c|c|c|c|c|c|c|c|c|}
\hline \multicolumn{17}{|l|}{ B2 } \\
\hline Sample Date & \multicolumn{2}{|c|}{$10 / 14 / 2003$} & \multicolumn{2}{|c|}{$11 / 17 / 2003$} & \multicolumn{2}{|c|}{$12 / 18 / 2003$} & \multicolumn{2}{|c|}{$1 / 20 / 2004$} & \multicolumn{2}{|c|}{ 2/19/2004 } & \multicolumn{2}{|c|}{$3 / 22 / 2004$} & \multicolumn{2}{|c|}{ 4/23/2004 } & \multicolumn{2}{|c|}{$5 / 24 / 2004$} \\
\hline \# Fish & \multicolumn{2}{|c|}{53} & 31 & 24 & \multicolumn{2}{|c|}{59} & 27 & 41 & 40 & 23 & \multicolumn{2}{|c|}{56} & \multicolumn{2}{|c|}{50} & 42 & 19 \\
\hline wt (kg) & \multicolumn{2}{|c|}{4.72} & 4.78 & 3.62 & \multicolumn{2}{|c|}{11.22} & 6.48 & 9.58 & 9.58 & 5.08 & \multicolumn{2}{|c|}{15.62} & & & 17.06 & 8.18 \\
\hline Avg (g/fish) & & & 154 & 151 & & & 240 & 234 & 240 & 221 & & & & & 406 & 431 \\
\hline & lengt & (cm) & lengt & (cm) & leng & (cm) & leng & (cm) & leng & (cm) & leng & (cm) & leng & $(\mathrm{cm})$ & lengtl & (cm) \\
\hline & 20 & 21.2 & 22.5 & 24.6 & 22.1 & 23.1 & 26 & 25.2 & 25.2 & 25.7 & 27.5 & 28.8 & 31.2 & 28.8 & 38.6 & 30 \\
\hline & 20.8 & 19.9 & 21.5 & 23.3 & 26.1 & 27.1 & 29.2 & 30 & 27.1 & 22.6 & 27.6 & 26.6 & 32.3 & 28 & 37.8 & 35.4 \\
\hline & 21.3 & 17.5 & 24.7 & 24.9 & 24 & 24.6 & 24 & 26.5 & 25.4 & 26.4 & 31.6 & 27.4 & 27.2 & 30 & 36.1 & 36.4 \\
\hline & 20.6 & 20 & 20.6 & 19.9 & 22.6 & 27 & 25.2 & 29.1 & 24.1 & 23.6 & 27.1 & 27 & 26.5 & 28.6 & 34.6 & 33.9 \\
\hline & 18.5 & 20 & 21.3 & 24 & 26.3 & 22.1 & 25.9 & 28.1 & 24.6 & 26.1 & 30.5 & 29.8 & 30.6 & 21.3 & 35.2 & 28.7 \\
\hline & 21 & 17.9 & 20.7 & 24.5 & 25.2 & 24.6 & 27 & 28.3 & 25.2 & 20.7 & 28.4 & 28.6 & 30.5 & 29.3 & 31.5 & 36.2 \\
\hline & 21.5 & 18 & 20.4 & 25.5 & 21.8 & 23.2 & 25.2 & 27.2 & 26.5 & 23.3 & 27.5 & 29.5 & 31.1 & & 34.6 & 34.2 \\
\hline & 17.3 & 21.3 & 22.9 & 21.9 & 22.3 & 23.9 & 26.3 & 31.2 & 31.3 & 22.5 & 29.6 & 26.2 & 31.3 & & 24.7 & 33 \\
\hline & 19 & 21.3 & 24.5 & 21 & 24.7 & 23.5 & 25 & 25.6 & 27.6 & 30.4 & 29 & 31.3 & 21.1 & & 35.6 & 33.1 \\
\hline & 21.3 & & 24.6 & 21.4 & 27.1 & 24 & 28.5 & 23.9 & 22.5 & 28.4 & 25.6 & 27.7 & 32.2 & & 27.8 & 32.6 \\
\hline & 20.2 & & 22.3 & 22.6 & 28.5 & 25.2 & 29.5 & 27.6 & 27 & 22.7 & 22.6 & 25.5 & 29.2 & & 29.7 & 33.2 \\
\hline & 22.1 & & 22.7 & 22 & 24.2 & 21.8 & 30.1 & 28.3 & 25.5 & 28.3 & 32.2 & 30.8 & 26.5 & & 31.2 & 27.1 \\
\hline & 22.8 & & 25.2 & 22 & 23.2 & 22.1 & 25.6 & 25.8 & 29 & 27.7 & 27.8 & & 29.3 & & 28.4 & 34.3 \\
\hline & 23 & & 22.9 & 22.2 & 26.3 & 23.4 & 28 & 26.6 & 27.8 & 28 & 27.1 & & 30.4 & & 29.2 & 28.7 \\
\hline & 18.7 & & 22.3 & 23.2 & 25.2 & 23.7 & 25.1 & 26.7 & 27.4 & 28.9 & 27.4 & & 25.7 & & 25.1 & 31.2 \\
\hline & 17 & & 22 & 24.3 & 22.2 & 23.5 & 28 & 28 & 27.6 & 27.8 & 30 & & 28.8 & & 29.3 & 27.7 \\
\hline & 23.8 & & 18.9 & 21.2 & 24.2 & & 28 & 29 & 25.6 & 26.1 & 27.7 & & 29.4 & & 31.6 & 30.6 \\
\hline & 20.3 & & 24.7 & 22.5 & 24.7 & & 27.3 & 27 & 31.8 & 27.6 & 30.2 & & 30.5 & & 31.7 & 27.5 \\
\hline & 20.6 & & 23.5 & 20.2 & 24.4 & & 29 & 24.9 & 27.8 & 23.5 & 28.9 & & 27.1 & & 31 & 30 \\
\hline & 20.5 & & 21 & 21.2 & 25.2 & & 26.5 & 24.7 & 25.8 & 23.8 & 24.7 & & 24 & & 30.2 & \\
\hline & 20.5 & & 23.7 & 23.4 & 26.6 & & 24 & 23.2 & 27.9 & 28.4 & 31.7 & & 28.3 & & 31.3 & \\
\hline & 21.5 & & 24.3 & 22 & 25.5 & & 23.2 & 22 & 27.8 & 25.6 & 28.3 & & 26.3 & & 29.7 & \\
\hline & 20.8 & & 22.7 & 22.9 & 25.5 & & 23.4 & 26.8 & 25.1 & 24.1 & 25.9 & & 31.5 & & 34.5 & \\
\hline & 18.3 & & 27.6 & 23 & 22.7 & & 22 & 26.3 & 30.4 & & 25.6 & & 33.2 & & 32.4 & \\
\hline & 18.7 & & 23.1 & & 23.6 & & 26 & 27.2 & 26 & & 27.6 & & 31 & & 32.9 & \\
\hline & 21.2 & & 22.5 & & 25.6 & & 26.1 & 24 & 27.4 & & 27.1 & & 32.6 & & 28.7 & \\
\hline & 20.3 & & 21 & & 26.7 & & 26.8 & 26.3 & 19.8 & & 29.5 & & 33.3 & & 29.5 & \\
\hline & 17.6 & & 23.5 & & 27.6 & & 26.5 & 25 & 26.5 & & 26.7 & & 25.1 & & 35.1 & \\
\hline & 22.2 & & 22.7 & & 25.8 & & & 27.3 & 24.4 & & 27.5 & & 33.2 & & 29.1 & \\
\hline & 19.3 & & 20.5 & & 22.9 & & & 25 & 29.7 & & 27.1 & & 36.1 & & 32.3 & \\
\hline & 21.2 & & 23.2 & & 22.7 & & & 25.3 & 25.1 & & 27.3 & & 30.6 & & 28.5 & \\
\hline & 17.4 & & & & 23.5 & & & 23.9 & 26.6 & & 26.6 & & 33.4 & & 29.2 & \\
\hline & 20.2 & & & & 26.8 & & & 27.1 & 24.5 & & 27.4 & & 30.3 & & 28.5 & \\
\hline & 17.6 & & & & 24.3 & & & 26.4 & 30.6 & & 28.5 & & 31 & & 33.6 & \\
\hline & 19.5 & & & & 24.3 & & & 27.2 & 29.4 & & 30.3 & & 29.2 & & 27.1 & \\
\hline & 22 & & & & 21.6 & & & 24.5 & 26.2 & & 30.4 & & 30.1 & & 32.7 & \\
\hline & 21.2 & & & & 22.6 & & & 26.4 & 25.8 & & 24.6 & & 30 & & 30.6 & \\
\hline & 20 & & & & 23.2 & & & 26.2 & 27.3 & & 26.1 & & 28.7 & & 34.7 & \\
\hline & 21.1 & & & & 27.1 & & & 27.6 & 27.2 & & 27 & & 28.7 & & 32.6 & \\
\hline & 17.1 & & & & 22.1 & & & 24.9 & 28.6 & & 27.3 & & 25.8 & & 33.5 & \\
\hline & 19 & & & & 21.6 & & & 28.6 & & & 28.4 & & 28.6 & & 25.1 & \\
\hline & 19.6 & & & & 17 & & & 22.4 & & & 30.1 & & 29.3 & & 32.5 & \\
\hline & 20.4 & & & & 22.6 & & & & & & 27.4 & & 26.1 & & & \\
\hline & 18.5 & & & & 23.1 & & & & & & 28.6 & & 31.1 & & & \\
\hline
\end{tabular}


Table B.12. Fish Sampling

\begin{tabular}{|c|c|c|c|c|c|c|c|c|c|c|c|c|c|c|c|c|}
\hline \multicolumn{17}{|l|}{ B3 } \\
\hline \multirow{2}{*}{$\begin{array}{r}\text { Sample Date } \\
\text { \# Fish }\end{array}$} & \multicolumn{2}{|c|}{$10 / 14 / 2003$} & \multicolumn{2}{|c|}{$1 / 17 / 2003$} & \multirow{2}{*}{\multicolumn{2}{|c|}{$\begin{array}{c}12 / 18 / 2003 \\
64\end{array}$}} & \multicolumn{2}{|c|}{$1 / 20 / 2004$} & \multicolumn{2}{|c|}{ 2/19/2004 } & \multirow{2}{*}{\multicolumn{2}{|c|}{$\begin{array}{c}3 / 22 / 2004 \\
51\end{array}$}} & \multirow{2}{*}{\multicolumn{2}{|c|}{$\begin{array}{c}4 / 23 / 2004 \\
56 \\
\end{array}$}} & \multicolumn{2}{|c|}{$5 / 24 / 2004$} \\
\hline & \multicolumn{2}{|c|}{53} & 41 & 23 & & & 42 & 17 & 48 & 17 & & & & & 23 & 27 \\
\hline wt (kg) & \multicolumn{2}{|c|}{4.72} & 6.28 & 3.34 & \multicolumn{2}{|c|}{12.06} & 8.64 & 4.24 & 11.56 & 4.22 & \multicolumn{2}{|c|}{15.14} & \multicolumn{2}{|c|}{23} & 10.38 & 12.94 \\
\hline Avg (g/fish) & & & 153 & 145 & & & 206 & 249 & 241 & 248 & & & & & 451 & 479 \\
\hline & lengt & $(\mathrm{cm})$ & lengt & $(\mathrm{cm})$ & leng & $(\mathrm{cm})$ & leng & $(\mathrm{cm})$ & lengt & $(\mathrm{cm})$ & leng & $(\mathrm{cm})$ & leng & $(\mathrm{cm})$ & lengt & $(\mathrm{cm})$ \\
\hline & 20 & 19.9 & 19.6 & 22.6 & 27 & 25.2 & 25.6 & 26 & 26.6 & 23 & 28.9 & 29 & 32.1 & 30.1 & 31.6 & 36.6 \\
\hline & 20.8 & 17.5 & 21.3 & 23.8 & 26.8 & 25.5 & 26.4 & 27.8 & 26.9 & 23.2 & 26.6 & 30.9 & 26 & 31.5 & 35.7 & 29.1 \\
\hline & 21.3 & 20 & 22.5 & 24.3 & 26.1 & 25.2 & 26.6 & 28.9 & 20.1 & 26.5 & 29.7 & 28.8 & 28.6 & 33 & 33.8 & 34 \\
\hline & 20.6 & 20 & 24.1 & 23.7 & 25.2 & 24 & 26 & 23.8 & 27.5 & 26.1 & 29.8 & 26.6 & 31.3 & 32.1 & 34.3 & 36.1 \\
\hline & 18.5 & 17.9 & 18.6 & 20.3 & 25.1 & 25.1 & 23.7 & 27.6 & 21.3 & 28.5 & 27.8 & 29.2 & 28.9 & 30.7 & 29.5 & 34.4 \\
\hline & 21 & 18 & 24.2 & 23.2 & 24.6 & 24.9 & 26.3 & 26.2 & 25.6 & 27.3 & 29.4 & 29.8 & 29.1 & 28.5 & 29.6 & 33.6 \\
\hline & 21.5 & 21.3 & 24.8 & 19.7 & 26 & 25.9 & 24.5 & 27.4 & 25.2 & 25.4 & 25.6 & & 31.2 & 31.2 & 27.2 & 34.2 \\
\hline & 17.3 & 21.3 & 25.1 & 24.2 & 23.6 & 23.3 & 25.7 & 25.5 & 31 & 29.3 & 26.2 & & 27.1 & 27.4 & 35.2 & 38.4 \\
\hline & 19 & & 21.7 & 18.3 & 26 & 23.2 & 26.2 & 28.4 & 29.1 & 29.2 & 28.3 & & 28.8 & 30.5 & 32.3 & 34.8 \\
\hline & 21.3 & & 23.5 & 22.5 & 26.8 & 22 & 27.1 & 28 & 24.2 & 28.7 & 29.3 & & 28.6 & 32 & 36.1 & 33.2 \\
\hline & 20.2 & & 21.2 & 19.8 & 25.4 & 18.9 & 24.2 & 28.7 & 28 & 30.9 & 27.5 & & 31.7 & 32.1 & 31.2 & 32 \\
\hline & 22.1 & & 23.7 & 21.9 & 24.1 & 22.2 & 25.2 & 26 & 27.8 & 27.4 & 28 & & 33.2 & & 32.8 & 32.8 \\
\hline & 22.8 & & 24.5 & 23.6 & 26.6 & 15.1 & 25.1 & 27 & 26.1 & 24.3 & 28.6 & & 29.7 & & 32.1 & 30 \\
\hline & 23 & & 21 & 24.5 & 25.4 & 23.5 & 24.6 & 27.6 & 26.2 & 27.8 & 30.2 & & 31.5 & & 34.6 & 36.1 \\
\hline & 18.7 & & 22 & 20.7 & 26.3 & 25.6 & 27.9 & 28 & 27.2 & 28.6 & 28.6 & & 32.6 & & 27 & 31 \\
\hline & 17 & & 23.6 & 24.2 & 19.8 & 22.1 & 26.5 & 30.1 & 25.9 & 22.5 & 27.7 & & 32.3 & & 32.7 & 28 \\
\hline & 23.8 & & 23.8 & 23 & 25.2 & 21.3 & 27.8 & 25 & 28 & 24.9 & 28.2 & & 33.1 & & 31.5 & 35.7 \\
\hline & 20.3 & & 23.4 & 19.2 & 27.1 & 21.1 & 27.3 & 25 & 28.4 & & 29 & & 26.4 & & 23.3 & 34.7 \\
\hline & 20.6 & & 21 & 21 & 23.5 & 22.6 & 23.5 & & 27.5 & 31 & 28.1 & & 26.3 & & 33.3 & 32.8 \\
\hline & 20.5 & & 21.5 & 23.8 & 23.2 & 23.3 & 25.4 & & 27.1 & 25.1 & 29.6 & & 24.9 & & 29 & 35.4 \\
\hline & 20.5 & & 17.2 & 22.2 & 22 & & 26.1 & & 26.8 & 27.6 & 28.6 & & 32.1 & & 31.7 & 32 \\
\hline & 21.5 & & 24 & 18.4 & 21.2 & & 26.5 & & 28.6 & & 28.2 & & 31.3 & & 32 & 31.8 \\
\hline & 20.8 & & 23 & 22.5 & 25.6 & & 25.4 & & 28.4 & & 26.7 & & 34.7 & & 36.2 & 33 \\
\hline & 18.3 & & 21.9 & & 23.3 & & 27.5 & & 26.4 & & 29.8 & & 32.1 & & & 33.8 \\
\hline & 18.7 & & 23.4 & & 23.5 & & 24.4 & & 24.5 & & 25.6 & & 33 & & & 31.7 \\
\hline & 21.2 & & 21.9 & & 24.2 & & 21.6 & & 26.4 & & 29.2 & & 31.8 & & & 29.3 \\
\hline & 20.3 & & 26 & & 24.1 & & 26.8 & & 26.8 & & 30.1 & & 31.6 & & & 29.8 \\
\hline & 17.6 & & 24.2 & & 27 & & 23.2 & & 28.4 & & 30.4 & & 25.4 & & & \\
\hline & 22.2 & & 23.8 & & 24.6 & & 28.4 & & 24.1 & & 29.5 & & 30.6 & & & \\
\hline & 19.3 & & 21 & & 24.5 & & 23.9 & & 24.9 & & 26.5 & & 24.7 & & & \\
\hline & 21.2 & & 23.8 & & 23.2 & & 25.3 & & 25.3 & & 27.2 & & 29.6 & & & \\
\hline & 17.4 & & 25.2 & & 24 & & 27 & & 27.1 & & 31.5 & & 31.5 & & & \\
\hline & 20.2 & & 22.2 & & 23.9 & & 24.6 & & 26.3 & & 28 & & 31.7 & & & \\
\hline & 17.6 & & 21.8 & & 23.8 & & 27.4 & & 27.2 & & 27.1 & & 32.6 & & & \\
\hline & 19.5 & & 23.2 & & 23.1 & & 20.9 & & 26.4 & & 28.7 & & 30.4 & & & \\
\hline & 22 & & 21.1 & & 23.3 & & 22.5 & & 27.5 & & 26.8 & & 32.5 & & & \\
\hline & 21.2 & & 20.4 & & 22.8 & & 24.5 & & 28.5 & & 27.6 & & 31 & & & \\
\hline & 20 & & 23 & & 27.4 & & 27.5 & & 26.6 & & 26 & & 32.1 & & & \\
\hline & 21.1 & & 20 & & 28.5 & & 23.6 & & 24.3 & & 28 & & 30.1 & & & \\
\hline & 17.1 & & 25.5 & & 23.6 & & 25.2 & & 25.8 & & 30.3 & & 32.2 & & & \\
\hline & 19 & & 20.6 & & 23.7 & & 26.5 & & 26.4 & & 28.5 & & 31.5 & & & \\
\hline & 19.6 & & & & 24.5 & & 27.6 & & 25 & & 26.7 & & 34.1 & & & \\
\hline & 20.4 & & & & 25.7 & & 25.2 & & 24.5 & & 24.1 & & 30.6 & & & \\
\hline & 18.5 & & & & 25.1 & & & & 29.1 & & 31.6 & & 31 & & & \\
\hline & 21.2 & & & & 25.2 & & & & 28.1 & & 29.2 & & 32 & & & \\
\hline
\end{tabular}


Table B.13. Aquasludge

\begin{tabular}{|c|c|c|c|c|c|c|c|c|}
\hline A3 & \multicolumn{1}{|c|}{} \\
\hline Date & $\begin{array}{c}\text { Vol } \\
(\mathbf{L})\end{array}$ & $\begin{array}{c}\text { TSS } \\
(\mathbf{m g} / \mathbf{L})\end{array}$ & $\begin{array}{c}\text { TS } \\
(\mathbf{m g} / \mathbf{L})\end{array}$ & $\begin{array}{c}\mathbf{N O}_{\mathbf{2}} \\
(\mathbf{m g} / \mathbf{L})\end{array}$ & $\begin{array}{c}\mathbf{N O}_{3} \\
(\mathbf{m g} / \mathbf{L})\end{array}$ & $\begin{array}{c}\text { TAN } \\
(\mathbf{m g} / \mathbf{L})\end{array}$ & $\begin{array}{c}\text { TP } \\
(\mathbf{m g} / \mathbf{L})\end{array}$ & $\begin{array}{c}\mathbf{B O D}_{5} \\
(\mathbf{m g} / \mathbf{L})\end{array}$ \\
\hline $11 / 10 / 2003$ & 189 & 1747 & 7219 & 0.04 & 0.12 & 5.08 & 56.4 & 1629 \\
\hline $12 / 8 / 2003$ & 238 & 4380 & 10425 & & & & & 2263 \\
\hline $1 / 28 / 2004$ & 79 & 4875 & 10936 & $<0.02$ & 0.15 & 8.13 & 34.9 & 1582 \\
\hline $2 / 11 / 2004$ & 163 & 4470 & 9898 & & & & & 1702 \\
\hline
\end{tabular}

\begin{tabular}{|c|c|c|c|c|c|c|c|c|}
\hline \multicolumn{1}{|l|}{ B3 } \\
\hline Date & $\begin{array}{c}\text { Vol } \\
(\mathbf{L})\end{array}$ & $\begin{array}{c}\text { TSS } \\
(\mathbf{m g} / \mathbf{L})\end{array}$ & $\begin{array}{l}\text { TS } \\
(\mathbf{m g} / \mathbf{L})\end{array}$ & $\begin{array}{c}\mathbf{N O}_{\mathbf{2}} \\
(\mathbf{m g} / \mathbf{L})\end{array}$ & $\begin{array}{c}\mathbf{N O}_{3} \\
(\mathbf{m g} / \mathbf{L})\end{array}$ & $\begin{array}{c}\text { TAN } \\
(\mathbf{m g} / \mathbf{L})\end{array}$ & $\begin{array}{c}\text { TP } \\
(\mathbf{m g} / \mathbf{L})\end{array}$ & $\begin{array}{c}\mathbf{B O D}_{5} \\
(\mathbf{m g} / \mathbf{L})\end{array}$ \\
\hline $11 / 10 / 2003$ & 159 & 1140 & 6898 & 0.02 & 0.14 & 2.9 & 30.2 & 925 \\
\hline $12 / 8 / 2003$ & 201 & 2158 & 7488 & & & & & 1157 \\
\hline $1 / 28 / 2004$ & 70 & 1150 & 6978 & $<0.02$ & 0.12 & 4.81 & 15.1 & 819 \\
\hline $2 / 11 / 2004$ & 125 & 3070 & 9013 & & & & & 1430 \\
\hline
\end{tabular}




\section{APPENDIX C - Aeromonas Report}

\section{West Virginia Department of Agriculture \\ Gus R. Douglass, Commissioner \\ Animal Health Division}

Diagnostic Laboratory

1900 Kanawha Boulevard, East

Charleston, West Virginia 25305-0172

CULTURE REPORT

(304) 558-2214

\begin{tabular}{|l|l|l|l|}
$\begin{array}{l}\text { Owner } \\
\text { Address }\end{array}$ & WVU & $\begin{array}{l}\text { Veterinarian } \\
\text { Clinic } \\
\text { Address }\end{array}$ & $\begin{array}{l}\text { Dr. Kenneth Semmens } \\
\text { West Virginia University } \\
\text { P.O. Box 6108 } \\
\text { Morgantown, WV } \\
\text { 26506-6108 }\end{array}$ \\
\hline \hline Sample Identification: Lesion and swim bladder cultures (4) from two fish \\
\hline \hline Date rcvd: $03-31-03$ & Accession No: A-04-72 & Species: (fish) \\
\hline \hline Breed: trout & Age: & Sex: \\
\hline \hline History: external lesions with cavities; gills contained no visual parasites
\end{tabular}

\section{FINAL REPORT}

$$
S=\text { SENSITIVE } \quad R=\text { RESISTANT } \quad I=I N T E R M E D I A T E
$$

\section{LESION \& SWIM BLADDER:}

Aeromonas salmonicida ss salmonicida - moderate growth

Oxytetracycline

Neomycin

$\mathrm{R}$

$\mathrm{S}$

Gentamicin

Chloramphenicol

S

S

\section{LESION:}

Aeromonas sobria - moderate growth

Oxytetracycline

Neomycin

$\mathrm{S}$

S

Pseudomonas - moderate growth

Oxytetracycline

Neomycin

\section{$\mathrm{S}$}

S
Gentamicin

Chloramphenicol

Gentamicin

Chloramphenicol
S

S

S

$\mathrm{R}$ 